\title{
Ceria-Based Catalysts Studied by Near Ambient Pressure X-ray Photoelectron Spectroscopy: A Review
}

\author{
Xènia Garcia ${ }^{1,2}{ }^{\circledR}$, Lluís Soler ${ }^{1}{ }^{(0}$, Núria J. Divins ${ }^{1}$, Xavier Vendrell ${ }^{1}{ }^{\circledR}$, Isabel Serrano ${ }^{1}(\mathbb{D}$, \\ Ilaria Lucentini ${ }^{1}$, Jordi Prat ${ }^{2}$, Eduardo Solano ${ }^{2}$ (), Massimo Tallarida ${ }^{2}$, Carlos Escudero ${ }^{2, *(1)}$ and \\ Jordi Llorca ${ }^{1, *(1)}$
}

1 Institute of Energy Technologies, Department of Chemical Engineering and Barcelona Research Center in Multiscale Science and Engineering, Universitat Politècnica de Catalunya, Escola d'Enginyeria de Barcelona Est (EEBE), Eduard Maristany 10-14, 08019 Barcelona, Spain; xenia.garcia.de.andres@upc.edu (X.G.); lluis.soler.turu@upc.edu (L.S.); nuria.jimenez.divins@upc.edu (N.J.D.); xavier.vendrell.villafruela@upc.edu (X.V.); isabel.serrano@upc.edu (I.S.); ilaria.lucentini@upc.edu (I.L.)

2 ALBA Synchrotron Light Source, Carrer de la Llum 2-26, Cerdanyola del Vallès, 08290 Barcelona, Spain; jprat@cells.es (J.P.); esolano@cells.es (E.S.); mtallarida@cells.es (M.T.)

* Correspondence: cescudero@cells.es (C.E.); jordi.llorca@upc.edu (J.L.); Tel.: +34935924372 (C.E.); +34934011708 (J.L.)

Received: 4 February 2020; Accepted: 1 March 2020; Published: 3 March 2020

\begin{abstract}
The development of better catalysts is a passionate topic at the forefront of modern science, where operando techniques are necessary to identify the nature of the active sites. The surface of a solid catalyst is dynamic and dependent on the reaction environment and, therefore, the catalytic active sites may only be formed under specific reaction conditions and may not be stable either in air or under high vacuum conditions. The identification of the active sites and the understanding of their behaviour are essential information towards a rational catalyst design. One of the most powerful operando techniques for the study of active sites is near ambient pressure X-ray photoelectron spectroscopy (NAP-XPS), which is particularly sensitive to the surface and sub-surface of solids. Here we review the use of NAP-XPS for the study of ceria-based catalysts, widely used in a large number of industrial processes due to their excellent oxygen storage capacity and well-established redox properties.
\end{abstract}

Keywords: ceria; catalysis; X-ray photoelectron spectroscopy; photoemission; NAP-XPS; AP-XPS; APPES

\section{Ceria in Catalysis}

Ceria-based catalysts have been widely investigated in the last decades for different applications. They include nanoshaped ceria, ceria mixed metal oxides and transition metals supported on ceria. In addition to its well-established use as an active component of catalytic converters for the treatment of exhaust gases, ceria-based catalysts have also been developed for soot abatement, VOC combustion, reforming processes, water-gas shift, methane activation, acid-base chemistry and organic chemistry reactions, among others. An excellent level of fundamental knowledge has been attained over the years, which has been compiled in a large number of seminal reviews [1-6].

Ceria displays an extraordinary oxygen storage capacity (OSC) and redox properties because it has the ability to accommodate a large number of oxygen vacancies under a slightly reducing atmosphere to give under-stoichiometric $\mathrm{CeO}_{2-x}$, which can be oxidised back to $\mathrm{CeO}_{2}$ in an oxygen-containing atmosphere. This occurs without structural modification of the fluorite ceria lattice and is not limited to the surface, but also takes place in the bulk $[7,8]$. Surface science studies on thin layers of ceria with controlled terminations and studies performed on nanoshaped ceria (rods, cubes, wires, tubes and spheres) 
demonstrate that the formation of an oxygen vacancy on ceria is strongly surface sensitive and that the redox reactivity of ceria depends on the crystallographic planes exposed [9-12]. The $\{111\}$ is the thermodynamically most stable termination, followed by the $\{110\}$ and the least stable $\{100\}[13,14]$. However, surface reconstruction, surface roughening and creation of defects commonly occur to lower the surface energy [15]. Vacancies play an active role in the oxygen storage process and represent mobile reactive sites which can act as centres for oxygen activation in oxidation reactions [16]. The $\{111\}$ surface is the most compact and less prone to accommodate a vacancy defect and the order of reactivity for the vacancy formation follows the trend $\{110\}>\{100\}>\{111\}$ [17]. The precise control of surface atomic arrangements in ceria can modify the reactivity of $\mathrm{Ce}^{4+} / \mathrm{Ce}^{3+}$ ions and change the oxygen release/uptake characteristics, which, in turn, are closely tied with its catalytic properties [18]. In particular, oxidation reactions over $\mathrm{CeO}_{2}$ are believed to proceed through the Mars-van Krevelen mechanism, where the reactant first reacts with surface ceria oxygen leaving an oxygen vacancy, which is then filled with gas phase oxygen.

In addition to the importance of the exposed planes, the other key parameter that modifies the surface chemistry of ceria is particle size. The smaller the ceria particle size the larger the reduction of the valence of $\mathrm{Ce}$ from +4 to +3 , which implies a correlation between oxygen vacancy concentration and ceria crystal size. This is particularly evident in ceria crystallites below $5 \mathrm{~nm}$ [19-22]. In this case, $\mathrm{Ce}^{3+}$ sites are not necessarily associated to an oxygen vacancy and can act as a centre for adsorption of oxygen to yield active oxygen species and thus boosting oxygen storage activity and low-temperature oxidation activity [23-26]. There is a consensus that the preparation of active ceria-based catalysts requires the presence of defective surface sites, either $\mathrm{Ce}^{3+}$ or $\mathrm{Ce}^{4+}$ associated with a vacancy, which can act as centres to maximize active oxygen adsorption/release under operative conditions. Nevertheless, the way to accomplish this and the associated mechanism is not yet completely known. For instance, the structure of these defects plays also an important role in catalysis, being larger oxygen vacancy clusters preferable $[27,28]$.

Regarding the role of ceria as a support, it is remarkable how it can strongly modify the reactivity of supported metal nanoparticles [29-31] and also protect metal nanoparticles from sintering at high temperature [32], or even stabilize metals as single atoms [33]. The unique properties of ceria, such as the availability of surface oxygen species which ceria can supply to those metal atoms located at the interface perimeter [34,35], makes it an excellent support for a wide number of catalytic applications [36]. From the study of inverse structures, where ceria nanoparticles are deposited on selected metal films, the metal- $\mathrm{CeO}_{2}$ interface has unambiguously been identified as the catalytic active site in many reactions [37]. The mechanism of oxygen transfer between ceria and the metal is responsible for the enhancement of activity and, again, it is strongly dependent on the morphology and the size of the ceria particles [38-40]. The surface terminations of $\mathrm{CeO}_{2}$ can also influence the size, morphology and interface of the metal nanoparticles that, furthermore, can change under different reaction environments. These factors are interdependent and originate complex systems. As expected, the electronic state of the deposited metal nanoparticles strongly depends on the reduction degree of the ceria support and, in particular, by the presence of oxygen vacancies in areas underneath the metal [41,42]. Interestingly, the presence of metal nanoparticles on top of ceria crystallites in turn strongly modifies the reducibility of the underlying cerium oxide. Obviously, this synergy has an impact on the catalytic behaviour and the use of operando characterization techniques turns out to be invaluable and necessary to decipher the nature of the metal-ceria interface, which remains a controversial issue in most cases.

In this review, we focus on the use of near ambient pressure X-ray photoelectron spectroscopy (NAP-XPS) to study the surface and subsurface arrangements in ceria-based catalysts. In addition, their dynamic behaviour under operation conditions to ultimately obtain structure-activity relationships will also be revised.

\section{Near Ambient Pressure XPS}

X-ray photoelectron spectroscopy (XPS) has been widely used in heterogeneous catalysis as one of the most powerful techniques to yield information on the chemical composition and electronic 
configuration of the different elements present on the surface of the materials studied. This tool, developed in the late 1950s by K. Siegbahn and co-workers $[43,44]$, had a great impact on surface science and other related scientific fields and allowed K. Siegbahn to win the Nobel Prize in Physics in 1981. In heterogeneous catalysis, the surface of the catalysts is in direct contact with the reactants, gases or liquids. Therefore, the potential of XPS is obvious, as a surface-sensitive technique with a probing depth that can be tuned, depending on the excitation energy used, down to a few atomic layers. However, XPS has been traditionally performed under high vacuum or ultra-high vacuum environments due to the strong interaction of the photoelectrons ejected with liquid and gas phase molecules. In this way, many instruments working under this pressure regime using conventional $\mathrm{x}$-ray sources or synchrotron light can be found in many laboratories and synchrotrons around the world and XPS has become a routine analysis technique in many laboratories and industries. Since this pressure regime is far from the one applied in heterogeneous catalytic reactions, the catalyst characterization by XPS is usually done before and after its exposure to the reaction conditions in a high-pressure cell. Nevertheless, it has been demonstrated that in some cases the catalysts exhibit dramatic differences when exposed to the reaction environment. This fact explains the many efforts made to minimize the so-called pressure gap in different spectroscopic techniques [45-47]. Indeed, K. Siegbahn was pioneering also the XPS operation under more realistic environments and, by the implementation of a differential pumping system, he was able to acquire the first gas phase spectra [48]. Furthermore, together with his son, H. Siegbahn, they started to apply the XPS technique to study liquids [49]. During the next decades, there were several improvements to overcome the constraints to use XPS under higher gas pressures [50] but the implementation of an electrostatic lens system that focused the photoelectrons in the apertures of the differential pumping system [51] was the key that led to the establishment of the ambient pressure photoelectron spectroscopy (APPES) technique, also called ambient pressure or near ambient pressure X-ray photoelectron spectroscopy (AP-XPS or NAP-XPS). In the beginning, the NAP-XPS technique was found only in synchrotron facilities [52] (e.g., ALS, BESSY) but during the last two decades it has become a commercially available technique and lab-based instruments with different configurations are also spreading worldwide [53].

The application of NAP-XPS in heterogeneous catalysis has opened new possibilities and a large number of reviews and book chapters have appeared in the last years [50,52-65]. NAP-XPS has been used within this field to study from single crystals and model metal-oxide systems $[35,55,58,60,66]$ to more realistic mono- and bimetallic unsupported nanocatalysts and metal-oxide complex systems [57]. For the particular case of bimetallic catalysts, the combination of NAP-XPS with synchrotron radiation allows following the segregation of the different metals under reaction conditions [67], i.e., the excitation energy can be tuned and therefore it is possible to detect photoelectrons ejected from different depths of the sample without destroying it. Furthermore, this technique has clarified that these changes on the metals distribution in bimetallic particles not only depend on the reaction environment, but also on the oxide support [68] and even its shape [69]. NAP-XPS, due to its capabilities, is one of the most demanded tools for heterogeneous catalytic studies; however, there are of course other issues to be considered when applying this technique, e.g., beam damage or contamination issues among others. The first one can be assessed to some extent by minimizing the sample exposure to the $\mathrm{X}$-rays (by moving to fresh sample spot, decreasing the acquisition time or decreasing in another way the photon flux) and the second one constitutes one of the main drawbacks related to this powerful tool and sometimes requires the use of plasma cleaning procedures.

On the other hand, the potential of NAP-XPS to study electrocatalytic systems under operando conditions has experienced a big step in the last few years with the development of new instrumentation for both solid-liquid and solid-gas interfaces [70-74]. Indeed, the first experiments related to solid-oxide fuel cells (SOFC) studied by means of NAP-XPS were performed on ceria based systems [75].

As stated before, the applications and potential of the NAP-XPS technique have increased substantially in the last years and, as a consequence, the number of related publications has evolved exponentially, including different reviews. However, in this particular case and for the first time, 
all the literature related to heterogeneous catalysis and electrocatalysis research focused on ceria-based systems and studied by means of NAP-XPS has been summarized up-to-date. This contribution aims to be a reference to guide future studies in these fields using this powerful technique for a better understanding of the properties of ceria, which will allow designing better catalysts.

\section{Examples for the Application of NAP-XPS to Ceria Catalysts}

As explained above, the application of NAP-XPS in catalysis science has recently received great interest since it allows the study of real and model catalytic systems, as well as electrochemical devices, during the reaction. This surface-sensitive technique can provide information on catalysts' chemical state and surface composition under a wide range of environmental conditions, including reactant and product gas phase molecules in the vicinity of the surface. Additionally, depth profiling studies are viable by tuning the photon energy in synchrotron sources, which can be used to examine migration of species into the catalyst surface/subsurface and to relate them with changes on reactivity.

In this review, we have gathered to the best of our knowledge all the peer-reviewed reports on cerium oxide performed using the NAP-XPS technique. All the examples included, performed under a wide range of experimental conditions (e.g., temperature, pressure, gas composition, electrical bias), are studies of gas-solid interfaces and have been classified into three well distinctive blocks: a first block of reports based on studies of the properties of cerium oxide itself, a second block which includes all the investigations of ceria-based catalysts for gas-solid reactions and a third and last block of studies of gas-solid electrocatalytic reactions, most of them based on solid oxide fuel cell systems with ceria as a component.

\subsection{Fundamental Studies}

As discussed in the introduction, one of the properties that makes cerium oxide such an excellent catalyst is its well-known OSC $[36,76]$. Therefore, in order to improve the activity of ceria-based catalysts, many scientific studies seek the maximization of surface oxygen vacancies on ceria catalysts by optimizing their design, as oxygen vacancies are generally known to be the active sites in multiple catalytic reactions. These investigations include exhaustive studies focused on the alteration of ceria redox properties with particle size, morphology and metal doping, as well as studies of surface oxygen mobility, oxygen storage capacity and the strong metal-support interaction (SMSI) effect. With this aim, ceria-based samples have been mainly studied under reducing $\left(\mathrm{H}_{2}\right)$ and oxidising $\left(\mathrm{O}_{2}\right)$ atmospheres and high temperatures, although the $\mathrm{CO}$ oxidation reaction has often been used as a probe reaction to evaluate redox properties as well.

The SMSI effect strongly alters the physicochemical properties of metal particles dispersed over reducible oxides after exposure to high-temperature reduction treatments. It has been found that the SMSI effect completely inhibits $\mathrm{H}_{2}$ and $\mathrm{CO}$ chemisorption capacity and, consequently, modifies adsorption and catalytic properties of metal/oxide systems [77]. Due to the unique redox behaviour of ceria, the SMSI effect occurs on ceria-supported metal catalysts when they are subjected to a reduction treatment, as several reports already demonstrated [78,79]. However, since the OSC of $\mathrm{CeO}_{2-x}(0<x<0.5)$ strongly depends on the temperature and oxygen pressure [80], the use of operando measurements is decisive to completely understand this effect. Several groups studied such phenomenon with the NAP-XPS technique. This is the case of Caballero et al., who demonstrated the appearance of the SMSI effect after exposing a Ni/CeO system to a reduction treatment at 1.3 mbar of $\mathrm{H}_{2}$ pressure at $773 \mathrm{~K}$ [81]. The catalyst of the study consisted on nickel nanoparticles deposited on a cerium oxide thin film using the Langmuir-Blodgett (LB) method. The huge decrease of the Ni 3p XPS signal during the reduction treatment (which was accompanied by $\mathrm{CeO}_{2-x}$ reduction) constituted a proof of the geometrical factor of the SMSI effect, which can be described as the migration of the support covering the metallic nanoparticles and thus blocking catalytic active sites. Nevertheless, this migration was reversible by removing the $\mathrm{H}_{2}$ gas phase at the same temperature, suggesting that the ceria phase preferentially migrated onto the Ni nanoparticles so as to absorb $\mathrm{H}_{2}$ through the formation of hydride-like species. Similar results were obtained by 
Bernardi et al., who exposed $\mathrm{Rh}_{0.5} \mathrm{Pd}_{0.5} / \mathrm{CeO}_{2}$ to consecutive processes of reduction and oxidation at different temperatures [82]. They observed not only the geometrical factor of the SMSI effect at $753 \mathrm{~K}$ during the reduction treatment at $0.13 \mathrm{mbar}_{2}$ pressure, that is, the coverage of bimetallic nanoparticles with a thin $\mathrm{CeO}_{2-x}$ capping layer, but they also identified it as the cause of a change of the atomic $\mathrm{Rh} / \mathrm{Pd}$ surface segregation behaviour, which led to nanoparticles with a Pd-rich surface configuration. Therefore, besides the described influence of the SMSI effect on the catalytic properties, the SMSI effect on ceria-based systems may also affect the atomic arrangement of bimetallic nanoparticles [68]. Another attempt to elucidate the nature of the SMSI effect was recently made by Figueiredo and co-workers through the study of $\mathrm{Cu}_{x} \mathrm{Ni}_{1-\mathrm{x}} / \mathrm{CeO}_{2}$ catalysts with different $\mathrm{Cu} / \mathrm{Ni}$ concentrations [83]. The samples were exposed to a reduction treatment at $773 \mathrm{~K}$ in a $\mathrm{H}_{2}$ atmosphere followed by an oxidation treatment with $\mathrm{CO}_{2}$ at the same temperature. The SMSI effect was only observed on those catalysts with high concentration of $\mathrm{Cu}$, and it was reversed upon oxidation with $\mathrm{CO}_{2}$. As a consequence of the SMSI effect, the reduction of $\mathrm{Cu}$ atoms of these nanoparticles occurs at lower temperatures than similar nanoparticles that do not display such effect. Finally, Carrasco et al. also reported the significance of the SMSI effect with the investigation of water adsorption on bare $\mathrm{CeO}_{2}(111)$ and on a $\mathrm{Ni} / \mathrm{CeO}_{2}(111)$ surface with a small coverage of $\mathrm{Ni}\left(\Theta_{\mathrm{Ni}} \sim 0.15 \mathrm{ML}\right.$, monolayer) [84]. Water dissociation is a critical step in many catalytic reactions over oxide-supported transition-metal catalysts. By combining ambient pressure XPS and density-functional theory (DFT) studies, researchers found a substantially larger amount of -OH groups adsorbed on the Ni-loaded-ceria surface than on the bare support. Water adsorption was not observed under ultra-high vacuum (UHV) conditions $\left(p_{\mathrm{H}_{2} \mathrm{O}}<10^{-7} \mathrm{mbar}\right)$, but adsorption occurred under water pressures above $10^{-3}$ mbar $(0.13$ and $0.26 \mathrm{mbar})$ at $300 \mathrm{~K}$, and part of the chemisorbed water molecules dissociated to generate hydroxyl groups on the surface. Adsorbed water and consequently $-\mathrm{OH}$ groups disappeared upon heating the systems at 500 and $700 \mathrm{~K}$ under $0.26 \mathrm{mbar}$ background pressure. Therefore, the type and amount of species adsorbed on both systems were strongly affected by the water pressure and the temperature of the surfaces. The rapid water dissociation on $\mathrm{Ni} / \mathrm{CeO}_{2}$ catalyst has a severe effect on the activity and stability of this system for the water-gas shift and steam reforming of ethanol reactions, since $-\mathrm{OH}$ groups can easily react with $\mathrm{CO}$ and $\mathrm{CH}_{\mathrm{x}}$ groups to produce $\mathrm{CO}_{2}$ and $\mathrm{H}_{2}$.

It is commonly accepted that the incorporation of a metallic active phase on a cerium oxide support alters its redox properties and, consequently, its catalytic activity. Therefore, ceria is usually combined with noble metals, such as $\mathrm{Ru}[85], \mathrm{Pt}[30,86,87]$, Pd [86-88], Rh [86,87] and Au [89-94] or with first-row non-noble transition metals, such as Fe [88], Co [88,95], $\mathrm{Cu}[96,97]$ or Ni [88,98], among others. A great deal of investigations about these systems is at present available due to its importance as a component of three-way catalysts (TWCs) exhaust gas purification systems, but only a few of them have been investigated by means of NAP-XPS. In 2013, Alayoglu et al. demonstrated the reversible reduction of mesoporous $\mathrm{CeO}_{2}$ under $\mathrm{H}_{2}$ atmospheres mediated by platinum nanoparticles using NAP-XPS [99]. The measurements, performed under 0.13 mbar of $\mathrm{H}_{2}$, revealed that cerium oxide was reduced at lower temperatures for $\mathrm{Pt} / \mathrm{CeO}_{2}$ catalyst than for pure mesoporous $\mathrm{CeO}_{2}$. This phenomenon was attributed to the spillover of atomic hydrogen from $\mathrm{Pt}$ to ceria surface: platinum nanoparticles dissociate $\mathrm{H}_{2}$ to $\mathrm{H}$, which spills onto $\mathrm{CeO}_{2}$ at the gas-solid interface and reduces the oxide through the formation of $\mathrm{OH}^{-}$or oxygen vacancies. Particularly, in hydrogen environments, $\mathrm{Pt}$ decreases the activation barrier for ceria reduction. These results were verified by near-edge $\mathrm{X}$-ray absorption fine structure (NEXAFS) and combined with X-ray diffraction (XRD) and extended X-ray absorption fine structure (EXAFS) measurements, which showed a reversible expansion and contraction of the $\mathrm{CeO}_{2}$ unit cell under $\mathrm{H}_{2}$ and $\mathrm{O}_{2}$ atmospheres, respectively, in accordance to the size of $\mathrm{Ce}^{3+}$ and $\mathrm{Ce}^{4+}$. Similar results were presented by Kato and co-workers [100], who also studied the reduction behaviour of nanostructured ceria-supported Pt catalyst, specifically platinum nanoparticles deposited on ceria nanocubes. They obtained a depth profile of the cerium oxidation state in the $\mathrm{CeO}_{2}$ nanocubes as a function of the gas environment and the loaded metal. To achieve so, NAP-XPS analyses were performed in a synchrotron by varying the energy of the X-rays and, thus, the probing depth. Under an atmosphere of $1 \mathrm{mbar}_{2}$ at $403 \mathrm{~K}$, oxygen vacancies were created only in the uppermost layers of 
the ceria nanocubes impregnated with Pt. The study of Sohn et al. was also focused on the surface oxygen mobility and oxygen vacancy formation of ceria nanoparticles, in this case depending on the particle dimensions as well as on the presence of an active metallic phase [101]. Nevertheless, ethanol steam reforming reaction conditions were used for their study instead of $\mathrm{H}_{2}$. Briefly, oxidation states of small ceria nanoparticles (NPs, $\sim 4 \mathrm{~nm}$ ) and larger particles (MPs, $\sim 120 \mathrm{~nm}$ ) were compared to those of cobalt-loaded NPs and MPs during a reductive pre-treatment at $673 \mathrm{~K}$ under $0.26 \mathrm{mbar} \mathrm{H}_{2}$ and the successive ethanol steam reforming under 0.13 mbar of ethanol and 1.3 mbar of water at 623,673 and $723 \mathrm{~K}$. Although both bare ceria NPs and MPs supports were active for the ethanol steam reforming, $\mathrm{Co} / \mathrm{CeO}_{2}-\mathrm{NP}$ was found to be the most active one and the one with the highest extent of reduced $\mathrm{CeO}_{2}$.

A well-known method to notably enhance cerium oxide redox activity is the addition of $3 \mathrm{~d}$ transition metals to its unit cell to form solid solutions with an ordered atomic arrangement $[3,102]$. For instance, it has been demonstrated that $\mathrm{Ce}_{1-x} \mathrm{M}_{\mathrm{x}} \mathrm{O}_{2-\mathrm{y}}$ mixed oxides (where $\mathrm{M}=\mathrm{Cr}[103,104]$, Mn [104-106], Fe [104,106], Co [104-106], Ni [105,106], Cu [107,108], Zr [109-111], La [112-114]) exhibit lower reduction temperatures than pure ceria. The incorporation of noble metals to ceria to generate $\mathrm{Ce}_{1-x} \mathrm{M}^{\prime}{ }_{\mathrm{x}} \mathrm{O}_{2-y}$ mixed oxides ( $\left.\mathrm{M}^{\prime}=\mathrm{Ru}[115], \mathrm{Rh}[116,117], \mathrm{Pd}[117,118]\right)$ has also demonstrated to efficiently promote reducibility of cerium ions and greatly decrease the reduction temperatures too [119]. Ikemoto et al. investigated the reversible redox activity of $\mathrm{Cr}_{0.19} \mathrm{Rh}_{0.06} \mathrm{CeO}_{\mathrm{x}}$ by means of NAP-XPS, while its catalytic properties were tested with $\mathrm{CO}$ and 1-octanol oxidation reactions [120]. NAP-XPS

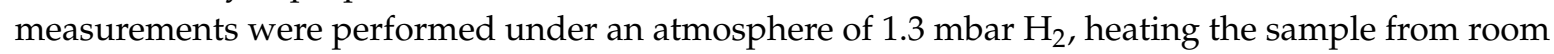
temperature to $385 \mathrm{~K}$ and then cooling it again. Reduction was followed by an oxidation treatment at $573 \mathrm{~K}$ under $2 \mathrm{mbar} \mathrm{O}_{2}$. Combined with in situ XAFS analysis, the results revealed the transformation of dispersed $\mathrm{Rh}^{\delta+}$ species and small $\mathrm{CrO}_{\mathrm{x}}$ nanoparticles supported on $\mathrm{CeO}_{2}$ to $\mathrm{Rh}$ nanoclusters, $\mathrm{Cr}(\mathrm{OH})_{3}$ species and $\mathrm{CeO}_{2-x}$ when treated with $\mathrm{H}_{2}$. Thus, they demonstrated a remarkable and reversible low-temperature redox activity of $\mathrm{Cr}_{0.19} \mathrm{Rh}_{0.06} \mathrm{CeO}_{x}$ due to the combined contribution of the three metal species, which do not reduce below $373 \mathrm{~K}$ when they exist separately.

Della Mea et al. studied the redox properties of differently prepared ceria nanoparticles exposed to $1 \mathrm{mbar} C \mathrm{CO}$ reducing atmosphere and high temperature [121]. Their aim was to tune the oxygen vacancy population in order to design a rational and optimal ceria catalyst for $\mathrm{CO}$ oxidation. More than ten different $\mathrm{CeO}_{2}$ nanoparticle types were prepared by modifying synthesis parameters and two of them were studied with NAP-XPS, as well as standard $\mathrm{CeO}_{2}$. They found that small size, high initial $\mathrm{Ce}^{3+}$ content, high surface area and low pore volume decreased the ceria reduction temperature. Similar investigations were performed by Pereira-Hernández and co-workers [122], who compared the low-temperature $(<423 \mathrm{~K}) \mathrm{CO}$ oxidation performance of $\mathrm{Pt} / \mathrm{CeO}_{2}$-based catalysts prepared via conventional wet chemical synthesis (strong electrostatic adsorption) or high-temperature gas phase synthesis (atom trapping). The samples prepared by atom trapping caused Pt to covalently bond with the surface oxygen atoms as well as ceria restructuration. As synthesised, both catalysts were inactive for low-temperature $\mathrm{CO}$ oxidation, but their reactivity improved after a treatment under 2 mbar $\mathrm{CO}$ at $548 \mathrm{~K}$. The combination of NAP-XPS and CO temperature-programmed reduction (CO-TPR) showed that the catalyst prepared by atom trapping achieved higher activity for $\mathrm{CO}$ oxidation after reduction in $\mathrm{CO}$ at $548 \mathrm{~K}$, step that led to the partial transformation of Pt single atoms into Pt clusters.

Sayle et al. claimed on the basis of non-equilibrium Molecular Dynamics simulations that the catalytic activity of cerium oxide in the catalytic $\mathrm{CO}$ oxidation reaction could be predicted by knowing the oxygen vacancy population at its surface [123]. A catalytic activity map for ceria was presented in their report, calculated as a function of size, shape, architecture and defect content. Their simulations were supported by NAP-XPS analyses of two samples of ceria nanoparticles with different initial surface $\mathrm{Ce}^{3+} / \mathrm{Ce}^{4+}$ ratios.

Another approach for the study of ceria catalytic properties by NAP-XPS was reported by Gopal et al., who quantified the effect that large biaxial strain generated on ultrathin ceria films had on the surface redox behaviour of $\mathrm{CeO}_{2-x}$ [124]. They prepared ultrathin cerium oxide films under biaxial compression on single-crystalline (001) yttria-stabilized zirconia (YSZ) and under biaxial tension on 
(001) $\mathrm{SrTiO}_{3}(\mathrm{STO})$, taking advantage of the high lattice mismatch between ceria and both substrates, which modifies the interatomic distances of ceria lattice and causes significant changes in its electronic structure and redox capacity. Samples were studied by different characterization techniques, but surface $\mathrm{Ce}^{3+}$ and oxygen vacancy concentrations were directly quantified by means of NAP-XPS at 723 and $823 \mathrm{~K}$ in both $\mathrm{O}_{2}$ and $\mathrm{H}_{2} / \mathrm{H}_{2} \mathrm{O}$ atmospheres and compared with those of fully relaxed ceria films. The results revealed a significant enhancement of $\mathrm{Ce}^{3+}$ and oxygen vacancy concentrations near the surface for both compressive and tensile strained oxide films.

\subsection{Gas-Solid Catalysis}

Since NAP-XPS was first developed, investigations of gas-solid interfaces have been the frontrunner of the technique due to the many relevant applications they have in the fields of catalysis, corrosion, energy materials and atmospheric science [62,125]. Additionally, the preparation and measurement of gas-solid interfaces with NAP-XPS are relatively simple compared to, e.g., measurements of liquid interfaces. In particular, there has been recently great interest and success in the study of real and model catalytic systems, as well as electrochemical devices, with one or multiple reactant gases. These studies included adsorption, reaction induced restructuring and catalytic performance of systems ranging from highly-ordered single crystals to supported nanoparticles. Therefore, in this second block we have collected and organised all the reports of gas-solid catalytic reactions with ceria-based systems found in the literature, which emphasize the advantages and deficiencies of the NAP-XPS technique in these gas-solid interfaces. Table 1 provides a list of reports of NAP-XPS studies of ceria-based catalysts in the presence of gases published so far, which are described in the following paragraphs.

Table 1. Published near ambient pressure X-ray photoelectron spectroscopy (NAP-XPS) investigations of ceria-based catalysts in gas-solid reactions.

\begin{tabular}{|c|c|c|c|c|c|c|}
\hline Reaction & Catalyst & $P_{\max }$ (mbar) & $\mathrm{T}(\mathrm{K})$ & X-ray Source & Year & Ref. \\
\hline \multirow{9}{*}{$\begin{array}{l}\mathrm{CO} \text { oxidation and preferential CO } \\
\text { oxidation (PROX) }\end{array}$} & $5 \% \mathrm{Pt} / \mathrm{CeO}_{2}$ & $\sim 0.5$ & $358-523$ & Synchrotron & 2006 & [126] \\
\hline & $5 \% \mathrm{Pd} / \mathrm{CeO}_{2}$ & $\sim 0.5$ & $358-523$ & Synchrotron & 2006 & [127] \\
\hline & $5 \% \mathrm{Pt} / \mathrm{CeO}_{2}$ & $\sim 1$ & 393 & Synchrotron & 2007 & [128] \\
\hline & $\mathrm{Au}-\mathrm{Ni} / \mathrm{CeO}_{2}$ & $\sim 1$ & 523 & Synchrotron & 2013 & [129] \\
\hline & $\begin{array}{l}1 \% \mathrm{Cu} / \mathrm{CeO}_{2} \text { nanospheres } \\
1 \% \mathrm{Cu} / \mathrm{CeO}_{2} \text { nanocubes }\end{array}$ & $\sim 1$ & $300-553$ & Synchrotron & 2015 & [130] \\
\hline & $10 \% \mathrm{CeO}_{2} / \mathrm{Co}_{3} \mathrm{O}_{4}$ & 0.5 & $300-573$ & Synchrotron & 2016 & [131] \\
\hline & $3 \% \mathrm{Pt} / \mathrm{CeO}_{2}$ & 1 & 373 & Synchrotron & 2017 & [132] \\
\hline & $\mathrm{CeO}_{2}$ nanoparticles & $\sim 1$ & $373-773$ & Lab-based & 2017 & [121] \\
\hline & $1 \% \mathrm{Pt} / \mathrm{CeO}_{2}$ & $\sim 2$ & $323-373$ & Lab-based & 2019 & [122] \\
\hline \multirow{4}{*}{ Water-gas shift reaction (WGS) } & $2.5 \%$ & & & & & \\
\hline & $\begin{array}{l}\mathrm{M} @ m e s o p o r o u s-\mathrm{CeO}_{2} 2.5 \% \\
\mathrm{M} / \mathrm{rod}-\mathrm{CeO}_{2} \\
(\mathrm{M}=\mathrm{Au}, \mathrm{Pt}, \mathrm{Pd}, \mathrm{Cu})\end{array}$ & 1.95 & $403-543$ & Lab-based & 2012 & [133] \\
\hline & $\mathrm{CeO}_{2} / \mathrm{CuO}$ & 0.5 & $473-523$ & Synchrotron & 2012 & [134] \\
\hline & $\begin{array}{l}\mathrm{CeO}_{x} / \mathrm{Cu}(111) \\
\mathrm{CeO}_{x} / \mathrm{Au}(111)\end{array}$ & $\sim 0.5$ & $300-573$ & Synchrotron & 2013 & [39] \\
\hline Soot oxidation & $\begin{array}{l}\mathrm{CeO}_{2} \text { and } \mathrm{Ce}_{0.8} \mathrm{Zr}_{0.2} \mathrm{O}_{2} \\
\text { nanoparticles }\end{array}$ & 1 & $300-823$ & Synchrotron & 2016 & [135] \\
\hline \multirow{4}{*}{$\mathrm{CO}_{2}$ hydrogenation } & $\mathrm{CeO}_{x} / \mathrm{Cu}(111)$ & 0.39 & 473 & Synchrotron & 2014 & [136] \\
\hline & $\mathrm{CeO}_{x} / \mathrm{Cu}(111)$ & $\sim 0.4$ & $300-500$ & Synchrotron & 2016 & [137] \\
\hline & $\begin{array}{l}5 \% \mathrm{Cu} / \mathrm{CeO}_{2} \text { nanospheres } \\
5 \% \mathrm{Cu} / \mathrm{CeO}_{2} \text { nanorods }\end{array}$ & 0.06 & $300-723$ & Lab-based & 2018 & [97] \\
\hline & $0.5,1.5$ and $5 \% \mathrm{Ni} / \mathrm{CeO}_{2}$ & $\sim 0.06$ & $300-623$ & Lab-based & 2019 & [138] \\
\hline
\end{tabular}


Table 1. Cont.

\begin{tabular}{|c|c|c|c|c|c|c|c|}
\hline Reaction & & Catalyst & $P_{\max }(\mathrm{mbar})$ & $\mathrm{T}(\mathrm{K})$ & X-ray Source & Year & Ref. \\
\hline \multirow{11}{*}{ Hydrocarbons } & \multirow{3}{*}{$\begin{array}{l}\text { Oxidation and } \\
\text { partial } \\
\text { oxidation }\end{array}$} & $\begin{array}{l}5 \% \mathrm{M} / \mathrm{CeO}_{2} \\
(\mathrm{M}=\mathrm{Pd}, \mathrm{Pt}, \mathrm{Rh})\end{array}$ & 3.9 & $300-873$ & Lab-based & 2013 & [139] \\
\hline & & $\mathrm{Co}_{3} \mathrm{O}_{4} / \mathrm{CeO}_{2}$ nanorods & 1.56 & $423-773$ & Lab-based & 2018 & [140] \\
\hline & & $15 \% \mathrm{NiO} / \mathrm{CeO}_{2}$ nanorods & 1.56 & $423-773$ & Lab-based & 2018 & [141] \\
\hline & \multirow{8}{*}{ Dry reforming } & $26 \% \mathrm{Ni} / \mathrm{CeO}_{2}$ & 1.3 & $773-923$ & Synchrotron & 2008 & [142] \\
\hline & & $\mathrm{Ni} / \mathrm{CeO}_{2}(111)$ & 0.26 & $300-700$ & Synchrotron & 2016 & [143] \\
\hline & & $\mathrm{Ni} / \mathrm{CeO}_{2}(111)$ & 0.26 & 700 & Synchrotron & 2016 & [144] \\
\hline & & $\begin{array}{l}1.5 \% \mathrm{Ni}, 1.7 \% \mathrm{Pt} \text { and } \\
\mathrm{PtNi} / \mathrm{CeO}_{2} / \mathrm{TiO}_{2}(110)\end{array}$ & 0.39 & $303-723$ & Synchrotron & 2016 & [145] \\
\hline & & $\begin{array}{l}\mathrm{M} / \mathrm{CeO}_{2}(111) / \mathrm{Ru}(0001) \\
(\mathrm{M}=\mathrm{Co}, \mathrm{Ni}, \mathrm{Cu})\end{array}$ & 0.13 & $300-700$ & Lab-based & 2017 & [146] \\
\hline & & $10 \% \mathrm{Co} / \mathrm{CeO}_{2}$ & $\sim 0.2$ & $300-773$ & Lab-based & 2018 & [147] \\
\hline & & $\begin{array}{l}\mathrm{PtCo} / \mathrm{CeO}_{2}(\mathrm{Pt}=1.67 \%, \\
\mathrm{Co}=1.51 \%)\end{array}$ & 0.052 & 823 & Lab-based & 2018 & [148] \\
\hline & & $0.5 \% \mathrm{Ru}(\mathrm{NC}) / \mathrm{CeO}_{2}$ & 0.13 & $300-773$ & Lab-based & 2019 & [149] \\
\hline \multirow{10}{*}{ Alcohols } & \multirow{9}{*}{$\begin{array}{l}\text { Steam } \\
\text { reforming (SR) }\end{array}$} & $\begin{array}{l}\mathrm{CeO}_{2}(111) / \mathrm{Cu}(111) \\
\mathrm{Co} / \mathrm{CeO}_{2}(111) / \mathrm{Cu}(111)\end{array}$ & 1 & $320-600$ & Lab-based & 2013 & [150] \\
\hline & & $3 \% \mathrm{Rh}_{0.5} \mathrm{Pd}_{0.5} / \mathrm{CeO}_{2}$ & 0.05 & 823 & Synchrotron & 2014 & [68] \\
\hline & & $8 \% \mathrm{Co} / \mathrm{CeO}_{2}$ & 0.2 & $523-693$ & Synchrotron & 2016 & [151] \\
\hline & & $23 \% \mathrm{Co} / \mathrm{CeO}_{2}$ & 0.3 & 693 & Synchrotron & 2016 & [152] \\
\hline & & $\begin{array}{l}10 \% \mathrm{Co} / \mathrm{CeO}_{2}-\mathrm{NP}^{\mathrm{a}} \\
10 \% \mathrm{Co} / \mathrm{CeO}_{2}-\mathrm{MP}^{\mathrm{b}}\end{array}$ & 1.43 & $623-723$ & Lab-based & 2016 & [153] \\
\hline & & $\mathrm{Ni} / \mathrm{CeO}_{2}(111) / \mathrm{Ru}(0001)$ & $\sim 0.3$ & $300-700$ & Synchrotron & 2016 & [154] \\
\hline & & $\begin{array}{l}\mathrm{Co} / \mathrm{CeO}_{2}-\mathrm{NP} \\
\mathrm{Co} / \mathrm{CeO}_{2}-\mathrm{MP}\end{array}$ & 1.43 & $623-723$ & Lab-based & 2017 & [101] \\
\hline & & $\begin{array}{l}\mathrm{Ni} / \mathrm{CeO}_{2} \\
\mathrm{Ni} / \mathrm{CeO}_{2-\mathrm{x}} / \mathrm{Ru}(0001)\end{array}$ & $2 L^{*}$ & $300-700$ & Synchrotron & 2018 & [155] \\
\hline & & $\begin{array}{l}3 \% \mathrm{Rh}_{0.5} \mathrm{Pd}_{0.5} / \mathrm{CeO}_{2} \\
\text { nanocubes } \\
3 \% \mathrm{Rh}_{0.5} \mathrm{Pd}_{0.5} / \mathrm{CeO}_{2} \\
\text { nanorods }\end{array}$ & 0.05 & 823 & Synchrotron & 2019 & [69] \\
\hline & Oxidation & $\mathrm{CeO}_{2}(100) / \mathrm{STO}(100)$ & 0.39 & $523-723$ & Synchrotron & 2018 & [156] \\
\hline \multirow{2}{*}{\multicolumn{2}{|c|}{ Hydrogenation reactions }} & $\mathrm{CeO}_{2}$ nanorods & 0.65 & $533-673$ & Lab-based & 2017 & [157] \\
\hline & & $\mathrm{CeO}_{2} / \mathrm{Pt}$ & 0.39 & $300-473$ & Lab-based & 2017 & [158] \\
\hline
\end{tabular}

${ }^{a} \mathrm{NP}=$ nanoparticles; ${ }^{\mathrm{b}} \mathrm{MP}=$ microparticles; ${ }^{*} \mathrm{~L}=$ Langmuir.

\subsubsection{CO Oxidation and Preferential CO Oxidation (PROX)}

The preferential oxidation of carbon monoxide (PROX) is considered an essential reaction to produce high-pure hydrogen for proton-exchange membrane fuel cells (PEMFCs), which must be CO-free for their proper operation [159]. In fact, the concentration of CO in the hydrogen feed must be kept as low as possible (below 1-100 ppm as a rule) [160]. This can be achieved by using sequential water-gas shift (WGS) and PROX units; the former one reduces the amount of CO to $0.5 \%-1 \%$ [159] and then PROX reaction reduces this concentration to $<100 \mathrm{ppm}$ by selectively oxidising $\mathrm{CO}$, avoiding the oxidation of hydrogen. An appropriate catalyst for PROX reaction should not only adsorb carbon monoxide but also supply activated oxygen, as long as hydrogen adsorption is suppressed. Many catalytic formulations have already been applied for PROX reaction, among them supported noble metals such as Au [161-164], Pt [162,164-167], Rh [165] and Ru [165,168], which are responsible for CO adsorption. However, oxygen does not adsorb on these metals because their surface is fully covered by $\mathrm{CO}$ molecules, so different activation sites are required for $\mathrm{O}_{2}$. Here is where cerium oxide becomes important as a component of these catalysts, because of its role as a reducible support for metallic nanoparticles, able to promote oxidation even under oxygen-poor conditions [76]. In order to gain further insight into the reaction mechanism of the PROX reaction on ceria-based catalysts, several research groups examined changes in the oxidation state of ceria and the supported metal, as well as the surface adsorbed species, under PROX conditions by means of the NAP-XPS technique. Pozdnyakova et al. examined the Pt/ceria [126] and Pd/ceria [127] catalytic systems in separate papers using the same techniques, so as to obtain a better understanding of the PROX reaction mechanism when comparing 
both systems, although it is well-known that palladium is far less active in this reaction. Both systems were performed with $5 \mathrm{wt} \%$ metal loading and studied under approximately 0.5 mbar PROX mixture $\left(\mathrm{CO}+\mathrm{O}_{2}+\mathrm{H}_{2}\right)$ after being first activated in an oxygen environment $(0.5 \mathrm{mbar}, 573 \mathrm{~K})$, but also were studied under a $\mathrm{CO}$ and $\mathrm{O}_{2}$ mixture, pumping the hydrogen pressure out of the analysis chamber. The combination of in situ diffuse reflectance infrared Fourier transform spectroscopy (DRIFTS), which aided the identification of surface species, and NAP-XPS allowed the clarification of the main question of the work: why both Pt and Pd catalysts are active in $\mathrm{CO}$ oxidation but $\mathrm{Pd}$ is not active and selective in the presence of $\mathrm{H}_{2}$ (PROX reaction). Researchers concluded that at PROX conditions and low temperatures ( $\mathrm{T}=350-380 \mathrm{~K}) \mathrm{CO}$ oxidation was suppressed due to the easy formation of Pd $\beta$-hydride, identified by NAP-XPS. Adsorbed $\mathrm{H}$ rapidly reacted with oxygen from both gas-phase and support sites (also from $\mathrm{PdO}_{\mathrm{x}}$ phase) and formed water, which desorbed easily. However, $\mathrm{CO}$ adsorption was not completely inhibited, and instead of being oxidised it partially became surface formate and formyl $(-\mathrm{CHO})$ species. The hydride phase decomposed at higher temperatures, which led to an increase of the selectivity toward CO oxidation. Nevertheless, it was still lower on $\mathrm{Pd} / \mathrm{CeO}_{2}$ than on $\mathrm{Pt} / \mathrm{CeO}_{2}$, likely due to the preference of metallic $\mathrm{Pd}$ for $\mathrm{H}$ adsorption rather than $\mathrm{CO}$, and also because $\mathrm{PdO}_{2}$ surface preferentially oxidises $\mathrm{H}$ with respect to $\mathrm{CO}$. Teschner and co-workers [128] also examined $\mathrm{Pt} / \mathrm{CeO}_{2}$ catalysts (with nominal platinum loading of $5 \mathrm{wt} \%$ ) with operando XPS but under different PROX mixtures, by varying oxygen pressure in the reactant feed of a first set of measurements and CO pressure in a second set, always maintaining the same $\mathrm{H}_{2}$ pressure value for both series so that the total chamber pressure was approximately 1 mbar. The prepared catalyst removed $99 \%$ of CO from a model feed, and the authors suggested the "classic" non-competitive mechanism of low-temperature CO oxidation on ceria-supported Pt [169] (e.g., CO adsorption on platinum and oxygen activation on the ceria support), and CO oxidation on the metal/oxide interface. Additionally, they found that oxygen vacancy formation, detected by operando XPS, was directly related to an enhancement of CO oxidation activity, because higher vacancy densities hindered water desorption, so that water molecules blocked $\mathrm{H}_{\mathrm{ads}}$ oxidation sites and, therefore, more oxygen atoms were freely available for the oxidation of carbon monoxide. Ceria-supported $\mathrm{Pt}$ [170], Rh [171] and Pd [172] are also notably active in the low-temperature $\mathrm{CO}$ oxidation, a catalytic reaction important to lower automotive emissions $[34,173]$. For instance, Artiglia et al. [132] characterised the surface of a $3 \mathrm{wt} \% \mathrm{Pt} / \mathrm{CeO}_{2}$ powder catalyst under 1 mbar of a reacting mixture of $\mathrm{CO}$ and $\mathrm{O}_{2}$, employing time-resolved techniques to study the short-lived $\mathrm{Ce}^{3+}$ species, difficult to detect under steady-state conditions [174]. This new approach, based on NAP-XPS, consisted on the acquisition of a Ce $3 \mathrm{~d}$ core level fast scan while switching the oxygen on and off (and replacing it with nitrogen) in a carbon monoxide/oxygen reaction mixture. The results obtained with the combination of these pulsed experiments and analyses of the depth profile, achieved by modifying the excitation energy, indicated that active $\mathrm{Ce}^{3+}$ sites were formed transiently at the most superficial layers of ceria and at the $\mathrm{Pt} / \mathrm{CeO}_{2}$ interface when oxygen was switched off [175]. Active sites were immediately reoxidised to $\mathrm{Ce}^{4+}$ upon dosing oxygen. Furthermore, when performing the same experiment on bare ceria they found insignificant reduction, which revealed the role of platinum as a promoter of the formation of $\mathrm{Ce}^{3+}$ at the interface. Recently, Pereira and co-workers have also investigated the performance of $\mathrm{Pt} / \mathrm{CeO}_{2}$-based catalysts for the low-temperature $(<423 \mathrm{~K})$ CO oxidation [122], as mentioned earlier. The use of copper for ceria based catalyst is an interesting and promising alternative to noble metals for processes involving also $\mathrm{CO}$ oxidation, such as the water-gas shift reaction or the PROX [176,177]. Precisely, the work presented by Monte et al. consisted of the comparison of two morphologically different ceria supports (nanospheres and nanocubes) impregnated with a copper metallic phase subjected to interaction with carbon monoxide at different temperatures [130]. Their results provided direct evidence of interfacial $\mathrm{Cu}^{+}$sites, which are suggested to be the most active ones for CO oxidation [177,178], observed during near-ambient XPS experiments performed over both catalysts subjected to thermal reduction under a flow of diluted CO. These experimental results were supported by density functional theoretical calculations, supplemented with a Coulombic interaction parameter $(\mathrm{DFT}+\mathrm{U})$, and they demonstrated lower reducibility of the $\mathrm{CuO}$ 
nanoparticles supported on ceria nanocubes, which led to a higher barrier to oxidise $\mathrm{H}_{2}$ and thus to an enhancement of the CO PROX selectivity, as observed in previous investigations for ceria support with (100) faces [179]. Another type of design that has been used for CO oxidation reaction, and it has also been studied with operando spectroscopic techniques such as NAP-XPS, consists of bimetallic ceria-based catalysts. The work of Holgado et al. is focused on $\mathrm{Au}-\mathrm{Ni} / \mathrm{CeO}_{2}$ bimetallic catalysts and their analogous monometallic samples [129]. In particular, they studied the effect of Ni incorporation into gold nanoparticles on their catalytic activity, as well as the distribution of $\mathrm{Ni}$ and $\mathrm{Au}$ atoms in bimetallic nanoparticles using various techniques. The development of gold bimetallic catalysts receives economic interest if the second metal is cheaper than $\mathrm{Au}$, such as copper or nickel. Their investigation demonstrated that $\mathrm{Au}-\mathrm{Ni} / \mathrm{CeO}_{2}$ bimetallic catalysts presented higher reactivity towards $\mathrm{CO}$ oxidation than monometallic $\mathrm{Au} / \mathrm{CeO}_{2}$ and $\mathrm{Ni} / \mathrm{CeO}_{2}$. The different operando characterization techniques used, including NAP-XPS, allowed them to establish a core-shell Au@NiO distribution, in which Ni surface atoms experienced an electronic effect on the local density of $\mathrm{Ni} d$ states from $\mathrm{Au}$ atoms in the core, modifying, in turn, their chemical and reactivity properties. It is worth mentioning that the bimetallic catalyst was studied by NAP-XPS under $1 \mathrm{mbar}_{2}$ reducing atmosphere instead of $\mathrm{CO}$ (also a reducing agent) due to the possible formation of volatile Ni carbonyl species that could contaminate the analysis chamber. As already mentioned above, Della Mea and co-workers [121] also studied differently prepared ceria catalysts, altering their oxygen vacancy population, in order to design a rational ceria catalyst for CO oxidation. In this case, NAP-XPS conditions were 1 mbar of CO gas phase and temperatures from 373 to $773 \mathrm{~K}$. Finally, another alternative to non-noble metals for PROX catalysts is the use of transition metal oxides, such as copper and cobalt-based catalysts, which show potential for this reaction [179-184]. Cobalt oxide catalysts have been extensively studied and, in order to improve their catalytic performance, reducible metal oxides (e.g., $\mathrm{MnO}_{2}, \mathrm{CeO}_{2}$ ) have been incorporated $[183,184]$. Although $\mathrm{Co}_{3} \mathrm{O}_{4}$ is a promising candidate as a CO-PROX catalyst, detailed knowledge of its active sites under reaction conditions is still missing. Therefore, in order to improve the understanding of PROX over cobalt oxide-based catalysts, Lukashuk et al. studied them employing advanced operando methods such as NAP-XPS at low photon energies, which allowed higher surface sensitivity to monitor changes in the surface composition [131]. In this case, the cerium oxide role was not as a support for Co nanoparticles but was instead loaded $(10 \mathrm{wt} \%)$ on as received $\mathrm{Co}_{3} \mathrm{O}_{4}$ nanoparticles via wet impregnation. Both bare $\mathrm{Co}_{3} \mathrm{O}_{4}$ and $\mathrm{CeO}_{2} / \mathrm{Co}_{3} \mathrm{O}_{4}$ catalysts were studied under pure $\mathrm{CO}(0.15 \mathrm{mbar})$, pure $\mathrm{H}_{2}$ (0.4 mbar) or under $\mathrm{PROX}$ mixture $\left(\mathrm{CO} / \mathrm{O}_{2} / \mathrm{H}_{2}\right.$ ratio of $1 / 1 / 12$, at $\left.0.5 \mathrm{mbar}\right)$, and the ability of $\mathrm{Co}_{3} \mathrm{O}_{4}$ to reduce in pure $\mathrm{CO}$ and easily reoxidise in $\mathrm{O}_{2}$ suggested that adsorbed $\mathrm{CO}$ molecules react with lattice oxygen, which is refilled upon dosing $\mathrm{O}_{2}$. Moreover, the addition of $\mathrm{CeO}_{2}$ to $\mathrm{Co}_{3} \mathrm{O}_{4}$ promoted the PROX activity and increased the reduction temperatures under $\mathrm{CO}$ and $\mathrm{H}_{2}$, although being a less active material.

\subsubsection{Water-Gas Shift Reaction (WGS)}

The water-gas shift (WGS) reaction (see Equation (1)) is widely used in industry to tune the $\mathrm{CO} / \mathrm{H}_{2}$ ratio in several chemical processes and to increase the yield of hydrogen in reforming processes. Again, ceria-based catalysts are promising candidates for such application [86,185], and their combination with noble metals $(\mathrm{Au}, \mathrm{Pt}, \mathrm{Pd}, \mathrm{Ni}, \mathrm{Co})$ have received widespread attention due to the enhancement of their activity $[76,86,169,186]$.

$$
\mathrm{CO}+\mathrm{H}_{2} \mathrm{O} \rightarrow \mathrm{CO}_{2}+\mathrm{H}_{2} ; \Delta \mathrm{H}=-41.2 \mathrm{~kJ} / \mathrm{mol},
$$

Wen and colleagues [133] used NAP-XPS to track the surface chemistry of two types of prepared ceria-based catalysts under WGS reaction conditions. They synthesised metal nanoclusters ( $\mathrm{Au}, \mathrm{Pt}$, $\mathrm{Pd}, \mathrm{Cu}$ ) and supported them in channels of mesoporous ceria (abbreviated $\mathrm{M} @ m p-\mathrm{CeO}_{2}$ ), as well as on ceria nanorods, and compared their performance for the WGS reaction. NAP-XPS measurements allowed the identification of the metallic state for $\mathrm{Au}, \mathrm{Pt}, \mathrm{Pd}$ and $\mathrm{Cu}$ nanoclusters, and revealed a higher concentration of oxygen vacancies under WGS reaction conditions on the internal concave surface of 
$m p-\mathrm{CeO}_{2}$ pores than on ceria nanorods surface. They associated the lower density of oxygen vacancies in ceria nanorods with stronger adsorption of $\mathrm{OH}^{-}$groups because the limited space of the concave internal surface of $m p-\mathrm{CeO}_{2}$ increases repulsion between neighbouring hydroxyl groups. These results correlated well with the low calculated activation energy of WGS reaction on $\mathrm{M} @ m p-\mathrm{CeO}_{2}$ catalysts in contrast to those of $\mathrm{M} / \mathrm{CeO}_{2}$ nanorods.

Ceria-based catalysts, most of them composed by ceria nanoparticles loaded with a metallic phase by incipient wet impregnation, have been widely used so far. Some cerium oxide films have also been assessed and quoted, yet few inverse configurations of catalysts (i.e., those in which ceria is supported on a metallic phase, exchanging its role as catalyst support) have been studied albeit in some cases they could apparently display enhanced activity compared to the conventional direct configuration $[187,188]$. From an economical point of view, catalysts formulations that combine copper and cerium oxide become more interesting than those based on noble metals. Copper-ceria catalysts have been proposed to operate at a relatively high temperatures above $573 \mathrm{~K}$ for WGS reaction, where $\mathrm{CO}$ and $\mathrm{H}_{2} \mathrm{O}$ act as a reducing and oxidising agent of ceria, respectively, in the presence of active metallic $\mathrm{Cu}$ [188]. In this context, López Cámara et al. prepared an inverse $\mathrm{CeO}_{2} / \mathrm{CuO}$ catalyst by a microemulsion-based method and examined it separately by operando XPS and DRIFTS spectroscopies under reactant mixtures relevant to the low temperature WGS reaction [134]. Their experiments demonstrated that water adsorption promoted the reduction of the catalyst to achieve its most active state since $\mathrm{H}_{2} \mathrm{O}$ molecules favoured the decomposition of surface carbonate species which hamper the reduction process. Another attempt to shed light on the role of metal-oxide interfaces for the WGS reaction mechanism is the work of Mudiyanselage et al., who combined NAP-XPS, infrared reflection absorption spectroscopy (IRRAS) and DFT calculations to investigate the WGS reaction on $\mathrm{CeO}_{x}$ nanoparticles deposited on $\mathrm{Cu}(111)$ and $\mathrm{Au}(111)$ substrates [39]. $\mathrm{Cu}(111)$ constitutes a typical benchmark for water-gas shift reaction studies, whereas $\mathrm{Au}(111)$ is inactive for such reaction. Nevertheless, it can be activated in the presence of ceria nanoparticles $[187,189]$. Under mild WGS conditions, adsorbed $\mathrm{CO}_{2}{ }^{{ }^{-}-}$species were detected over both $\mathrm{CeO}_{x} / \mathrm{Cu}(111)$ and $\mathrm{CeO}_{x} / \mathrm{Au}(111)$ systems, as well as a high degree of reduction of ceria. Both NAP-XPS and DFT analyses showed that $\mathrm{CO}_{2}{ }^{{ }^{-}-}$species, originated from a carboxy (HOCO) intermediate, are stabilized at the metal-oxide interface of the catalysts, and the simultaneous contribution of atoms present on the metal and the oxide allow the formation of such species, favouring a hydrogen production reaction mechanism which is not efficient on bare copper or bare ceria.

\subsubsection{Soot Oxidation}

Soot particles consist of an amorphous carbon core of few nanometers surrounded by a graphitic shell, often carrying many toxic compounds [190-192], and are one of the main pollutants emitted by diesel engines. Since thermal combustion of soot requires temperatures above $873 \mathrm{~K}$ with oxygen, and the temperature of diesel exhaust gases typically lies between 473 and $673 \mathrm{~K}$, a suitable catalyst is needed to decrease the ignition temperature $[193,194]$. Among all the reported catalysts, ceria-based ones appear to be exceptional candidates for soot oxidation [195-197]. Concerning this reaction, it is generally assumed that it conforms to the Mars-van Krevelen mechanism, in which lattice oxygen atoms of the outmost layers of ceria are transferred onto soot, and exposure to gaseous $\mathrm{O}_{2}$ subsequently fills up the vacancies created on the oxide $[198,199]$. Therefore, it is claimed that the formation of paramagnetic $\mathrm{O}_{2}{ }^{-}$superoxide and diamagnetic $\mathrm{O}_{2}{ }^{2-}$ peroxide species takes place when reduced $\mathrm{CeO}_{2-x}$ is exposed to molecular $\mathrm{O}_{2}[26,200,201]$, which spillover onto soot surface [202], and that these active species are actually the main cause of soot oxidation [203,204]. By means of ambient pressure XPS, Soler et al. provided direct evidence of the redox chemistry and the influence of the reaction conditions in the oxidation of carbon soot over ceria-based catalysts [135]. With this aim, they investigated a sample of conventional ceria and a sample of $\mathrm{Ce}_{0.8} \mathrm{Zr}_{0.2} \mathrm{O}_{2}$ mixed with soot, which were subjected to increasing temperatures (from 300 to $823 \mathrm{~K}$ ) under 1 mbar argon atmosphere in a first set of experiments (with a final replacement of Ar with $\mathrm{O}_{2}$ at $823 \mathrm{~K}$ ), and under 1 mbar oxygen atmosphere in a second set of measurements. It is well-known that heating ceria under an inert atmosphere such as Ar results in the formation of oxygen vacancies and 
the concurrent reduction of $\mathrm{Ce}^{4+}$ to $\mathrm{Ce}^{3+}$ [205], and the results showed indeed a $\mathrm{Ce}^{3+}$ increase with the temperature. However, when samples were treated with $\mathrm{O}_{2}$, the amount of $\mathrm{Ce}^{3+}$ species remained low over the entire temperature range, since molecular oxygen rapidly reacted with the oxygen vacancies created at the ceria-soot interface. Interesting results were obtained when comparing the behaviour of $\mathrm{CeO}_{2}$-soot and $\mathrm{Ce}_{0.8} \mathrm{Zr}_{0.2} \mathrm{O}_{2}$-soot systems, since the amount of $\mathrm{Ce}^{3+}$ species upon heating under an $\mathrm{Ar}$ atmosphere was higher for the $\mathrm{Zr}$-doped sample in all cases. Figure 1 shows $\mathrm{Ce} 3 \mathrm{~d}(\mathrm{a}, \mathrm{b})$ and $\mathrm{O} 1 \mathrm{~s}$ spectra $(c, d)$ of the $\mathrm{Ce}_{0.8} \mathrm{Zr}_{0.2} \mathrm{O}_{2}$-soot sample recorded at $823 \mathrm{~K}$ under an argon environment $(\mathrm{a}, \mathrm{c})$ and after replacing Ar with $\mathrm{O}_{2}$ at the same temperature $(b, d)$. As expected, the replacement of the atmosphere caused an immediate and huge decrease of the $\mathrm{Ce}^{3+}$ amount (Figure $\left.1 \mathrm{a}, \mathrm{b}\right)$, but this phenomenon was also detected through $\mathrm{O}$ 1s spectra, which showed three different components.

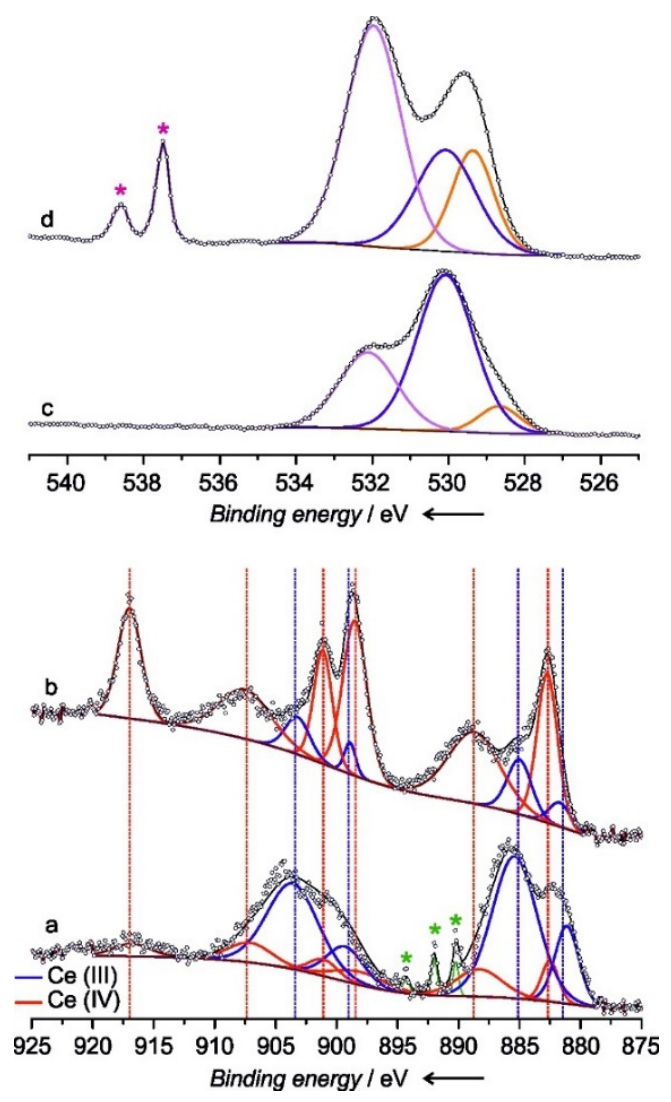

Figure 1. Ce $3 d(\mathbf{d}, \mathbf{b})$ and $\mathrm{O} 1 \mathrm{~s}$ spectra $(\mathbf{c}, \mathbf{d})$ recorded over $\mathrm{Ce}_{0.8} \mathrm{Zr}_{0.2} \mathrm{O}_{2}$-soot at $823 \mathrm{~K}$ under an argon atmosphere $(\mathbf{a}, \mathbf{c})$ and by replacing $\mathrm{Ar}$ with $\mathrm{O}_{2}(\mathbf{b}, \mathbf{d})$. Reprinted with permission from [135], copyright 2016, Wiley Online Library.

The bands at 528.7 and $530.2 \mathrm{eV}$ of binding energy (Figure 1c,d) were attributed to ceria lattice oxygen and surface oxygen atoms with low coordination due to vacancy formation, respectively, and the peak at higher binding energy $(532.2 \mathrm{eV})$ corresponded to superoxide species. When the argon gas phase was replaced by $\mathrm{O}_{2}$, cerium oxide reoxidised and the $\mathrm{O} 1 \mathrm{~s}$ band of the surface oxygen associated to $\mathrm{Ce}^{3+}$, located at $530.2 \mathrm{eV}$, decreased its intensity (Figure 1d). Concurrently, the signal at $532.2 \mathrm{eV}$ attributed to superoxide species appeared noticeably intense, demonstrating that these active oxygen species resulted from the reaction between molecular $\mathrm{O}_{2}$ and oxygen vacancies. Therefore, the NAP-XPS technique allowed Soler and co-workers to demonstrate that soot oxidation over ceria-based materials involved a two-way cooperative mechanism: on one side, the formation of oxygen vacancies and $\mathrm{Ce}^{3+}$ species at the ceria-soot interface and, on the other side, the oxidation of the surface of soot by active superoxide species, generated from the reaction between the oxygen vacancies and gaseous $\mathrm{O}_{2}$. Both routes occurred simultaneously and mutually strengthen each other. 


\subsection{4. $\mathrm{CO}_{2}$ Hydrogenation}

Nowadays, the synthesis of methanol from $\mathrm{CO}_{2}$ is receiving strong attention [206-210] not only as a strategy to abate this greenhouse pollutant but also due to the potential use of $\mathrm{CO}_{2}$ as an alternative source of carbon. The conversion of $\mathrm{CO}_{2}$ to a valuable commodity such as synthesis gas $\left(\mathrm{CO}+\mathrm{H}_{2}\right)$, hydrocarbon compounds ( $\mathrm{CH}_{4}$, olefins) and oxygenates (alcohols, ethers, acids) is, thus, highly desirable and numerous reports have appeared recently [206,211-215]. However, the activation of $\mathrm{CO}_{2}$ is a challenging task due to the inconveniences related to the chemical inertness of $\mathrm{CO}_{2}$. [207-210]. Currently, there is a particular resurgence in the study of $\mathrm{CO}_{2}$ hydrogenation to $\mathrm{Cl}$ and higher alcohols $\left(\mathrm{xCO}_{2}+\mathrm{yH}_{2} \rightarrow \mathrm{C}_{\mathrm{x}} \mathrm{H}_{3} \mathrm{OH}\right.$ $+\mathrm{xH}_{2} \mathrm{O}$ ) [216-219], a process which is mainly associated with supported Cu-based catalysts with a $\mathrm{Cu} / \mathrm{ZnO} / \mathrm{Al}_{2} \mathrm{O}_{3}$ formulation $[217,220,221]$. Many research groups have investigated the optimization of the configuration of metal-oxide catalysts to activate $\mathrm{CO}_{2}$ and convert it into valuable chemicals, and they found an improvement in the catalytic activity of $\mathrm{Cu}$ (which interacts very poorly with $\mathrm{CO}_{2}$ on its own) $[207,209,222]$ upon dispersing this metal on a $\mathrm{ZnO}$ substrate. Moreover, recent studies have identified the presence of $\mathrm{ZnO}_{\mathrm{x}}$ aggregates on top of $\mathrm{Cu}$ particles of a conventional $\mathrm{Cu} / \mathrm{ZnO}$ catalyst active for methanol synthesis $[220,223,224]$. Graciani and co-workers presented a completely different catalyst formulation for $\mathrm{CO}_{2}$ activation: a copper-ceria interface, which was highly active for methanol synthesis [136]. Approximately $0.2 \mathrm{ML}$ of $\mathrm{CeO}_{\mathrm{x}}$ nanoparticles were deposited onto $\mathrm{Cu}(111)$, and the combination of NAP-XPS and ambient pressure infrared reflection absorption spectroscopy (AP-IRRAS) allowed the identification of adsorbed $\mathrm{CO}_{2}{ }^{{ }^{-}-}$species on the surface of the $\mathrm{CeO}_{\mathrm{x}} / \mathrm{Cu}(111)$ catalyst under a $\mathrm{CO}_{2} / \mathrm{H}_{2}$ mixture ( 0.39 total mbar). $\mathrm{C} 1 \mathrm{~s}$ spectrum presented a weak feature at $\sim 284 \mathrm{eV}$, corresponding to a very small amount of $\mathrm{C}$ deposited on the surface of the catalyst because of the complete decomposition of $\mathrm{CO}_{2}$. However, the spectrum was dominated by a main feature, which could be fitted with two bands at 289.2 and $288.4 \mathrm{eV}$, attributed to formate and carboxylate species, respectively. The former band was more intense than the band associated to $\mathrm{CO}_{2}{ }^{\delta-}$ species, denoting the high stability of formates, which may not be efficient as intermediate species in the $\mathrm{CO}_{2}$ to $\mathrm{CH}_{3} \mathrm{OH}$ conversion. With this work, Graciani et al. demonstrated that the metal-oxide interface generated by combining $\mathrm{CeO}_{\mathrm{x}}$ nanoparticles with $\mathrm{Cu}(111)$ provided adsorption/reaction sites for the synthesis of methanol, which would be very difficult to create on a pure metal or alloy surface. Following this work, Senanayake and colleagues compared the catalytic activity of $\mathrm{ZnO} / \mathrm{Cu}(111)$ and $\mathrm{CeO}_{\mathrm{x}} / \mathrm{Cu}(111)$ systems when modifying the coverage of the oxides on the metallic substrate [137]. Their results indicated that the catalytic activity was strongly influenced not only by the oxide coverage, but also by the nature of the oxide. Specifically, $\mathrm{CeO}_{x} / \mathrm{Cu}(111)$ was the most active catalyst among the inverse catalysts with an oxide/metal configuration, which have higher catalytic properties than conventional $\mathrm{Cu} / \mathrm{ZnO}$ and $\mathrm{Cu} / \mathrm{CeO}_{2}$ catalytic systems. Again, by combining NAP-XPS and AP-IRRAS techniques, researchers found that $\mathrm{Ce}^{3+}$ oxidation state prevailed at low coverages and provided an efficient reaction pathway to adsorb and hydrogenate $\mathrm{CO}_{2}$ through a $\mathrm{CO}_{2}{ }^{\mathrm{\delta}}$ intermediate, clearly indicating that the ceria-copper interface was essential for a high catalytic activity in the methanol synthesis.

A completely different catalyst configuration was investigated during $\mathrm{CO}_{2}$ hydrogenation by Lin et al. [97], who prepared copper-ceria catalysts using different nanostructured ceria supports: nanorods $\left(\mathrm{Cu} / \mathrm{CeO}_{2}-\mathrm{NR}\right)$ and nanospheres $\left(\mathrm{Cu} / \mathrm{CeO}_{2}-\mathrm{NS}\right)$. By means of NAP-XPS and other techniques, they found that copper-ceria catalysts produced primarily $\mathrm{CO}$ at atmospheric pressures through the reverse water-gas shift (RWGS) reaction and a negligible amount of methanol. $\mathrm{Cu} / \mathrm{CeO}_{2}-\mathrm{NR}$ catalyst displayed a higher activity, which provides direct evidence of the morphological effect of ceria support on catalytic performance. Time-resolved X-ray diffraction (TR-XRD) and NAP-XPS measurements showed important oxidation state changes of the catalysts under reaction conditions, being metallic $\mathrm{Cu}$ and partially reduced ceria the active phase for the reaction. Studies with NAP-XPS also revealed a more effective $\mathrm{CO}_{2}$ dissociative activation at high temperature and a preferential formation of bidentate carbonate and formate intermediates over ceria nanorods, which mainly expose (110) terminations. Finally, Winter and colleagues [138] reported a study of $\mathrm{CO}_{2}$ hydrogenation over $\mathrm{CeO}_{2}$-supported $\mathrm{Ni}$ catalysts with different metal loading. Their NAP-XPS measurements revealed that the oxidation state 
of $\mathrm{Ni}$ remained metallic under reaction conditions for all metal loadings $(0.5-5 \mathrm{wt} \% \mathrm{Ni})$, which implies that the Ni chemical state at the surface of the catalysts does not explain the selectivity differences. For all tested catalysts, ceria support appeared partially reduced under reducing conditions and also upon exposure to $\mathrm{CO}_{2}$ and $\mathrm{H}_{2}$ mixture, suggesting that oxygen from carbon dioxide did not reoxidise the $\mathrm{CeO}_{\mathrm{x}}$ and consistent with the assumption that a mixture of $\mathrm{Ce}^{3+}$ and $\mathrm{Ce}^{4+}$ oxidation states plays a role in $\mathrm{CO}_{2}$ activation.

\subsubsection{Hydrocarbons}

Natural gas, mainly composed of methane, is abundantly found in many large deposits around the word. However, most of it is located in remote zones and needs to be transported across wide distances before engaging in trade. Methane conversion to more useful and readily transferable chemicals has therefore become a primary issue for the chemistry society and has been extensively investigated during the last 30 years, and synthesis gas is the most economically available route known to date $[225,226]$. Depending on the purpose of industrial application, several syngas production routes from methane are available, some of them described below.

\section{Methane Partial and Complete Oxidation}

The catalytic partial oxidation of methane (MPO) to syngas $\left(\mathrm{CO}+\mathrm{H}_{2}\right)$ is a slightly exothermic reaction first suggested in 1929 by Liander [227], who investigated it for the ammonia process. As high methane conversion and syngas selectivity are achieved at short contact times, this reaction can be used to transform methane, the main constituent of natural gas, into syngas in small-medium scale plants, e.g., to produce it for distribution [228-233]. In the past decades, many groups have studied the production of syngas via MPO using $\mathrm{Ni}$, $\mathrm{Co}$ and noble metals supported on reducible oxides such as $\mathrm{Al}_{2} \mathrm{O}_{3}, \mathrm{MgAl}_{2} \mathrm{O}_{4}, \mathrm{CeO}_{2}$ and $\mathrm{ZrO}_{2}$ [234-238]. Focusing on ceria-based catalysts, $\mathrm{Zhu}$ et al. [139] examined the surface chemistries of $\mathrm{CeO}_{2}$ doped with $\mathrm{Pd}, \mathrm{Pt}$ and $\mathrm{Rh}$ during methane partial oxidation at different temperatures by means of NAP-XPS. Under the same catalytic conditions ( 2.6 and $1.3 \mathrm{mbar}$ of $\mathrm{CH}_{4}$ and $\mathrm{O}_{2}$, respectively) $\mathrm{Pt}$ and $\mathrm{Rh}$ appeared completely oxidised on the ceria surface, whereas metallic Pd nanoparticles were detected, which induced quite different catalytic activities in MPO. Among all catalysts, Rh-doped ceria exhibited the highest catalytic performance and selectivity for methane partial oxidation.

The catalytic complete oxidation of methane constitutes a decisive process to remove the unburned methane emitted from natural gas power plants or engines of vehicles using natural gas or liquefied petroleum gas as fuels. Unlike gasoline-fuelled engines, engines using natural gas or liquefied petroleum gas combust at relatively low temperatures, typically lower than $873 \mathrm{~K}$ [239]. Therefore, a catalyst which is highly active below $873 \mathrm{~K}$ for complete transformation of methane into $\mathrm{CO}_{2}$ is required to remove the unburned methane or short-chain hydrocarbons in the exhaust line before releasing it into the environment, since $\mathrm{CH}_{4}$ is a much stronger greenhouse pollutant than $\mathrm{CO}_{2}$ [240-243]. Noble metal-based catalysts such as supported $\mathrm{Pd}$ and Pt have been extensively investigated, owing to their high catalytic activity for complete oxidation of methane at relatively low temperature [244-247]. However, they are limited to any use at large scale due to their restrictively high cost, extremely low abundance in earth and prompt deactivation of catalysts caused by sintering of supported noble metal nanoparticles. To improve the lifetime of noble metal-based catalysts and decrease their price, dispersion of nanoparticles on high surface-area oxide is used. In this sense, ceria is an important support in oxidative catalysis owing to its high activity in molecular $\mathrm{O}_{2}$ activation [3]. With this aim, Dou et al. [140] prepared a $\mathrm{Co}_{3} \mathrm{O}_{4} / \mathrm{CeO}_{2}$ nanocomposite catalyst that consisted of $\mathrm{Co}_{3} \mathrm{O}_{4}$ nanoparticles supported on ceria nanorods, and investigated its surface during complete oxidation of $\mathrm{CH}_{4}$ (flowing mixture of $0.26 \mathrm{mbar} \mathrm{CH}_{4}$ and $1.33 \mathrm{mbar}_{2}$ ) in the temperature range of $423-773 \mathrm{~K}$ with near-ambient XPS. Kinetic studies of pure $\mathrm{CeO}_{2}$, pure $\mathrm{Co}_{3} \mathrm{O}_{4}$ and $\mathrm{Co}_{3} \mathrm{O}_{4} / \mathrm{CeO}_{2}$ catalysts were first performed to calculate the different activation energies for complete oxidation of methane, and the results suggested a synergetic effect between both oxides since the nanocomposite catalyst exhibited lower activation 
energy than that of pure ceria and cobalt oxide. As for NAP-XPS studies, $\mathrm{C} 1 \mathrm{~s}$ spectra allowed the identification of a stable intermediate methyl species formed on the surface of $\mathrm{Co}_{3} \mathrm{O}_{4} / \mathrm{CeO}_{2}$ during catalysis, which could be generated through dissociation of $\mathrm{C}-\mathrm{H}$ of methane on $\mathrm{Ce}^{4+}, \mathrm{Co}^{3+}$ or $\mathrm{Co}^{2+}$ sites, since no oxygen vacancies were formed and detected on the cerium oxide support. Very similar results were obtained by Zhang and co-workers [141], who prepared $\mathrm{CeO}_{2}$ nanorods with supported $\mathrm{NiO}$ nanoclusters of 10-12 nm average size and studied them under the same methane complete oxidation conditions as the work of Dou and colleagues [140]. Tracking the evolution of C 1s NAP-XPS features with increasing temperature under reaction conditions, they deduced the formation of a stable $\mathrm{CH}_{3}$-like intermediate bound to the Ni cation at $423-473 \mathrm{~K}$. The generated surface $\mathrm{CH}_{3}$ could be further activated to form $\mathrm{CH}_{2}$ or even $\mathrm{CH}$ species, which in turn could combine with surface lattice oxygen atoms to form $\mathrm{CO}_{2}$ and $\mathrm{H}_{2}$.

Dry Reforming of Hydrocarbons

Natural gas and biogas, composed mainly of methane, have become cheap and abundant alternatives to traditional fossil fuels such as petroleum and coal [248]. They can be combusted with oxygen for the production of electricity or heat, but they can also be used as a carbon source in the manufacture of commodity chemicals [249]. This can be achieved by means of reforming methane to synthesis gas $\left(\mathrm{CO} / \mathrm{H}_{2}\right)$ and subsequently using syngas in industrial processes such as methanol synthesis, ammonia synthesis, hydrogenations or Fischer-Tropsch (FT) reactions [250,251]. There are three oxidative routes to generate syngas from methane: partial oxidation (Equation (2)), steam reforming (Equation (3)) and dry reforming (Equation (4)).

$$
\begin{gathered}
2 \mathrm{CH}_{4}+\mathrm{O}_{2} \rightarrow 4 \mathrm{H}_{2}+2 \mathrm{CO} ; \Delta \mathrm{H}_{298}=-71 \mathrm{~kJ} / \mathrm{mol}, \\
\mathrm{CH}_{4}+\mathrm{H}_{2} \mathrm{O} \rightarrow 3 \mathrm{H}_{2}+\mathrm{CO} ; \Delta \mathrm{H}_{298}=206 \mathrm{~kJ} / \mathrm{mol}, \\
\mathrm{CH}_{4}+\mathrm{CO}_{2} \rightarrow 2 \mathrm{H}_{2}+2 \mathrm{CO} ; \Delta \mathrm{H}_{298}=246 \mathrm{~kJ} / \mathrm{mol},
\end{gathered}
$$

Although dry reforming of methane (DRM) is the most difficult of these processes, it is attractive as an initial step in the Fischer-Tropsch reaction and methanol synthesis, due to its $\mathrm{CO}: \mathrm{H}_{2}=1: 1$ production ratio [252,253]. Additionally, dry reforming of methane is a desirable process since it converts two active greenhouse gases $\left(\mathrm{CO}_{2}\right.$ and methane) into syngas, representing a promising approach to mitigate problems caused by global emissions [254,255]. The high stability of $\mathrm{C}-\mathrm{H}$ bonds of methane makes its activation difficult [256], and the extraction of oxygen from $\mathrm{CO}_{2}$ entails a large activation barrier [249]. Therefore, enabling low-temperature activation of methane is a major technological goal, and a detailed investigation of the DRM through in situ techniques will help to obtain a better understanding of the reaction mechanism for the selective $\mathrm{CH}_{4}$ activation by evading pathways to complete oxidation. Typically, pure noble metals (e.g., $\mathrm{Pt}, \mathrm{Pd}, \mathrm{Rh}, \mathrm{Ru}$, and $\mathrm{Ir}$ ) are highly active for this reaction, but at elevated temperatures suffer from rapid deactivation by particle sintering and chemical poisoning (carbon deposition) [257-259]. Late transition metals such as Ni, Co and Fe represent an alternative option owing to its low cost and higher abundance [260,261]. Again, the dispersion of nanoparticles of these metals on oxide surfaces is an attractive option as a catalyst for the DRM process.

Among all the formulations, the inexpensive $\mathrm{Ni} / \mathrm{Al}_{2} \mathrm{O}_{3}$ is the most widely used catalyst for this reaction, although research is still required in order to diminish its deactivation by carbon formation and improve the whole process. Ceria is also an excellent candidate as a support to improve the catalytic performance of nickel in these reforming reactions, particularly due to the SMSI between the oxide and the deposited metals [262]. Precisely, Gonzalez-Delacruz et al. prepared a $\mathrm{Ni} / \mathrm{CeO}_{2}$ catalyst in order to study its behaviour in the dry reforming of methane with the use of various in situ techniques, such as X-ray absorption spectroscopy (XAS) and NAP-XPS [142]. The sample was subjected to different treatments at $923 \mathrm{~K}$, the highest achievable temperature with their near-ambient XPS apparatus. Under 
1.33 mbar DRM conditions $\left(\mathrm{CH}_{4} / \mathrm{CO}_{2}\right.$ mixture), $\mathrm{Ce} 4 \mathrm{~d}$ spectra of the catalyst presented no changes with respect to the fresh sample, but when it was submitted to a pure methane treatment at the same temperature, important changes appeared in the profile of $\mathrm{Ce} 4 \mathrm{~d}$ spectra, revealing an almost complete reduction of the ceria surface to $\mathrm{Ce}^{3+}$ species. The original signal was not entirely recovered after subsequent treatment with pure $\mathrm{CO}_{2}$, indicating the presence of a $\mathrm{Ce}^{3+}$ and $\mathrm{Ce}^{4+}$ mixture on the surface of the support. This opposition to be reoxidised was most probably caused by the deposition of carbon on the catalyst, which could be observed by scanning electron microscopy (SEM) after the DRM reaction. The same catalyst formulation was studied by Liu and co-workers [143], although they prepared a model $\mathrm{Ni} / \mathrm{CeO}_{2}$ catalyst which contained $\sim 2 \mathrm{~nm}$ size $\mathrm{NiO}$ nanoparticles dispersed on a $\mathrm{CeO}_{2-\mathrm{x}}(111)$ substrate. After annealing the sample at $500 \mathrm{~K}$, some $\mathrm{Ni}$ particles sintered and a large fraction of $\mathrm{Ni}$ migrated into the ceria support, forming a $\mathrm{Ce}_{1-\mathrm{x}} \mathrm{Ni}_{\mathrm{x}} \mathrm{O}_{2-\mathrm{y}}$ solid solution. In this case, they investigated the interaction of $\mathrm{CH}_{4}, \mathrm{CO}_{2}$ and a $\mathrm{CH}_{4} / \mathrm{CO}_{2}$ mixture with model $\mathrm{CeO}_{2}(111)$ and $\mathrm{Ni} / \mathrm{CeO}_{2}(111)$ surfaces (in a temperature range of 300-700 K) with NAP-XPS to better understand the chemistry of the DRM process on this type of catalyst. Under a pressure of 0.13 mbar of methane, the bands that appeared in the $\mathrm{C} 1 \mathrm{~s}$ region at $300 \mathrm{~K}$ indicate that methane dissociates on the $\mathrm{Ni} / \mathrm{CeO}_{2}$ surface at room temperature. When the first hydrogen atom is removed from methane molecules, they quickly dissociate and a $\mathrm{CH}_{3} \rightarrow \mathrm{CH}_{2} \rightarrow \mathrm{CH} \rightarrow \mathrm{C}$ transformation occurs on the catalyst surface, generating $\mathrm{C}$ atoms that ultimately react with ceria lattice oxygen atoms to result in gaseous $\mathrm{CO}$ and adsorbed $\mathrm{CO}_{x}$ species, the latter ones were evidenced by a strong band near $290.2 \mathrm{eV} \mathrm{[39].} \mathrm{Weak}$ features at $285-286 \mathrm{eV}$ were probably originated by $\mathrm{CH}_{\mathrm{x}}$ species on the surface. However, at higher temperatures, $\mathrm{CO}_{\mathrm{x}}$ and $\mathrm{CH}_{\mathrm{x}}$ features no longer appeared in the $\mathrm{C} 1 \mathrm{~s}$ region. The corresponding spectrum for the $\mathrm{Ce} 4 \mathrm{~d}$ and $\mathrm{Ni} 3 \mathrm{p}$ regions did not show evident signs of modifications of $\mathrm{Ce}^{4+}$ and $\mathrm{Ni}^{2+}$ oxidation states between $300-500 \mathrm{~K}$, but at $700 \mathrm{~K}$ their line shape clearly changed, denoting the reduction of both phases to $\mathrm{Ce}^{3+}$ and $\mathrm{Ni}^{0}$. The amount of $\mathrm{Ce}^{3+}$ species formed on a plain $\mathrm{CeO}_{2}(111)$ surface at temperatures above $600 \mathrm{~K}$ was much smaller than that on a $\mathrm{Ni} / \mathrm{CeO}_{2}(111)$ surface under similar conditions. Under 0.13 mbar of $\mathrm{CO}_{2}$, a strong feature for adsorbed $\mathrm{CO}_{\mathrm{x}}$ species at $290.2 \mathrm{eV}$ dominated the $\mathrm{C} 1 \mathrm{~s}$ XPS spectrum for both $\mathrm{CeO}_{2}(111)$ and $\mathrm{Ni} / \mathrm{CeO}_{2}(111)$ surfaces, but disappeared upon heating the samples to 500 or $700 \mathrm{~K}$. Additionally, no change in the oxidation state of $\mathrm{Ce}^{4+}$ and $\mathrm{Ni}^{2+}$ species was observed at any temperature. Therefore, the reactivity of the system towards $\mathrm{CO}_{2}$ was not affected by the addition of nickel to $\mathrm{CeO}_{2}(111)$.

Under an atmosphere of $0.26 \mathrm{mbar}^{\mathrm{CH}} \mathrm{H}_{4}$ and $\mathrm{CO}_{2}$ at $300 \mathrm{~K}$, the $\mathrm{C} 1$ s region of the $\mathrm{Ni} / \mathrm{CeO}_{2}(111)$ catalyst exhibited a $\mathrm{CO}_{\mathrm{x}}$ band near $290.2 \mathrm{eV}$ with enhanced intensity, due to the presence of both gaseous reactants, as well as peaks of adsorbed $\mathrm{CH}_{\mathrm{x}}$ species $(285-286 \mathrm{eV})$ and $\mathrm{CH}_{4}$ and $\mathrm{CO}_{2}$ gas phases (see Figure 2). The signals for adsorbed $\mathrm{CO}_{\mathrm{x}}$ and $\mathrm{CH}_{\mathrm{x}}$ species disappeared when the sample was heated from 300 to $500 \mathrm{~K}$. When heating to $700 \mathrm{~K}$, the spectrum showed features for gaseous $\mathrm{CO}$ and surface $\mathrm{CO}_{x}$ species in addition to the signals for the reactants, as illustrated in Figure 2. Below $700 \mathrm{~K}$, the surface of the catalyst was mainly composed of $\mathrm{Ni}^{2+}$ and $\mathrm{Ce}^{4+}$ species, and no catalytic activity was observed. Nevertheless, at $700 \mathrm{~K}$ the system became catalytically active when the decomposition products of methane generated $\mathrm{Ni}^{0}$ and partially reduced $\mathrm{Ce}^{4+}$ to $\mathrm{Ce}^{3+}$. Under a $\mathrm{CH}_{4} / \mathrm{CO}_{2}$ mixture, the $\mathrm{Ce}^{3+}$ fraction generated was again much smaller than under pure methane due to the presence of $\mathrm{CO}_{2}$ in the gas phase, which reacts with the ceria surface and recovers a significant amount of the oxygen vacancies, $\mathrm{CO}_{2}(\mathrm{~g})+\mathrm{Vac} \rightarrow \mathrm{CO}(\mathrm{a})+\mathrm{O}-\mathrm{Vac}$. Moreover, the $\mathrm{C}$ formed by total dissociation of methane did not react with ceria lattice oxygen atoms but with the $\mathrm{O}$ adatoms generated by the decomposition of $\mathrm{CO}_{2}$ instead.

Following this work, Lustemberg et al. published an investigation related to the effect of Ni coverage on the performance of the same $\mathrm{Ni} / \mathrm{CeO}_{2}(111)$ catalyst for dry reforming of methane [144]. Although they only performed NAP-XPS experiments for a system with low Ni content $\left(\Theta_{\mathrm{Ni}} \sim 0.1 \mathrm{ML}\right)$ to avoid the formation of $\mathrm{NiC}_{\mathrm{x}}, \mathrm{Ni} / \mathrm{CeO}_{2}(111)$ surfaces with $\mathrm{Ni}$ coverages from $0.15 \mathrm{ML}$ to $0.5 \mathrm{ML}$ were studied by multiple characterization techniques. The obtained results revealed that ceria surfaces with a small coverage of $\mathrm{Ni}$ are able to activate methane at room temperature, generating adsorbed $\mathrm{CO}_{x}$ and $\mathrm{CH}_{x}$ 
species. In other words, Ni coverage on ceria substrate extremely determines metal-support interactions, which are in turn responsible for the low barrier for $\mathrm{C}-\mathrm{H}$ bond cleavage of methane on this metal/oxide system. To complete the investigation, Liu and co-workers studied the metal-oxide interactions of a series of metal $/ \mathrm{CeO}_{2}(111)$ (metal $=\mathrm{Co}, \mathrm{Ni}$ and $\mathrm{Cu}$ ) under DRM conditions at relatively low temperatures $(600-700 \mathrm{~K})$ [146]. The behaviour of $\mathrm{Co}, \mathrm{Ni}$ and $\mathrm{Cu}$ on a $\mathrm{CeO}_{2}(111)$ substrate (with a coverage of $0.2 \mathrm{ML}$ ) was first compared using conventional XPS and kinetic testing, as well as theoretical calculations based on DFT. Among the systems examined in a temperature range of $300-700 \mathrm{~K}, \mathrm{Co} / \mathrm{CeO}_{2}(111)$ exhibited the best catalytic performance for dry reforming of methane, whereas $\mathrm{Cu} / \mathrm{CeO}_{2}(111)$ had negligible activity. Catalytic tests were in agreement with in situ XPS measurements performed to study their ability to activate pure $\mathrm{CH}_{4}$, which showed that the surface with cobalt reduced the most and, consequently, reacted better with methane than $\mathrm{Ni} / \mathrm{CeO}_{2}(111)$ or $\mathrm{Cu} / \mathrm{CeO}_{2}(111)$ catalysts. Indeed, the partial reduction of ceria support is essential for the activation of both reactants. Operando XPS was then employed to study the chemical changes in the best $\mathrm{Co} / \mathrm{CeO}_{2}(111)$ catalyst under reaction conditions $\left(\mathrm{CH}_{4} / \mathrm{CO}_{2}\right.$ mixture), and experiments indicated that methane dissociates on the ceria support with $0.2 \mathrm{ML}$ of $\mathrm{Co}$ at temperatures as low as $300 \mathrm{~K}$, generating $\mathrm{CH}_{\mathrm{x}}$ and $\mathrm{CO}_{\mathrm{x}}$ species on the surface. Both ceria and $\mathrm{Co}^{2+}$ appeared partially reduced at $500-700 \mathrm{~K}$, but at $700 \mathrm{~K}$ and under DRM conditions, $\mathrm{CO}_{2}$ dissociates on the oxide surface and slightly reoxidises $\mathrm{Co}$ and $\mathrm{Ce}^{3+}$, establishing a catalytic cycle without coke deposition. Additionally, catalytic activity for $\mathrm{C} 2$ production was also observed at $650 \mathrm{~K}$, since a significant part of the adsorbed $\mathrm{CH}_{\mathrm{x}}$ species recombined to yield ethane and ethylene. Catalytic activity of the $\mathrm{Co} / \mathrm{CeO}_{2}(111)$ catalyst for DRM and ethane/ethylene production was also examined as a function of cobalt coverage, and they observed a maximum at a coverage of approximately $0.15 \mathrm{ML}$ and $0.1 \mathrm{ML}$ for syngas and ethane/ethylene production, respectively. Therefore, not only the nature of the metal is crucial for the catalyst DRM activity and stability, but also the preservation of a low metal loading (below $0.2 \mathrm{ML}$ ), since at higher loadings carbon is formed on the surface leading to catalyst deactivation.
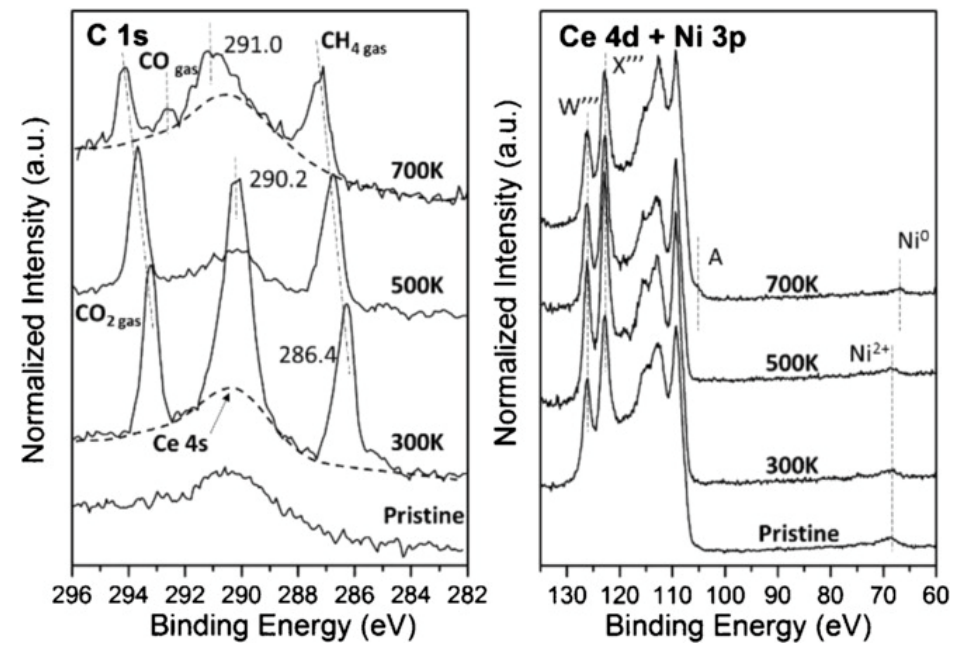

Figure 2. $\mathrm{C} 1 \mathrm{~s}$ and $\mathrm{Ce} 4 \mathrm{~d}+\mathrm{Ni} 3 \mathrm{p}$ spectra of the $\mathrm{Ni} / \mathrm{CeO}_{2}(111)$ catalyst $\left(\Theta_{\mathrm{Ni}} \sim 0.1 \mathrm{ML}\right)$ surface under 0.13 mbar $\mathrm{CH}_{4}$ and 0.13 mbar $\mathrm{CO}_{2}$ at different temperatures. Reprinted with permission from [143], copyright 2016, Wiley Online Library.

In another report, Zhang et al. also investigated the dry reforming of methane over a series of ceria-supported powder catalysts with different cobalt loadings $(2-30 \mathrm{wt} \%)$ in order to elucidate the interaction between $\mathrm{Co}$ and $\mathrm{CeO}_{2}$ during the catalytic process, and thus optimise the design of a catalyst with improved activity [147]. Various in situ techniques were used to achieve so, such as in situ time-resolved XRD (TR-XRD). Their results showed a huge reduction of the $\mathrm{CoO}_{x}-\mathrm{CeO}_{2}$ system at temperatures between 473 and $623 \mathrm{~K}$ as a consequence of the hydrogen produced by the dissociation of $\mathrm{C}-\mathrm{H}$ bonds in methane, which fully converted the $\mathrm{Co}_{3} \mathrm{O}_{4}$ oxide to metallic $\mathrm{Co}$ and partially reduced $\mathrm{Ce}^{4+}$ to $\mathrm{Ce}^{3+}$. A catalytic cycle for DRM was achieved on the catalysts upon dosing $\mathrm{CO}_{2}$, at temperatures 
below $773 \mathrm{~K}$. Among the different Co loaded catalysts, the $10 \mathrm{wt} \% \mathrm{Co} / \mathrm{CeO}_{2}$ catalyst appeared to have the highest catalytic performance, exhibiting desirable stability for the DRM process with the lowest effect of coke accumulation. For this reason, and since TR-XRD is a primarily bulk-sensitive technique, the surface of the $10 \mathrm{wt} \% \mathrm{Co} / \mathrm{CeO}_{2}$ sample was also examined under reaction conditions with NAP-XPS. As depicted in Figure 3, results showed a dynamic evolution in the oxidation state of the catalyst under reaction conditions. The partial reoxidation of ceria upon switching the $\mathrm{H}_{2}$ reducing atmosphere to a $\mathrm{CH}_{4} / \mathrm{CO}_{2}$ mixture is evident at room temperature since $\mathrm{Ce}^{3+}$ features at the $\mathrm{Ce} 3 \mathrm{~d}$ region attenuate and the bands of $\mathrm{Ce}^{4+}$ species become more intense. A temperature increase led to a further reduction of ceria, as seen in Figure 3, although $\mathrm{CO}_{2}$ weakened the reducing effects of methane. As expected, the initial $\mathrm{Co}_{3} \mathrm{O}_{4}$ phase was completely reduced to metallic $\mathrm{Co}$ after the $\mathrm{H}_{2}$ pretreatment. When the atmosphere was changed to DRM conditions, a small amount of cobalt reoxidised, but it remained mainly $\mathrm{Co}^{0}$ as the reaction advanced to $773 \mathrm{~K}$. Analyses of the $\mathrm{O} 1 \mathrm{~s}$ region allowed the detection of $\mathrm{CO}_{\mathrm{x}}$ species (e.g., carbonate, carboxyl, bicarbonate) adsorbed on the catalyst surface, ascribing $\mathrm{CO}_{x}$ as a possible reaction intermediate.

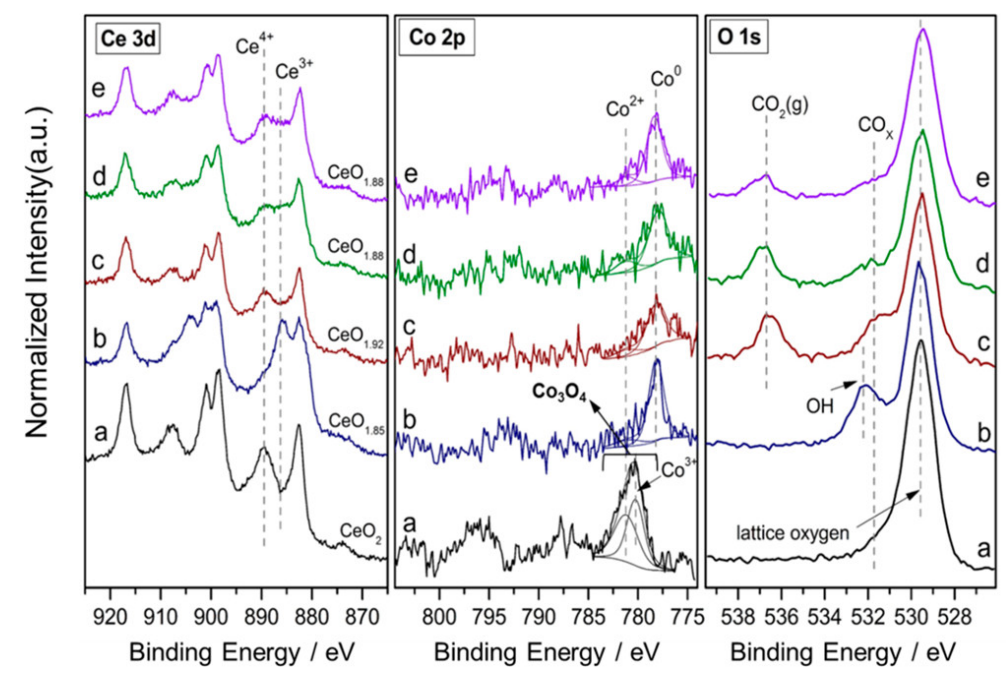

Figure 3. NAP-XPS spectra of the $\mathrm{Ce} 3 \mathrm{~d}$, $\mathrm{Co} 2 \mathrm{p}$ and $\mathrm{O} 1 \mathrm{~s}$ regions of $10 \mathrm{wt} \% \mathrm{Co} / \mathrm{CeO} 2$ catalyst (a) as prepared at $300 \mathrm{~K},(\mathbf{b})$ cooled to $300 \mathrm{~K}$ after $1 \mathrm{~h}$ of $\mathrm{H}_{2}$ pretreatment at $823 \mathrm{~K}$ and during the dry reforming of methane (DRM) reaction ( 0.1 mbar of $\mathrm{CH}_{4}+\sim 0.1 \mathrm{mbar}$ of $\left.\mathrm{CO}_{2}\right)$ : (c) at $300 \mathrm{~K}$, (d) $673 \mathrm{~K}$ and (e) 773 K. Reprinted with permission from [147], copyright 2018, American Chemical Society.

Xie and colleagues [148] also investigated the activity for DRM of a cobalt-based catalyst; they prepared a $\mathrm{PtCo} / \mathrm{CeO}_{2}$ bimetallic catalyst and compared it with the corresponding monometallic ones to explore the Pt-Co synergy for DRM. As in situ XRD, DRIFTS and XAFS analyses provided bulk-averaged structural information, NAP-XPS experiments were performed for the bimetallic sample to obtain surface information during reaction conditions. Again, the results revealed a dynamic evolution in the chemical composition of the catalyst surface: upon exposure to the reactant stream, both $\mathrm{Pt}$ and ceria slightly oxidised due to the presence of $\mathrm{CO}_{2}$ in the environment. With the combination of multiple techniques such as in situ XRD, TPR, in situ XAFS and DRIFTS, $\mathrm{PtCo} / \mathrm{CeO}_{2}$ sample was found to have the highest catalytic activity, and both Pt-Co alloy and isolated Co particles co-existed in its structure. Nevertheless, the Pt-Co alloy is the dominant active structure, which remained nearly metallic during the reaction.

Very recently, Liu and co-workers proposed another ceria-based catalyst formulation for dry reforming of methane by changing the nature of the supported metal, a key component in such catalytic process [149]. In their work, they reported a highly active and stable ceria-supported Ru-nanocluster $\left(<1 \mathrm{~nm}\right.$ ) catalyst (denoted as $\left.\mathrm{Ru}(\mathrm{NC})-\mathrm{CeO}_{2}\right)$ for the DRM, since Ru-based catalysts have exhibited high activity and stability against the deactivation by carbon accumulation $[257,263]$. In situ XRD 
and XAFS were used to elucidate the structure-reactivity relationship that caused the remarkable catalytic performance, whereas the surface chemistry and possible surface-active intermediates were monitored by NAP-XPS and DRIFTS. As the activation of methane is a crucial step in the DRM process, the catalyst was subjected to an atmosphere of pure methane before studying it under DRM conditions with operando XPS. Ce 3d NAP-XPS spectra evidenced a gradual reduction of ceria surface, that is, the formation of oxygen vacancies and $\mathrm{Ce}^{3+}$ species, after exposing the sample to pure $\mathrm{CH}_{4}$. Ceria reduction, which occurred at temperatures as low as $423 \mathrm{~K}$, was accompanied by reduction of $\mathrm{RuO}_{2}$, as expected. Under a mixture of $\mathrm{CH}_{4} / \mathrm{CO}_{2}$ at $423 \mathrm{~K}$, the ceria surface underwent an initial reduction, comparable to the case of methane alone, suggesting an effective activation of methane. Figure 4 illustrates the NAP-XPS spectra for the Ce $3 \mathrm{~d}$ and C $1 \mathrm{~s}+\mathrm{Ru} 3 \mathrm{~d}$ regions of the $0.5 \mathrm{wt} \%$ $\mathrm{Ru}(\mathrm{NC})-\mathrm{CeO}_{2}$ catalyst under DRM conditions. At temperatures greater than $573 \mathrm{~K}$, a relevant degree of ceria reoxidation was observed, which involved a significant dissociation of $\mathrm{CO}_{2}$ on either ceria or $\mathrm{Ru}$ sites, generating $\mathrm{O}$ adatoms and subsequently refilling the oxygen vacancies of the surface. This dual-site mechanism not only allows the direct activation of $\mathrm{CO}_{2}$ on the metal sites, but also allows the $\mathrm{O}$ adsorbed on ceria sites to assist the oxidation of surface carbon on $\mathrm{Ru}$ sites.

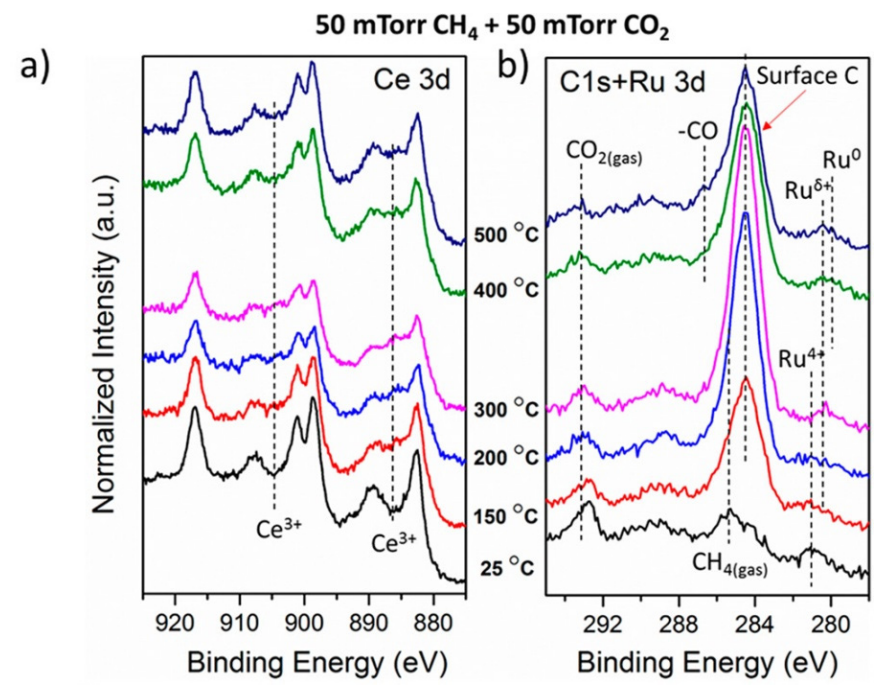

Figure 4. (a) Ce $3 \mathrm{~d}$ and (b) $\mathrm{C} 1 \mathrm{~s}+\mathrm{Ru} 3 \mathrm{~d}$ NAP-XPS spectra of the $0.5 \mathrm{wt} \% \mathrm{Ru}(\mathrm{NC})-\mathrm{CeO}_{2}$ catalyst under $\sim 0.13$ mbar $\mathrm{CH}_{4} / \mathrm{CO}_{2}$ (1:1). Reprinted with permission from [149], copyright 2019, American Chemical Society.

As depicted in Figure $4 \mathrm{~b}$, carbon deposited on the catalyst surface as the reaction developed. At $573 \mathrm{~K}$ or below, methane activation led to the formation of surface carbon on the catalyst, and at temperatures higher than $573 \mathrm{~K}$, the $\mathrm{O}$ adatoms generated from $\mathrm{CO}_{2}$ dissociation reoxidise the surface carbon due to the intimate $\mathrm{Ru}-\mathrm{O}-\mathrm{Ce}$ interaction, completing the catalytic cycle. This evolution is evidenced by a clear drop of surface carbon peak intensity, at $\sim 284.6 \mathrm{eV}$. Figure $4 \mathrm{~b}$ also revealed that under reaction conditions, the active structure of the $\mathrm{Ru}(\mathrm{NC})-\mathrm{CeO}_{2}$ catalyst was partially oxidised $\mathrm{Ru}$ clusters stabilized by reduced ceria $\left(\mathrm{Ru}^{\delta+}-\mathrm{CeO}_{2-\mathrm{x}}\right)$.

We have seen that DRM is an attractive process since it transforms two greenhouse gases $\left(\mathrm{CO}_{2}\right.$ and methane) into syngas, which can be subsequently used to produce value-added chemicals and fuels. Nevertheless, DRM is a highly endothermic reaction and demands high temperatures to achieve significant conversion. Therefore, an alternative approach to convert $\mathrm{CO}_{2}$ to syngas is the use of ethane and other light alkanes (e.g., butane) present in shale gas [264,265]. Dry reforming of ethane (DRE, Equation (5)) and dry reforming of butane (DRB, Equation (6)) generate synthesis gas through:

$$
\mathrm{C}_{2} \mathrm{H}_{6}+2 \mathrm{CO}_{2} \rightarrow 3 \mathrm{H}_{2}+4 \mathrm{CO} ; \Delta \mathrm{H}_{298}=428.1 \mathrm{~kJ} / \mathrm{mol} \text {, }
$$




$$
\mathrm{C}_{4} \mathrm{H}_{10}+4 \mathrm{CO}_{2} \rightarrow 5 \mathrm{H}_{2}+8 \mathrm{CO} ; \Delta \mathrm{H}_{298}=817.1 \mathrm{~kJ} / \mathrm{mol},
$$

Temperatures of approximately 760 and $720 \mathrm{~K}$ are required to attain the $50 \%$ conversion of $\mathrm{CO}_{2}$ in DRE and DRB, respectively, under equilibrium conditions of stoichiometric ratio. Due to the decrease of the reaction temperatures with respect to the DRM process, catalyst deactivation occurs to a lower extent and, consequently, there are more options in the design of a stable catalyst.

Yan et al. prepared model and conventional $\mathrm{PtNi} / \mathrm{CeO}_{2}$ catalysts, as well as their corresponding monometallic catalysts, and compared their catalytic performance for DRE and DRB [145]. In spite of the elevated cost of noble metal loaded catalysts (such as Pt) for large-scale processes, they commonly show higher resistance to coke accumulation and can be used to promote Ni-based catalysts so as to reduce $\mathrm{C}$ deposition and, hence, increase its lifetime. Results from both model thin films and supported powder catalysts revealed that the $\mathrm{PtNi} / \mathrm{CeO}_{2}$ bimetallic catalyst shows higher activity than the corresponding monometallic samples. In their study, multiple spectroscopic techniques, including NAP-XPS, in situ $X R D$, in situ XAFS and DRIFTS were employed to probe catalyst structures and surface intermediate species under reaction conditions. NAP-XPS measurements were performed only on model catalysts and, due to the stronger interaction of butane in comparison to ethane, only DRB was investigated with this technique. Model catalysts were prepared by depositing small coverages of PtNi, Pt or Ni (0.1 ML) onto a $\mathrm{CeO}_{2}$ film (3 ML) over a $\mathrm{TiO}_{2}$ (110) substrate, while supported catalysts were loaded with $1.7 \mathrm{wt} \%$ of $\mathrm{Pt}$ and $1.5 \mathrm{wt} \%$ of $\mathrm{Ni}$, corresponding to an atomic ratio Pt:Ni of 1:3. Under reaction conditions $(0.13 \mathrm{mbar}$ $\mathrm{CO}_{2}$ and 0.26 mbar butane), ceria substrate and metals, except for the $\mathrm{Ni}$ of $\mathrm{Ni} / \mathrm{CeO}_{2}$, were partially reduced. Interestingly, $\mathrm{Ni}$ of $\mathrm{PtNi} / \mathrm{CeO}_{2}$ catalyst was reduced to metallic nickel, which indicates that the presence of $\mathrm{Pt}$ enhances Ni reduction. In the $\mathrm{C} 1 \mathrm{~s}$ region, a band attributed to carbonate and carboxyl $\left(\mathrm{CO}_{2}{ }^{\delta-}\right)$ was observed for all catalysts, indicating the effective activation of $\mathrm{CO}_{2}$ for all three surfaces. Additionally, two more peaks appeared at 284.5 and $289.8 \mathrm{eV}$, which were assigned to the adsorbed $\mathrm{O}-\mathrm{C}_{\mathrm{x}} \mathrm{H}_{\mathrm{y}}$ species (generated from butane decomposition) and adsorbed formate, respectively. The latter was generated upon hydrogenation of adsorbed carbonate/carboxylate species. It is worth noting that each surface presented different band intensity of the adsorbed $\mathrm{O}-\mathrm{C}_{\mathrm{x}} \mathrm{H}_{\mathrm{y}}$ species, following the trend $\mathrm{PtNi} / \mathrm{CeO}_{2}>\mathrm{Ni} / \mathrm{CeO}_{2}>\mathrm{Pt} / \mathrm{CeO}_{2}$, which denoted that $\mathrm{Ni}$ is more active than $\mathrm{Pt}$, although PtNi bimetallic surface further improves butane activation.

\subsubsection{Alcohols}

The high environmental impact of fossil fuels has urged the need for alternative energy sources over the last decades. Hydrogen is being considered as the future clean and affordable fuel to be used in fuel cells or in large-scale processes such as ammonia synthesis, considering the abundant availability of $\mathrm{H}_{2}$-containing substances in nature, its high energy content $(120.7 \mathrm{~kJ} / \mathrm{g})$ and its non-polluting combustion. For this reason, fuel cell research and development have received a huge amount of funding in the last years. Among the multiple chemical carriers of hydrogen, light alcohol methanol and ethanol constitute important candidates to produce $\mathrm{H}_{2}$ via different catalytic pathways.

\section{Steam Reforming of Alcohols}

Hydrogen production from ethanol has been extensively studied, since ethanol can be obtained by the fermentation of agricultural wastes (biomass) and, therefore, constitutes a carbon-neutral renewable precursor [266,267]. Currently, catalytic research is focusing on steam reforming of ethanol (SRE), partial oxidation of ethanol (POX) and the oxidative steam reforming (OSR) as potential process candidates to produce $\mathrm{H}_{2}[267,268]$. SRE (see Equation (7)) is the most efficient pathway of renewable hydrogen production, but it is an endothermic reaction that requires an active catalyst and a sufficient energy input to obtain a high $\mathrm{H}_{2}$ yield and ethanol conversion with a reasonable reaction rate.

$$
\mathrm{C}_{2} \mathrm{H}_{5} \mathrm{OH}+3 \mathrm{H}_{2} \mathrm{O} \rightarrow 6 \mathrm{H}_{2}+2 \mathrm{CO}_{2} ; \Delta \mathrm{H}_{298}=173.3 \mathrm{~kJ} / \mathrm{mol},
$$


Generally, noble metals supported on inorganic oxides have proved to exhibit higher catalytic activity for SRE than non-noble metal-based ones [269-274]. As an alternative to expensive metals such as $\mathrm{Rh}, \mathrm{Ru}, \mathrm{Pd}$ and $\mathrm{Pt}$, non-noble metal-based catalysts $(\mathrm{Ni}, \mathrm{Co}$ and $\mathrm{Cu}$ ) have also been investigated at higher metal loadings, and they have become promising catalysts for the reaction [275-280]. The catalytic performance can also be influenced by the oxide support. Among the various metal oxides studied, ceria has exhibited a key role in reducing coke accumulation on the surface of the catalyst as well as modifying the reaction kinetics [281,282]. As already stated, the excellent performance of ceria as a support or even as a catalyst is associated to its high OSC and its rapid change between $\mathrm{Ce}^{4+}$ and $\mathrm{Ce}^{3+}$ oxidation states. Carbon deposition is mitigated on account of the transportation of oxygen species from ceria to the supported metal, which confers significantly improved catalytic activities under SRE conditions.

Bimetallic catalysts have also been studied in the SRE reaction. Divins et al. used the NAP-XPS technique to demonstrate that the presence of a reducible $\mathrm{CeO}_{2}$ support greatly influenced the surface rearrangement of bimetallic Rh-Pd nanoparticles under SRE conditions on real catalysts [68].

They performed the reaction between ethanol and water $\left(\mathrm{EtOH}: \mathrm{H}_{2} \mathrm{O}=1: 6\right)$ at $823 \mathrm{~K}$ and a sample pressure of 0.05 mbar over (a) unsupported model $\mathrm{Rh}_{0.5} \mathrm{Pd}_{0.5}$ nanoparticles (NPs) and (b) $\mathrm{Rh}_{0.5} \mathrm{Pd}_{0.5}$ NPs supported on ceria powder. Among noble metals, $\mathrm{Rh}$ is highly active for both $\mathrm{C}-\mathrm{C}$ and $\mathrm{C}-\mathrm{H}$ bond cleavage, induces hydrogenation reaction and causes very low carbon deposition [283]. Both systems were subjected to reducing, oxidising and SRE conditions to produce $\mathrm{H}_{2}$, and three different photon energies $(670,875$ and $1150 \mathrm{eV})$ were used to obtain a depth-profile study of both samples and deduce the rearrangement and the development of a core-shell structure induced by the environment. Results showed that unsupported model NPs were more strongly reduced for all the atmospheres tested. Upon reduction with $\mathrm{H}_{2}$ at $573 \mathrm{~K}$, Pd segregated towards the surface for both unsupported and supported NPs. Nevertheless, under SRE conditions at $823 \mathrm{~K}$, unsupported NPs suffered from a restructuration as $\mathrm{Rh}$ atoms migrated toward the surface and became reduced due to the reducing effect of the hydrogen produced during the ethanol steam reforming reaction. No migration of Rh or Pd was found for ceria supported NPs under ESR and, most importantly, both metals became more oxidised, as illustrated in Figure 5. Moreover, palladium developed a core-shell structure of oxidation states: as seen in Figure 5, the outer shell ( $670 \mathrm{eV}$ photon energy spectrum) of the $\mathrm{Rh}_{0.5} \mathrm{Pd}_{0.5} / \mathrm{CeO}_{2}$ catalyst exhibited a high amount of oxidised Pd species. This oxidation of the outermost layers of the supported NPs is likely due to the creation of -OH groups at the catalyst surface upon activation of water by ceria. Therefore, the interaction of the metal NPs with the support plays a crucial role in reactions catalysed by the RhPd NPs since it limits the dynamic reorganization of the metals under operating conditions ("quenching effect") and supplies active oxygen atoms to the metals at the surface of the NPs. In a deeper analysis of the same $\mathrm{Rh}_{0.5} \mathrm{Pd}_{0.5} / \mathrm{CeO}_{2}$ system, Soler et al. reported the influence of the support morphology in the reorganization of bimetallic nanoparticles, which has important consequences for catalytic performance, also by means of NAP-XPS [69]. With this aim, they monitored the surface composition and chemical states of preformed $\mathrm{Rh}_{0.5} \mathrm{Pd}_{0.5}$ model NPs of $4 \mathrm{~nm}$ size supported on two different types of nanoshaped ceria: nanocubes $\left(\mathrm{CeO}_{2}-\mathrm{c}\right)$ and nanorods $\left(\mathrm{CeO}_{2}-\mathrm{r}\right)$, during the catalytic SRE at $823 \mathrm{~K}$. Both systems were also exposed to reducing, SRE and final reducing conditions, and again three different photon energies were used to acquire the corresponding spectra and perform a depth-profile study of the bimetallic NPs under operando experiments, as previously described [68]. Under initial $\mathrm{H}_{2}$ conditions at $573 \mathrm{~K}$, both catalysts exhibited the same amount of oxidised and reduced $\mathrm{Rh}$, whereas $\mathrm{Rh}_{0.5} \mathrm{Pd}_{0.5} / \mathrm{CeO}_{2}-\mathrm{c}$ contained a larger fraction of metallic Pd than $\mathrm{Rh}_{0.5} \mathrm{Pd}_{0.5} / \mathrm{CeO}_{2}-\mathrm{r}$, which also exhibited a minor fraction of $\mathrm{Pd}^{\mathrm{IV}}$ species, almost inexistent in $\mathrm{CeO}_{2}-\mathrm{c}$. Furthermore, a core-shell structure of oxidation states of Pd was observed for the bimetallic NPs supported on $\mathrm{CeO}_{2}-\mathrm{r}$, Pd being more reduced in the inner region of the bimetallic NPs. However, the two catalysts showed completely different behaviours under SRE conditions at $823 \mathrm{~K}$ : bimetallic NPs supported on $\mathrm{CeO}_{2}$-c appeared dramatically oxidised, with predominant $\mathrm{Pd}^{4+}$ and $\mathrm{Rh}^{+} / \mathrm{Rh}^{3+}$ species, whereas Pd of bimetallic NPs supported on nanorods became more reduced with respect to 
the activation treatment under $\mathrm{H}_{2}$, with minor fractions of $\mathrm{Pd}^{2+}$ and $\mathrm{Pd}^{4+}$ species. This difference in the catalytic performance between both systems can be explained by the ability of the different exposed crystallographic planes to release oxygen atoms: indeed, oxygen vacancy formation on $\{100\}$ planes of ceria nanocubes is thermodynamically more favourable than on $\{110\}$ and $\{111\}$ planes usually found in $\mathrm{CeO}_{2}-\mathrm{r}$ and polycrystalline ceria [4]. For this reason, ceria nanocubes easily transferred oxygen atoms to the supported NPs, which resulted in their oxidation. Moreover, SRE reaction did not progress on $\mathrm{Rh}_{0.5} \mathrm{Pd}_{0.5} / \mathrm{CeO}_{2}$-c because, although ethanol can be effectively dehydrogenated into acetaldehyde and $\mathrm{H}_{2}$ over metal oxides [284], the metallic function is required for methane steam reforming, which constitutes the last step in the SRE. Additionally, NPs of both catalysts rearranged under SRE conditions at $823 \mathrm{~K}:$ Pd segregated toward the surface of the NPs supported on $\mathrm{CeO}_{2}-\mathrm{r}$, while the exact opposite ( $\mathrm{Rh}$ segregation to the surface) was observed for the $\mathrm{Rh}_{0.5} \mathrm{Pd}_{0.5} / \mathrm{CeO}_{2}-\mathrm{c}$ system. Finally, the reduction step at $823 \mathrm{~K}$ caused the reduction of the metals for both systems, but did not result in a modification of the relative distribution of $\mathrm{Pd}$ and $\mathrm{Rh}$. As for Ce $3 \mathrm{~d}$ spectra, illustrated in Figure 6, they indicated a sharp increase of $\mathrm{Ce}^{3+}$ species for both catalysts upon exposure to $\mathrm{H}_{2}$ at $823 \mathrm{~K}$, as expected. Although the $\mathrm{Ce}^{3+} / \mathrm{Ce}^{4+}$ ratio of the $\mathrm{Rh}_{0.5} \mathrm{Pd}_{0.5} / \mathrm{CeO}_{2}-\mathrm{c}$ catalyst exceeded that of $\mathrm{Rh}_{0.5} \mathrm{Pd}_{0.5} / \mathrm{CeO}_{2}$-r during the last reduction step, the latter exhibited higher $\mathrm{Ce}^{3+} / \mathrm{Ce}^{4+}$ ratio under SRE conditions with respect to $\mathrm{Rh}_{0.5} \mathrm{Pd}_{0.5} / \mathrm{CeO}_{2}-\mathrm{c}$, which was attributed to its higher hydrogen production.
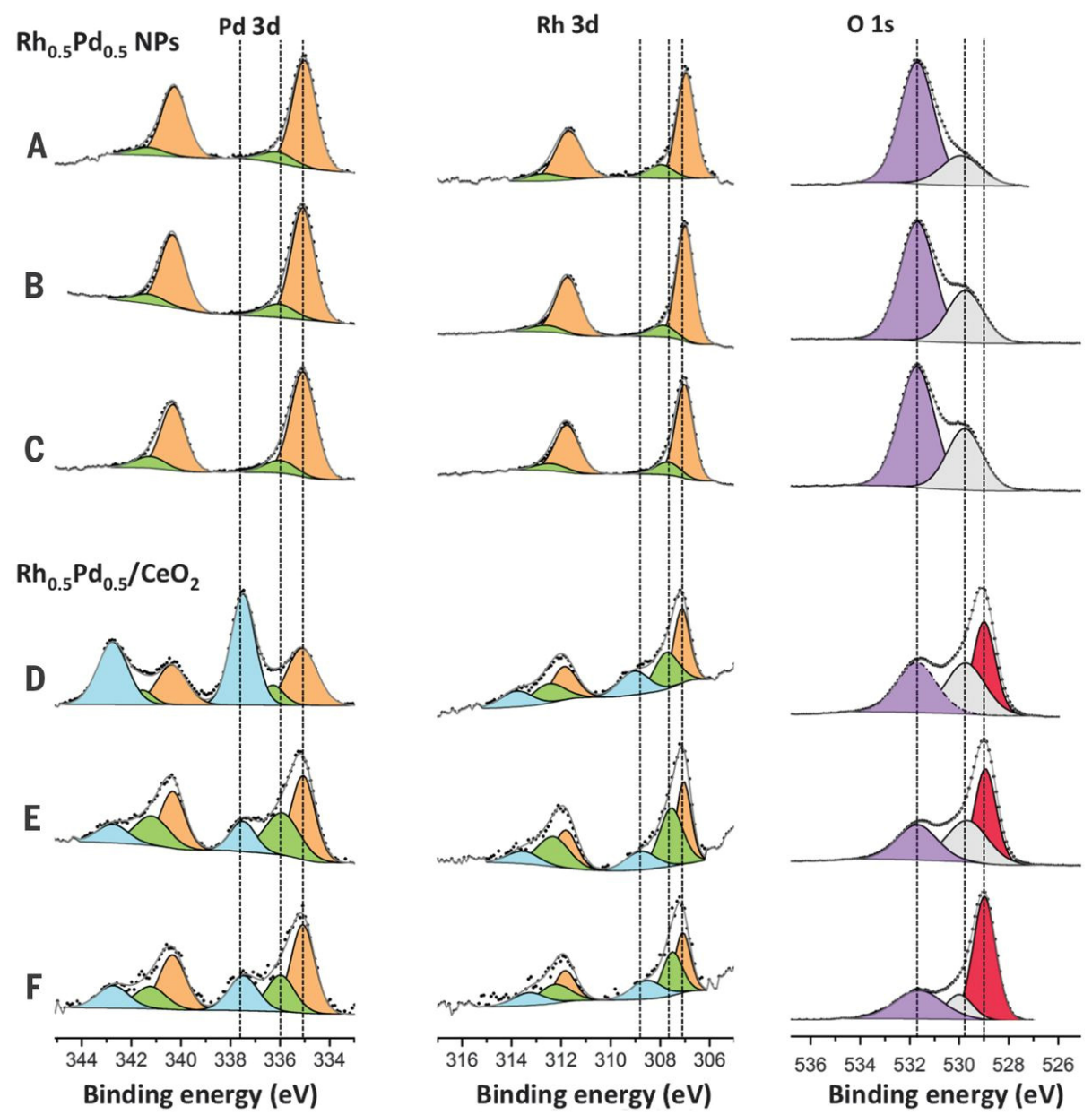

Figure 5. NAP-XPS spectra of $\mathrm{Pd} 3 \mathrm{~d}$, $\mathrm{Rh} 3 \mathrm{~d}$ and $\mathrm{O} 1 \mathrm{~s}$ recorded over model $\mathrm{Rh}_{0.5} \mathrm{Pd}_{0.5} \mathrm{NPs}$ (A to C) and $\mathrm{Rh}_{0.5} \mathrm{Pd}_{0.5} / \mathrm{CeO}_{2}$ catalyst ( $\mathbf{D}$ to $\mathbf{F}$ ) under steam reforming of ethanol (SRE) conditions at $823 \mathrm{~K}$. The photon energies used were $670 \mathrm{eV}$ (A and D), $875 \mathrm{eV}$ (B and E) and $1150 \mathrm{eV}$ (C and F). Reprinted with permission from [68], copyright 2014, Science. 


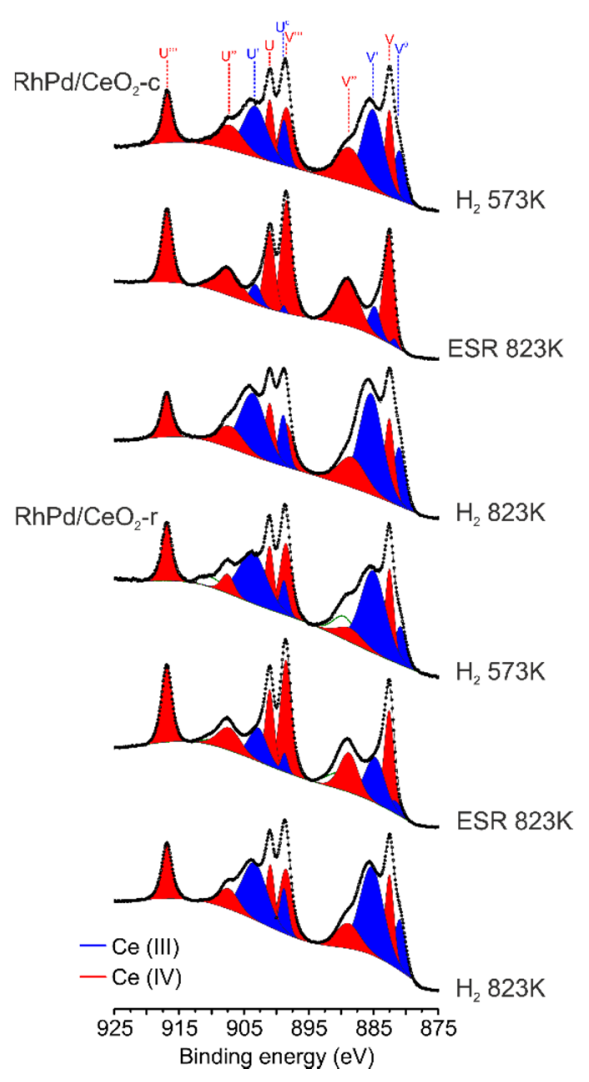

Figure 6. NAP-XPS spectra of Ce $3 d$ corresponding to $\mathrm{Rh}_{0.5} \mathrm{Pd}_{0.5} / \mathrm{CeO}_{2}$-c and $\mathrm{Rh}_{0.5} \mathrm{Pd}_{0.5} / \mathrm{CeO}_{2}-\mathrm{r}$ catalysts under different gaseous atmospheres using $1150 \mathrm{eV}$ of photon energy. Reprinted with permission from Ref [69], copyright 2019, American Chemical Society.

Among the alternatives to noble metal-based catalysts for SRE, cobalt supported catalysts are considered promising candidates for the reaction, since they have comparable activity with noble metals for $\mathrm{C}-\mathrm{C}$ bond scission in adsorbed ethanol at moderate temperatures, but considerably low prices $[276,279,284]$. Óvári et al. used NAP-XPS to study the interaction of ethanol with a well-ordered $\mathrm{CeO}_{2}$ (111) film evaporated over $\mathrm{Cu}(111)$ and with $\mathrm{Co} / \mathrm{CeO}_{2}(111) / \mathrm{Cu}(111)$ model catalyst [150]. In this case, researchers did not investigate their systems under ethanol steam reforming conditions, but simply studied the interaction of ethanol with their catalysts to determine not only the chemical nature of transient intermediates but also the oxidation states of the surface-active components. After characterizing the evaporated $\mathrm{CeO}_{2}(111)$ film on the $\mathrm{Cu}(111)$ surface, Óvári et al. investigated the adsorption and decomposition of ethanol on the oxide at $300 \mathrm{~K}$ and different pressures $\left(10^{-6}, 10^{-4}, 0.01,0.1\right.$ and $\left.1 \mathrm{mbar}\right)$. At this temperature, an increase in ethanol pressure resulted in a gradual reduction of ceria, probably via $\mathrm{H}_{2} \mathrm{O}$ desorption involving lattice oxygen atoms. However, the reduction was hindered at pressures of $10^{-4}$ mbar or higher due to a reduced mobility of either oxygen or $\mathrm{Ce}^{3+}$ centres. Ethanol adsorption at $300 \mathrm{~K}$ was also detected through the recorded $\mathrm{O} 1 \mathrm{~s}$ spectra, which at low pressures showed a shoulder at $531.5 \mathrm{eV}$ usually assigned to formation of $-\mathrm{OH}$ groups, but also possibly originated by ethoxide and acetaldehyde surface species, expected at this binding energy too $[267,285]$. At higher pressures, an additional and weak contribution at $534.3 \mathrm{eV}$ was detected, attributed to weakly held, molecularly adsorbed ethanol. Researchers also investigated the reaction of $0.1 \mathrm{mbar}$ ethanol on bare $\mathrm{CeO}_{2}(111)$ film at different temperatures (from 320 up to $600 \mathrm{~K}$ ) before cobalt deposition. During this temperature increase, the reduction of $\mathrm{Ce}^{4+}$ to $\mathrm{Ce}^{3+}$ species raised significantly, observable through Ce $3 \mathrm{~d}$ and $\mathrm{O}$ $1 \mathrm{~s} \mathrm{spectra}$. The primary intermediate, ethoxide, was again detected at all temperatures $(285.7 \mathrm{eV})$ and formed by dissociative adsorption of ethanol, and no coke deposition was observed up to $600 \mathrm{~K}$ on ceria. Upon deposition of $0.7 \mathrm{ML}$ of cobalt at $300 \mathrm{~K}$, partial reduction of ceria was observed, which also led to the formation of $\mathrm{Co}^{2+}$ sites but still leaving metallic $\mathrm{Co}$ in metal particles, suggested by the large 
width of the main peak at Co $2 p$ region. Since the reaction of cobalt and ceria is expected to develop mainly at the support/metal interface, the small amounts of unreacted $\mathrm{Co}^{0}$ species are likely to be found primarily on top of Co clusters, available for interaction with ethanol. When exposing the $\mathrm{Co} / \mathrm{CeO} \mathrm{O}_{2}(111)$ model catalyst to 0.1 mbar of ethanol, $\mathrm{Co}^{2+}$ species decreased drastically with increasing temperature, and Co was mostly metallic at $600 \mathrm{~K}$. This process was accompanied by further reduction of ceria and the formation of surface carbon deposits, which was not observed on pure ceria and contributed to the severe intensity loss in the Co $2 p$ spectra, together with Co nanoparticles sintering.

Different cobalt-based catalyst configurations were reported by Turczyniak and co-workers [152], who investigated the effect of SRE conditions over various forms of Co (single crystal, nanoparticles, and supported on $\mathrm{CeO}_{2}$ and $\mathrm{ZnO}$ ) by means of ambient pressure XP and absorption spectroscopies. Systems were exposed to oxidising, reducing and SRE atmospheres, and results showed that under $0.2 \mathrm{mbar}_{2}$ at $523 \mathrm{~K}$, Co $2 \mathrm{p}_{3 / 2}$ signal and the $\mathrm{Co}_{3}$-edge spectra were characteristic for the $\mathrm{Co}_{3} \mathrm{O}_{4}$ spinel oxide for each cobalt configuration, while $\mathrm{Ce} 3 \mathrm{~d} \mathrm{XP}$ spectra exhibited typical features for bulk $\mathrm{CeO}_{2}$. Nevertheless, under 0.2 mbar $\mathrm{H}_{2}$ at $693 \mathrm{~K}$, ceria-supported $\mathrm{Co}_{3} \mathrm{O}_{4}$ was not entirely reduced to metallic Co compared to the single crystal (Co-sc) and the nanopowdered sample, but in fact a significant amount of unreduced $\mathrm{CoO}$ remained on the surface. As expected, ceria partially reduced under $\mathrm{H}_{2}$ environment, but it is worth noting that $\mathrm{Co}$ presence promoted the reduction of the ceria support, as compared to pure ceria. Interestingly, a gaseous mixture of ethanol and $\mathrm{H}_{2} \mathrm{O}\left(\mathrm{C}_{2} \mathrm{H}_{5} \mathrm{OH}: \mathrm{H}_{2} \mathrm{O}\right.$ ratio of 1:3) caused a higher reducing effect for cobalt oxides than molecular $\mathrm{H}_{2}$, since supported Co got fully reduced to the metallic state under 0.3 mbar SRE conditions. Thus, the milder reduction conditions for Co-sc and Co nanoparticles suggested that the ceria support had a stabilization effect over supported $\mathrm{CoO}$. As for the $\mathrm{CeO}_{2}$ support, both NAP-XPS and NEXAFS results indicated slight oxidation of the oxide. Apart from the features related to the contribution of gaseous $\mathrm{H}_{2} \mathrm{O}$ and $\mathrm{C}_{2} \mathrm{H}_{5} \mathrm{OH}, \mathrm{O}$ 1s spectra of the systems under SRE showed additional components: the band at $531.5 \mathrm{eV}$ was attributed to adsorbed -OH groups, whereas the peak located at 533.4 was correlated with molecularly adsorbed $\mathrm{H}_{2} \mathrm{O}$ species and/or oxygenated carbon impurities. Finally, an asymmetric peak at $284.4 \mathrm{eV}$ prevailed in all $\mathrm{C} 1 \mathrm{~s}$ $\mathrm{XP}$ spectra, characteristic of hydrocarbon or graphitic carbon species. However, a severe difference in the amount of deposited $C$ under SRE conditions was detected between unsupported and supported cobalt-based samples, revealing the role of mobile ceria lattice oxygen atoms in the prevention of catalyst coking. Following their work, Turczyniak et al. examined the impact of the $\mathrm{Co} / \mathrm{CeO}_{2}$ catalyst composition and surface oxidation state on the SRE reaction performance by combining operando and ex situ XPS in a wide pressure range $\left(0.2-20\right.$ mbar) [151]. The catalyst was subjected to oxidative $\left(\mathrm{O}_{2}\right)$ or reductive $\left(\mathrm{H}_{2}\right.$ or ethanol vapour) gaseous environments before exposing it to SRE conditions. Under $0.2 \mathrm{mbar}$ $\mathrm{O}_{2}$ and $523 \mathrm{~K}, \mathrm{Co} 2 \mathrm{p}$ and $\mathrm{Ce} 3 \mathrm{~d}$ signals indicated the presence of $\mathrm{Co}_{3} \mathrm{O}_{4}$ spinel phase and bulk $\mathrm{CeO}_{2}$, respectively. Contrarily, reducing pretreatment conditions $\left(0.2 \mathrm{mbar} \mathrm{H}_{2}\right.$ or gaseous ethanol at $\left.693 \mathrm{~K}\right)$ induced the complete reduction of $\mathrm{Co}$ to the metallic state and a partial reduction of ceria, leading to a mixture of $\mathrm{Ce}^{3+}$ and $\mathrm{Ce}^{4+}$ species with a higher $\mathrm{Ce}^{3+} / \mathrm{Ce}^{4+}$ ratio under ethanol atmosphere than under hydrogen. Independent of the prior surface oxidation state under the pretreatment atmospheres, metallic $\mathrm{Co}^{0}$ bands dominated the $\mathrm{Co} 2 \mathrm{p}_{3 / 2}$ photoemission spectrum during SRE conditions (EtOH: $\mathrm{H}_{2} \mathrm{O}=1: 3$ at $693 \mathrm{~K}$ ), while the mixture of $\mathrm{Ce}^{3+}$ and $\mathrm{Ce}^{4+}$ species present under reaction conditions was influenced by the pretreatment, as indicated by the small but notable differences in the $\mathrm{Ce} 3 \mathrm{~d}$ spectra. $\mathrm{CO}$ and $\mathrm{H}_{2}$ production were favoured with this surface state, indicating that $\mathrm{C}-\mathrm{C}$ bond scission is the key route in this pressure regime. The population of adsorbed hydroxyl groups increased with the degree of ceria reduction, but they surprisingly inhibited the SRE activity and the $\mathrm{C}-\mathrm{C}$ bond yield. Therefore, oxidised ceria supports promoted the cleavage of $\mathrm{C}-\mathrm{C}$ ethanol bond with $\mathrm{Co}$ keeping its metallic state.

Another example of a cobalt-based catalyst for SRE reaction is reported in the work of Sohn et al. [153], who investigated the effect of supported cobalt nanoparticles on the catalytic performance of nano-ceria $\left(\mathrm{CeO}_{2}-\mathrm{NP}\right)$ and micro-ceria $\left(\mathrm{CeO}_{2}-\mathrm{MP}\right)$ under ethanol steam reforming conditions, by using NAP-XPS and X-ray absorption near edge structure (XANES) techniques. Those characterization methods allowed the study of both surface and bulk properties of the samples, respectively. $\mathrm{CeO}_{2}-\mathrm{NP}$ size varied from 
2 to $10 \mathrm{~nm}$, with an average size of $4 \mathrm{~nm}$, while $\mathrm{CeO}_{2}-\mathrm{MP}$ exhibited much larger particle sizes, which varied significantly from 40 to $200 \mathrm{~nm}$ with a mean particle size of $120 \mathrm{~nm}$. Cobalt particle sizes were also different between the two $\mathrm{Co} / \mathrm{CeO}_{2}$ samples, with bigger $\mathrm{Co}$ particles observed over $\mathrm{CeO}_{2}-\mathrm{MP}$. Researchers found that surface reducibility was altered by the particle size of bare ceria particles, smaller ones leading to a higher surface reduction degree. The presence of completely oxidised Co nanoparticles on $\mathrm{CeO}_{2}-\mathrm{NP}$ and $\mathrm{CeO}_{2}-\mathrm{MP}$ hindered surface reducibility of ceria. This effect could be explained since reducing agents (such as ethanol and produced hydrogen) may be principally consumed to reduce the cobalt oxide species $\left(\mathrm{Co}_{3} \mathrm{O}_{4}\right.$ and $\left.\mathrm{CoO}\right)$, which are fully oxidised at the initial steps $(\mathrm{He}, 300 \mathrm{~K})$. It could also be caused by the dissociation of $\mathrm{H}_{2} \mathrm{O}$ molecules on the $\mathrm{Co}$ surface, which may spillover to the ceria support and subsequently partially oxidise its surface. Under SRE conditions and increasing temperature (623-723 K with 0.13 and 1.33 mbar of $\mathrm{C}_{2} \mathrm{H}_{5} \mathrm{OH}$ and $\mathrm{H}_{2} \mathrm{O}$, respectively, so as to achieve an ethanol and water mixture of 1:10 molar ratio), researchers observed an increasing degree of ceria reduction. NAP-XPS measurements indicated the presence of both metallic $\mathrm{Co}$ and $\mathrm{CoO}_{x}$ at the surface of cobalt nanoparticles, which actually consisted of a metallic Co-based shell and $\mathrm{CoO}_{\mathrm{x}}$-based core. Eventually, they found much larger differences between $\mathrm{Co} / \mathrm{CeO}_{2}-\mathrm{NP}$ and $\mathrm{Co} / \mathrm{CeO}_{2}-\mathrm{MP}$ than between bare ceria supports, which reflected the importance of metallic Co in SRE catalysis. In another work, Sohn et al. [101] examined the same catalysts (Co loaded $\mathrm{CeO}_{2}-\mathrm{NP}$ and MP) and the focus of their study was the surface oxygen mobility and oxygen vacancy formation on their samples, which has been already reviewed in Section 3.1.

$\mathrm{Ni}$-oxide based materials have also emerged as promising catalysts for the SRE reaction owing to their ability to activate $\mathrm{C}-\mathrm{C}$ and $\mathrm{C}-\mathrm{H}$ bonds in hydrocarbon oxygenates [280] and their activity comparable to that of expensive noble metals such as $\mathrm{Rh}, \mathrm{Pt}$ and $\mathrm{Pd}[269,271]$. The combination of $\mathrm{Ni}$ and ceria in a catalyst confers the ability to activate both ethanol ( $\mathrm{C}-\mathrm{C}$ and $\mathrm{C}-\mathrm{H}$ bonds) and $\mathrm{H}_{2} \mathrm{O}(\mathrm{O}-\mathrm{H})$, and selectively extract hydrogen avoiding the production of $\mathrm{CH}_{4}$ or other $\mathrm{C}-\mathrm{O}$ by-products (aldehydes or olefins). Liu and colleagues [154] combined NAP-XPS and AP-IRRAS techniques to elucidate the catalytic chemistry (active phases and surface species) and the elementary steps related to the SRE reaction over $\mathrm{Ni} / \mathrm{CeO}_{2}(111)$ model catalysts. Ceria was evaporated onto a Ru single crystal (0001) and was estimated to be ca. $4 \mathrm{~nm}$ thick. Ni was then deposited on the as-prepared ceria film by physical evaporation, and its coverage was estimated to be $0.15 \mathrm{ML}$. Although ceria alone is not catalytically active for the SRE process, researchers studied the chemistry of ethanol and $\mathrm{H}_{2} \mathrm{O}$ at elevated pressures over bare $\mathrm{CeO}_{2}(111)$ before investigating the $\mathrm{SRE}$ reaction over $\mathrm{Ni} / \mathrm{CeO}_{2}(111)$ catalyst. The exposure of $\sim 0.05$ mbar of ethanol at $300 \mathrm{~K}$ led to the formation of ethoxy species $\left(\mathrm{CH}_{3} \mathrm{CH}_{2} \mathrm{O}-\right)$ on the ceria surface, as reflected in both $\mathrm{C} 1 \mathrm{~s}$ and $\mathrm{O} 1 \mathrm{~s}$ regions, formed upon binding of deprotonated $\mathrm{H}$ to ceria lattice oxygen due to the dissociative adsorption of ethanol. After adding $\sim 0.26 \mathrm{mbar}$ of water into the reaction to achieve $\mathrm{a} \sim 5: 1\left(\mathrm{H}_{2} \mathrm{O}: \mathrm{EtOH}\right)$ vapour mixture, an additional band appeared in the $\mathrm{C}$ 1 s region, indicating the formation of small amounts of dioxyethylene species $\left(\mathrm{CH}_{3} \mathrm{CHO}_{2}-\right)$. In this atmosphere, the sample was then heated from 300 to $700 \mathrm{~K}$ and, according to the recorded $\mathrm{C} 1 \mathrm{~s}$ and $\mathrm{O}$ $1 \mathrm{~s}$ spectra, most of the ethoxy species recombined with surface hydroxyls and gradually desorbed from the surface up to $700 \mathrm{~K}$. Two additional features appeared, attributed to dioxyethylene $\left(\mathrm{CH}_{3} \mathrm{CHO}_{2}-\right)$ and acetate $\left(\mathrm{C}_{2} \mathrm{H}_{3} \mathrm{OO}-\right)$ species, generated through the oxidation of ethoxy species, but no evidence of $\mathrm{C}-\mathrm{C}$ bond scission was observed. As expected, bare ceria is not likely to perform the key step of the SRE reaction. Nevertheless, ceria strongly became reduced by ethanol from 500 to $700 \mathrm{~K}$ generating $\mathrm{Ce}^{3+}$ species, as well as oxygen vacancies, which in turn dissociated $\mathrm{H}_{2} \mathrm{O}$ into hydroxyl groups and even led to the formation of cerium hydroxide compounds. The same experimental procedure was followed for the $\mathrm{Ni} / \mathrm{CeO}_{2}(111)$ catalyst, and NAP-XPS results (see Figure 7) revealed that under SRE conditions small supported $\mathrm{Ni}$ nanoparticles were present as $\mathrm{Ni}^{0} / \mathrm{Ni}_{\mathrm{x}} \mathrm{C}$, the active phase that leads to both $\mathrm{C}-\mathrm{C}$ and $\mathrm{C}-\mathrm{H}$ scission of ethanol and also carbon accumulation. Concurrently, the ceria surface appeared highly reduced and hydroxylated and played an important role in the deprotonation of ethanol and water with subsequent generation of hydroxyls, which are essential intermediates to react 
and remove $\mathrm{CH}_{x}$ or surface carbon. Indeed, the active phase of $\mathrm{CeO}_{x}$ was a $\mathrm{Ce}^{3+}(\mathrm{OH})_{x}$ compound resulted from the reduction by ethanol and the efficient dissociation of $\mathrm{H}_{2} \mathrm{O}$.


Figure 7. (a) $\mathrm{Ce} 4 \mathrm{~d}$ and (b) $\mathrm{Ni} 3 \mathrm{p}$ spectra of $\mathrm{Ni} / \mathrm{CeO}_{2}(111)$ surface under SRE conditions, and (c) surface $\mathrm{Ce}^{3+}$ concentration comparison between $\mathrm{CeO}_{2}(111)$ and $\mathrm{Ni} / \mathrm{CeO}_{2}(111)$ catalysts. Reprinted with permission from [154], copyright 2016, Royal Society of Chemistry.

Despite the multiple advantages of bio-derived ethanol, as its low sulphur content and low toxicity as compared to methanol, steam reforming of methanol (SRM) has a lower activation temperature and better selectivity (less $\mathrm{CO}$ or coke formation) than other heavier alcohols owing to the absence of a $\mathrm{C}-\mathrm{C}$ bond [286]. The most common studied catalysts for SRM are Cu-based metal-oxides because of copper's well-known capability of catalysing methanol synthesis in the industry [287-289]. Nevertheless, Cu-based catalysts possess multiple drawbacks such as their pyrophoricity and catalytic deactivation due to metal sintering. Nickel has recently been reported as a non-expensive alternative metal with favourable catalytic activity and selectivity for the SRM reaction [290,291]. In spite of being prone to deactivation due to the coke formation, Liu et al. showed that the combination of $\mathrm{Ni}$ with $\mathrm{Ce}$ is able to significantly mitigate the accumulation of surface carbon. [154]. For this reason, they recently investigated both powder $\left(\mathrm{Ni} / \mathrm{CeO}_{2}\right)$ and model $\left(\mathrm{Ni} / \mathrm{CeO}_{2}(111)\right)$ catalysts for SRM reaction in order to elucidate structure-reactivity correlations under reaction conditions [155]. In situ XRD and DRIFTS were used to study the active phase evolution and surface species transformation on powder catalysts, and they observed phase transitions of $\mathrm{NiO} \rightarrow$ $\mathrm{NiC} \rightarrow \mathrm{Ni}$ and $\mathrm{CeO}_{2} \rightarrow \mathrm{CeO}_{2-x}$ during the reaction. By means of NAP-XPS, researchers first examined the interaction of methanol with an oxidised $\mathrm{Ni} / \mathrm{CeO}_{2}(111)$ surface in the temperature range of $300-700 \mathrm{~K}$. The formation of methoxy and hydroxyls groups at room temperature, as a result of dissociative adsorption of methanol, was detected through both $\mathrm{O} 1 \mathrm{~s}$ and $\mathrm{C} 1 \mathrm{~s}$ spectra. However, these contributions disappeared upon heating the surface up to $700 \mathrm{~K}$, likely due to methanol desorption. With a moderate dose of methanol ( $2 \mathrm{~L}, \mathrm{~L}=$ Langmuir), no Ni reduction was detected and only a minor reduction of ceria was observed. These results indicated that a fully oxidised $\mathrm{Ni} / \mathrm{CeO}_{2}(111)$ surface is catalytically inert for methanol reaction. The same measurements were performed over a reduced $\mathrm{Ni} / \mathrm{CeO}_{1.8}(111)$ surface, which was found to behave differently. $\mathrm{O} 1 \mathrm{~s}$ spectra showed an enhancement in the relative intensity of hydroxyl/methoxy peak $\left(-\mathrm{OH} / \mathrm{CH}_{3} \mathrm{O}-\right)$ at $300 \mathrm{~K}$, resulting from the higher amount of oxygen vacancies on the oxide substrate for dissociative adsorption of methanol, but again it attenuated and finally disappeared as temperature increased to $700 \mathrm{~K}$. Nevertheless, at $500 \mathrm{~K}$ they detected a new contribution, which was attributed to a Ni carbide $\left(\mathrm{Ni}_{3} \mathrm{C}\right)$ species. Finally, another experiment was performed by heating the pre-dosed methoxy covered surface in a background of $2.66 \times 10^{-5}$ bar of water, so as to check the effect of surface hydroxyl and $\mathrm{H}_{2} \mathrm{O}$. Similarly, surface $\mathrm{C} / \mathrm{Ni}_{3} \mathrm{C}$ species were formed at $500 \mathrm{~K}$, but no carbon was detected on the surface upon heating to $700 \mathrm{~K}$, fact that emphasized the significance of hydroxyls/water on the selectivity of SRM 
and the role of metal-support interactions, that links the metal and the oxide to complete the reaction cycle and contributes to the high selectivity of the catalysts.

\section{Methanol Oxidation}

The oxidation of methanol has been proposed as a probe reaction to characterise the catalytic performance of metal oxides [292]. Depending on the products generated, catalysts have been classified as acidic, basic or redox. Acidic materials yield coupling products such as dimethyl ether, basic materials cause dehydrogenation with $\mathrm{CO}$ and $\mathrm{CO}_{2}$ as products, and redox catalysts produce formaldehyde. Very recently, Mullins [156] reported the reaction of methanol with and without $\mathrm{O}_{2}$ on a flat and highly crystalline $\mathrm{CeO}_{2}(100)$ surface as a function of temperature and pressure, via ambient pressure XPS. The results indicated that, in the absence of $\mathrm{O}_{2}$, methoxy $\left(\mathrm{CH}_{3} \mathrm{O}-\right)$ is the prevailing surface species in both low-pressure $\left(\leq 1.3 \times 10^{-5} \mathrm{mbar}\right)$ and high-pressure regimes ( $\left.\geq 0.13 \mathrm{mbar}\right)$. Moreover, methanol decomposition considerably reduced the ceria thin film and $C_{x}$ accumulated on its surface. Upon dosing oxygen, $C_{x}$ surface depositions were not observed, and the nature of the dominant surface species was dependent on the pressure. Methoxy still prevailed in the low-pressure regime, and its coverage decreased with temperature and was smaller than the coverage in the absence of $\mathrm{O}_{2}$, which evidences the reaction between methoxy groups and the gaseous oxygen. In the high-pressure regime, surface formate $(\mathrm{HCOO})^{-}$dominated. Therefore, the nature of surface species appeared to be related to the oxygen ability to maintain a completely oxidised ceria surface during the methanol reaction.

\subsubsection{Hydrogenation Reactions}

Recently, ceria has received intense interest in reactions such as hydrogenation of alkynes to alkenes $[293,294]$. Indeed, the interactions of $\mathrm{H}_{2}$ with $\mathrm{CeO}_{2}$ have long been experimentally and theoretically studied to understand the redox properties of ceria-based catalysts, as ceria oxygen vacancies are commonly formed through hydrogen reduction $[295,296]$. Nevertheless, there is still no direct experimental evidence for the presence of cerium hydride $(\mathrm{Ce}-\mathrm{H})$ upon hydrogen dissociation over ceria, and the mechanism of the hydrogenation reaction still remains elusive. In their work, Wu et al. [157] reported for the first time direct experimental evidence for the formation of both surface and bulk $\mathrm{Ce}-\mathrm{H}$ species upon $\mathrm{H}_{2}$ interaction with ceria nanorods by using in situ inelastic neutron scattering spectroscopy (INS). Combined with other in situ spectroscopic techniques such as IR, Raman and NAP-XPS, as well as DFT calculations, their results confirmed that hydrogen dissociates over ceria creating homolytic products $(\mathrm{OHs})$ on a close-to-stoichiometric ceria surface, while heterolytic products $(\mathrm{Ce}-\mathrm{H}$ and $\mathrm{OH})$ result with the presence of induced oxygen vacancies in the oxide surface. NAP-XPS measurements were performed over ceria nanorods during an $\mathrm{H}_{2}$ treatment $(0.65 \mathrm{mbar})$ at different temperatures $(533,623$ and $673 \mathrm{~K}$ ) in order to monitor ceria oxidation states upon hydrogen interaction. Another investigation of ceria's hydrogenation ability, specifically $\mathrm{C}=\mathrm{O}$ bond hydrogenation, was carried out on a series of $\mathrm{CeO}_{2} / \mathrm{Pt}$ catalysts by Mueanngern and co-workers [158]. The goal of their work was to examine the scaling of catalytic activity for a support-mediated reaction pathway with respect to distance from the active metal-support interface. With this aim, researchers prepared an inverse catalyst system based on $\mathrm{CeO}_{2}$ nanocubes supported on a $\mathrm{Pt}$ thin film. Langmuir-Blodgett deposition was employed to deposit the ceria nanocubes at well-controlled coverages onto the metallic film, and surface pressure was followed as a function of film compression during nanoparticle deposition. They showed that deposition of $\mathrm{CeO}_{2}$ nanoparticles leads to two types of $\mathrm{Pt} / \mathrm{CeO}_{2}$ interfaces that extend over multiple length scales: firstly, a nanoscale interface defined by the contact of individual ceria nanoparticles with the Pt surface and, secondly, a larger, mesoscale interface defined by the limit between domains of self-assembled nanoparticles and the surrounding $\mathrm{Pt}$ support. Results indicated that almost no $\mathrm{C}=\mathrm{O}$ bond hydrogenation occurred within a domain of closely spaced ceria nanoparticles. Instead, the rate of $\mathrm{C}=\mathrm{O}$ bond hydrogenation was quite high at the boundary between a domain of ceria nanoparticles and the surrounding $\mathrm{Pt}$ substrate. Three different catalysts with $\mathrm{CeO}_{2}$ nanoparticles at 450,150 and $75 \mathrm{~cm}^{2}$ compression areas were analysed by 
means of NAP-XPS under approximately $0.4 \mathrm{mbar}_{2}$ and a temperature range of 300-473 K, and measurements confirmed that the observed kinetics are not caused by variations in the ceria oxidation state due to $\mathrm{H}$ spillover or $\mathrm{Pt}$ decoration by the migration of reduced $\mathrm{Ce}$ atoms during reaction. Alternatively, they assumed that reaction kinetics were rate-limited by the surface displacement of crotyl-oxy intermediates as they form on ceria nanoparticles and consequently diffuse and react on Pt.

\subsection{Gas-Solid Electrocatalysis}

Nowadays, research and development of electrochemical devices such as batteries, fuel cells and supercapacitors have surged due to the demand for clean, secure and sustainable energy sources. Solid oxide electrochemical cells (SOCs) are among the most promising technologies for efficient fuel generation and electric power production. SOCs are a general class of solid-state electrochemical devices that comprise solid oxide fuel cells (SOFCs), which convert fuels and oxygen to electric power, and solid oxide electrolysis cells (SOECs) for fuel generation from electricity. Although SOCs have enormous potential for future mass $\mathrm{H}_{2}$ production [297] and offer several attractive advantages, including high efficiency and tolerance to catalyst poisoning, reformation of hydrocarbon fuels and the possibility of burning hydrocarbon fuels directly, these devices have not yet found extensive use in quotidian applications [298]. The understanding of fundamental processes in the bulk and at the interfaces of electrochemical devices is decisive in order to develop new technologies with improved efficiency and performance.

Common electrochemical evaluations of electrode overpotential usually employ voltammetry and electrochemical impedance spectroscopy. Nevertheless, there is still a lack of direct knowledge regarding the surface chemistry and electrochemical processes that guide these systems, owing to the inherently convoluted nature of electrochemical processes and the need for suitable in situ techniques that explore these issues at relevant pressures and temperatures. Surface analytical techniques such as atomic force microscopy (AFM), scanning tunnelling microscopy (STM) and conventional UHV XPS cannot be used due to the gaseous reactant environment, high operating temperatures ( $>873 \mathrm{~K}$ ) and far-from-equilibrium conditions related with the operating devices. For this reason, new in situ and operando tools are being developed and already began to provide fundamental insight into SOC processes. Among them, NAP-XPS allows the resolution of local surface potentials, electrochemically active regions and shifts in surface oxidation states in operating SOCs [299-302].

Solid oxide electrochemical cells are complex devices composed of three basic components: a porous anode, an electrolyte membrane and a porous cathode. Figure 8 shows a schematic representation of the most common design of an electrolyte supported SOFC [303], in which the dense electrolyte membrane supports both electrodes. The materials typically employed in SOECs are basically similar to those used for SOFCs [304-306]. The electrolyte, usually a dense oxide-ion conductor such as yttria-stabilized zirconia (YSZ), electronically isolates the air and fuel compartments and enhances pure oxygen ion transport between the anode and the cathode. Other materials, including scandia-stabilized zirconia (ScSZ), ceria-based electrolytes (fluorite structure) or the lanthanum gallate (LSGM, perovskite structure) are also considered [298], but the high temperatures (>923 K) required to transport oxide through the solid-state electrolyte restrict the materials that can be used as SOC components [307]. Electrodes must combine oxide-ion conduction with catalytically active electronically conducting materials, that is, exhibit mixed ionic-electronic conductivity (MIEC). For this reason, the most commonly used MIEC material for the cathode (which catalyses the oxidation of fuel in electrolysis mode) is a metal-oxide composite composed of YSZ and metallic nickel (Ni/YSZ), but alternative materials include samaria doped ceria (SDC) with dispersed Ni nanoparticles, titanate/ceria composites or the perovskite material lanthanum strontium chromium manganite (LSCM). As for the anode, lanthanum strontium manganite (LSM)/YSZ composite is the most habitually used material to date, although different materials have also been proposed.

Doped cerium oxide, $\mathrm{Ce}_{1-\mathrm{x}} \mathrm{M}_{\mathrm{x}} \mathrm{O}_{2-\delta}$ (M: rare-earth or alkaline-earth cations), has received considerable interest for potential use in SOCs because of its higher ionic conductivity with respect to yttria-stabilized 
zirconia and a lower cost compared with lanthanum gallate-based phases. Solid electrolytes based on doped ceria materials allow a decrease in the SOFC operation temperature due to its high oxide ion conduction, which consequently simplifies various technological issues. SOFC anode can also be based on doped ceria materials, and $\mathrm{Ce}_{1-\mathrm{x}} \mathrm{M}_{\mathrm{x}} \mathrm{O}_{2-\delta}$ solid solutions (where $\mathrm{M}=\mathrm{Gd}$ or Sm, and $\mathrm{x}=0.10-0.20$ ) exhibit the highest level of oxide ion conductivity among ceria-based ionic conductors [80,308]. Nevertheless, relatively few studies have used doped ceria materials as solid electrolyte under electrolysis mode, likely due to the partial reduction of $\mathrm{Ce}^{4+}$ to $\mathrm{Ce}^{3+}$ under operation caused by the high voltages applied, which results in electronic conduction and thus a short-circuit of the cell [298].
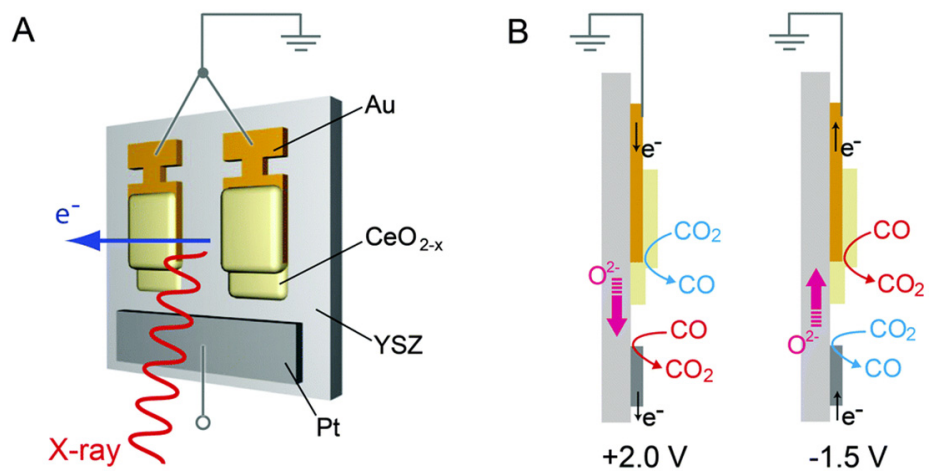

Figure 8. (A) Schematic setup of an electrochemical cell comprising a $300 \mathrm{~nm}$ Pt counter electrode (CE), a $300 \mathrm{~nm} \mathrm{Au} \mathrm{current} \mathrm{collector} \mathrm{on} \mathrm{top} \mathrm{of} \mathrm{a} 50 \mathrm{~nm}$ alumina film (not shown) and a 350 or $1000 \mathrm{~nm}$ ceria working electrode (WE) patterned onto a polycrystalline yttria-stabilized zirconia (YSZ) substrate. (B) Schematic illustration of electrochemical reactions under positive and negative biases. Reprinted with permission from [303], copyright 2014, Royal Society of Chemistry.

Thus, in this third and last block we have gathered all reported gas-solid electrocatalytic reactions examined with the NAP-XPS technique, based on both SOFC and SOEC systems with cerium oxide as a component. Four different types of electrocatalytic reactions performed through these systems are found in literature, and Table 2 provides the list of the reports published so far.

Table 2. Published NAP-XPS investigations of ceria-based catalysts in electrocatalytic reactions.

\begin{tabular}{|c|c|c|c|c|c|c|}
\hline Reaction & Catalyst & $P_{\max }$ (mbar) & $\mathrm{T}(\mathrm{K})$ & X-ray Source & Year & Ref. \\
\hline \multirow{10}{*}{$\begin{array}{l}\mathrm{H}_{2} \mathrm{O} \text { electrolysis/ } \\
\mathrm{H}_{2} \text { electro-oxidation }\end{array}$} & $\begin{array}{l}\mathrm{WE}=\mathrm{CeO}_{2-\mathrm{x}} \\
\mathrm{CE}=\mathrm{Pt}\end{array}$ & 0.66 & 973 & Synchrotron & 2009 & [75] \\
\hline & $\begin{array}{l}\mathrm{WE}=\mathrm{CeO}_{2-\mathrm{x}} \\
\mathrm{CE}=\mathrm{Pt}\end{array}$ & 1.06 & 923-1013 & Synchrotron & 2010 & [300] \\
\hline & $\begin{array}{l}\mathrm{WE}=\mathrm{CeO}_{2-x} \\
\mathrm{CE}=\mathrm{Pt}\end{array}$ & 1 & 1023 & Synchrotron & 2010 & [309] \\
\hline & $\begin{array}{l}\mathrm{WE}=\mathrm{CeO}_{2} \\
\mathrm{CE}=\mathrm{Pt}\end{array}$ & 0.65 & 973-1023 & Synchrotron & 2012 & [310] \\
\hline & $\mathrm{SDC}^{\mathrm{a}}$ & 1.06 & 739-923 & Synchrotron & 2012 & [311] \\
\hline & $\begin{array}{l}\mathrm{WE}=\mathrm{CeO}_{2-x} \\
\mathrm{CE}=\mathrm{Pt}\end{array}$ & 0.65 & 973 & Synchrotron & 2013 & [312] \\
\hline & $\begin{array}{l}\mathrm{CeO}_{2-x} \text { and } \\
\mathrm{SDC}^{-}\end{array}$ & 0.37 & 763-923 & Synchrotron & 2016 & [313] \\
\hline & $\mathrm{Ni} / \mathrm{GDC}^{\mathrm{b}}$ & 0.2 & 773-973 & Synchrotron & 2017 & [314] \\
\hline & $\begin{array}{l}\mathrm{WE}=\mathrm{NiO} / \mathrm{GDC} \\
\mathrm{CE}=\mathrm{Pt}\end{array}$ & 0.2 & 973 & Synchrotron & 2017 & [315] \\
\hline & $\begin{array}{l}\mathrm{WE}=\mathrm{Ni} / \mathrm{GDC} \\
\mathrm{CE}=\mathrm{LSC}^{\mathrm{c}}\end{array}$ & 0.1 & 923 & Synchrotron & 2018 & [316] \\
\hline
\end{tabular}


Table 2. Cont.

\begin{tabular}{lllllll}
\hline Reaction & Catalyst & $\mathbf{P}_{\max }(\mathbf{m b a r})$ & $\mathbf{T}(\mathbf{K})$ & X-ray Source & Year & Ref. \\
\hline \multirow{2}{\mathrm{CO}_{2}\text{electrolysis/}}{$\begin{array}{l}\mathrm{WE}=\mathrm{CeO}_{2-\mathrm{x}} \\
\mathrm{CO} \text { electro-oxidation }\end{array}$} & $\begin{array}{l}\mathrm{CE}=\mathrm{Pt} \\
\mathrm{WE}=\mathrm{Ni} / \mathrm{GDC}\end{array}$ & 0.53 & 873 & Synchrotron & 2014 & {$[303]$} \\
& $\mathrm{CE}=\mathrm{Pt}$ & 893 & Synchrotron & 2015 & {$[317]$} \\
\hline $\mathrm{CH}_{4}$ electro-oxidation & $\begin{array}{l}\mathrm{WE}=\mathrm{Ni} / \mathrm{GDC} \\
\mathrm{CE}=\mathrm{Pt}\end{array}$ & 0.1 & 973 & Synchrotron & 2013 & {$[318]$} \\
\hline
\end{tabular}

$\mathrm{WE}=$ working electrode, $\mathrm{CE}=$ counter electrode; ${ }^{\mathrm{a}} \mathrm{SDC}=\mathrm{Sm}_{0.2} \mathrm{Ce}_{0.8} \mathrm{O}_{1.9-\delta} ;{ }^{\mathrm{b}} \mathrm{GDC}=\mathrm{Gd}_{0.1} \mathrm{Ce}_{0.9} \mathrm{O}_{2} ;{ }^{\mathrm{c}} \mathrm{LSC}=$ $\mathrm{La}_{0.6} \mathrm{Sr}_{0.4} \mathrm{CoO}_{3-\delta}$.

\subsection{1. $\mathrm{H}_{2} \mathrm{O}$ Electrolysis/ $\mathrm{H}_{2}$ Electro-Oxidation}

The first experiments performed with NAP-XPS in order to probe oxidation states of all exposed surfaces and local electric potentials of ceria thin film electrodes operating in SOCs are associated to DeCaluwe and co-workers [75]. The SOC cell design consisted on a $300 \mathrm{~nm}$ thick $\mathrm{CeO}_{2-\mathrm{x}}$ thin film with a patterned Au current collector as working electrode (WE) and a porous Pt counter electrode (CE), both supported on the same side of a $1 \mathrm{~mm}$ thick single-crystal YSZ electrolyte to enable NAP-XPS to access the electrode-electrolyte interfaces. XPS measurements were performed during electrochemical oxidation of $\mathrm{H}_{2}$ and electrolysis of $\mathrm{H}_{2} \mathrm{O}$ (see Equations (8) and (9), respectively) at $973 \mathrm{~K}$, and results showed the extent of near-surface $\mathrm{Ce}^{4+}$ reduction to $\mathrm{Ce}^{3+}$ upon increasing cell voltage. Large negative biases caused an increase of $\mathrm{Ce}^{4+}$ species with respect to equilibrium values, as well as a resistance drop due to $\mathrm{H}_{2}$ oxidation activity. Contrarily, the application of positive voltages drove $\mathrm{H}_{2} \mathrm{O}$ electrolysis on ceria and a further increase of $\mathrm{Ce}^{3+}$ species. Similar findings were reported by DeCaluwe et al. [300] in another study of the same SOC cell geometry. Additional tests indicated that highly reduced ceria surface, caused by an increased $\mathrm{H}_{2}-$ to- $\mathrm{H}_{2} \mathrm{O}$ ratio, was more active for electrolysis.

$$
\begin{aligned}
& \mathrm{H}_{2}+\mathrm{O}_{2} \rightarrow \mathrm{H}_{2} \mathrm{O}+2 \mathrm{e}^{-}, \\
& \mathrm{H}_{2} \mathrm{O}+2 \mathrm{e}^{-} \rightarrow \mathrm{H}_{2}+\mathrm{O}^{2-},
\end{aligned}
$$

Further studies of the same SOC system (with variable ceria electrode thickness) were performed by Zhang and researchers [309,310,312] by using NAP-XPS, among other characterization tools. Operando spectroscopic analyses, carried out under a $\sim 1$ mbar pressure gaseous mixture of $\mathrm{H}_{2}$ and $\mathrm{H}_{2} \mathrm{O}$ (1:1) and at temperatures above $973 \mathrm{~K}$, allowed the measurement of local surface ceria oxidation states and the detection of electrochemically active regions of ceria thin films. Results revealed that the electrochemically active regions extend 150-200 $\mu \mathrm{m}$ away from the current collectors on ceria electrodes, and the persistence of the $\mathrm{Ce}^{3+} / \mathrm{Ce}^{4+}$ shifts in these regions suggested that the surface reaction kinetics and lateral electron transport on the ceria electrodes are co-limiting processes. Using a different experimental setup, Chueh and co-workers [311,313] combined ambient pressure XPS and electrochemical impedance spectroscopy to simultaneously quantify the concentration of active $\mathrm{Ce}^{3+}$ species on the surface and in the bulk of a Sm-doped $\mathrm{CeO}_{2}(111)$ film under catalytically relevant temperatures and $\mathrm{H}_{2}-\mathrm{H}_{2} \mathrm{O}$ gas mixtures. On both works, $\mathrm{SDC}$ thin films were grown on YSZ single crystal substrates and interdigitated Pt electrical contacts were deposited and patterned on top of the thin films. The results revealed a highly reduced and stable surface even under relatively oxidising conditions, whereas the bulk doped ceria was almost entirely $\mathrm{Ce}^{4+}$. Measurements of the chemical potential of surface oxygen indicated a large deviation from the bulk values, and this entropic difference played a key role in surface $\mathrm{Ce}^{3+}$ stabilization. Upon comparing the surface chemical capacitance of $\mathrm{CeO}_{2-x}$ and SDC, researchers found that $\mathrm{Sm}$ leads to a slight decrease of surface $\mathrm{Ce}^{3+}$ concentration, but a 10-fold increase of the surface capacitance. Therefore, cation substitution represents an approach to tune the surface capacitance of MIECs. Finally, Papaefthimiou et al. investigated the surface 
composition and oxidation state of a Ni/GDC electrode in a SOEC cell during water electrolysis by means of ambient pressure XPS and NEXAFS spectroscopies [315]. Papaefthimiou and colleagues [314] had previously reported on the effect of a steam environment on the oxidation state and composition of $\mathrm{Ni} / \mathrm{GDC}$ cermets and found that, in the mbar pressure regime and at intermediate temperature conditions, water acted as an oxidant for Ni but had a dual oxidant/reducing function for doped ceria. In their succeeding work, they showed that the oxidation state and composition of the electrode during steam electrolysis are dynamic and determined by a complex interplay between the thermo-chemical oxidation caused by water vapour and the electrochemical reduction of $\mathrm{Ni}$.

Finally, Nurk et al. [316] monitored changes in the surface chemistry of a Ni/GDC WE by combining NAP-XPS and impedance spectroscopy (IS). Researchers used a dual chamber NAP-XPS measurement cell with a three-electrode configuration, which provided the possibility of measuring the WE potential against a reference Pt electrode in a well-known atmosphere and monitoring the oxygen partial pressure on the studied electrode. Changes in the surface chemistry of the Ni/GDC electrode (i.e., the evolution of $\mathrm{Ni} 3 \mathrm{p}, \mathrm{Ce} 4 \mathrm{~d}$ and $\mathrm{O} 1 \mathrm{~s}$ regions) during its reduction at $923 \mathrm{~K}$ were monitored simultaneously with the electrochemical impedance properties of the electrode and results indicated that reduction of $\mathrm{Ce}^{4+}$ to $\mathrm{Ce}^{3+}$ species and $\mathrm{NiO}$ to metallic $\mathrm{Ni}$ occurred concurrently.

\subsection{2. $\mathrm{CH}_{4}$ Electro-Oxidation}

Direct feeding of the SOFCs anode with light hydrocarbons from fossil or renewable sources appears more attractive than the use of hydrogen as a fuel. Moreover, there is a significant interest in methane-fuelled SOFCs because $\mathrm{H}_{2}$ is mainly generated by the reforming of natural gas, mostly composed of $\mathrm{CH}_{4}$. It is known that direct feeding with methane can lead to the accumulation of carbon onto YSZ, but incorporation of ceria (in the form of GDC) limits this deposition and also improves the cell performance. Employing the same cell configuration, which consisted on an $80 \mu \mathrm{m}$ thick $\mathrm{NiO} / \mathrm{GDC}$ thin film anode on a YSZ electrolyte and a platinum film on the reverse side that acted as the cathode electrode, Papaefthimiou et al. [318] provided experimental evidence of the active surface oxidation state and composition of the anode during methane electro-oxidation ( 0.1 mbar pressure) at intermediate working temperatures $(973 \mathrm{~K})$. A mixture of reduced $\mathrm{Ni}^{0}$ and $\mathrm{Ce}^{3+}$ species in the anode, with an optimum Ni/Ce surface ratio close to 0.4 , was found to be the most favourable design to achieve maximum cell currents.

\subsection{3. $\mathrm{CO}_{2}$ Electrolysis/CO Electro-Oxidation}

Carbon dioxide can be used as a chemical feedstock in electrochemical systems, and this approach has become an interesting methodology for the production of hydrocarbon compounds, e.g., methane, methanol and carbon monoxide. Nevertheless, it is well-known that the activation and reduction of $\mathrm{CO}_{2}$ to $\mathrm{CO}$ and oxygen is a demanding task owing to the large positive enthalpy $(\Delta \mathrm{H}=283.0 \mathrm{~kJ} / \mathrm{mol})$ [319]. Recent investigations suggest that high-temperature electrolysis of $\mathrm{CO}_{2}$ using molten carbonates and solid oxide electrolysers of $\mathrm{CO}_{2}$ is one of the most promising and practical ways of $\mathrm{CO}_{2}$ reduction, exhibiting faster kinetics and higher selectivity. This approach was first pursued by NASA to generate $\mathrm{O}_{2}$ from the Martian atmosphere, rich in $\mathrm{CO}_{2}$ [320]. Two reports of ceria-based solid oxide $\mathrm{CO}_{2}$ electrolysis cells found in the literature study the carbon oxide chemistry $\left(\mathrm{CO}_{2}\right.$ electrolysis and $\mathrm{CO}$ electro-oxidation reactions) by means of ambient pressure XPS. On one hand, Yu et al. [303] designed a planar architecture SOC with both the ceria film WE and the $300 \mathrm{~nm} \mathrm{PtCE}$ patterned on the same side of the electrolyte, a polycrystalline YSZ substrate, and exposed to $0.65 \mathrm{mbar} \mathrm{CO}-\mathrm{CO}_{2}$ gas mixture at $873 \mathrm{~K}$ (see Figure 8). Researchers identified carbonate species $\left(\mathrm{CO}_{3}{ }^{2-}\right)$ on the ceria surface as reaction intermediates. When $\mathrm{CO}_{2}$ electrolysis is promoted on ceria electrodes at positively applied biases, a higher carbonate concentration over a $400 \mathrm{~mm}$-wide active region on the ceria surface is observed, while $\mathrm{CO}_{3}{ }^{2-}$ concentration appeared to decrease during $\mathrm{CO}$ electro-oxidation (see Figure 9). 


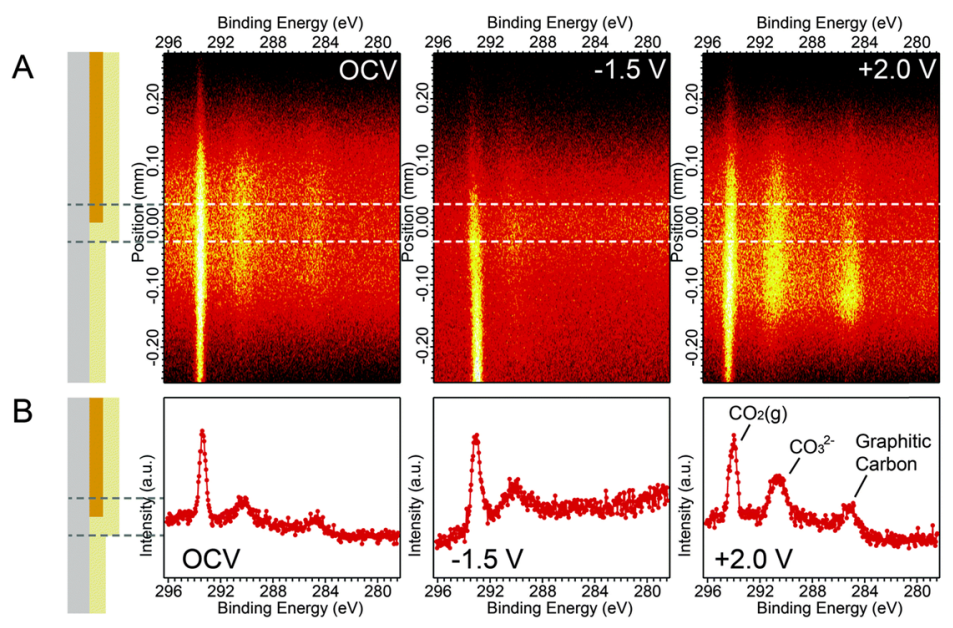

Figure 9. (A) Spatially-resolved NAP-XPS measurements of the C 1s obtained with a two-dimensional area detector at $0,-1.5$ and $+2.0 \mathrm{~V}$ applied potentials with $490 \mathrm{eV}$ photon energy. A corresponding schematic cell drawing is given on the left. (B) Integrated XPS spectra obtained by slicing a $60 \mu \mathrm{m}$-wide segment from the corresponding photoelectron signal in (A) at a position of $0.0 \mathrm{~mm}$. Intensities are normalised to the $\mathrm{CO}_{2}$ gas-phase peak. Reprinted with permission from [303], copyright 2014, Royal Society of Chemistry.

These results suggest that $\mathrm{CO}_{2}$ electrolysis reaction requires a pre-coordination of $\mathrm{CO}_{2}$ to the ceria surface to form a $\mathrm{CO}_{3}{ }^{2-}$ intermediate, and this reaction step precedes a rate-limiting electron transfer process involving carbonate reduction to give $\mathrm{CO}$ and oxide ions. This electron transfer step is also rate-limiting in the reverse direction.

On the other hand, Wang and Jackson [317] designed a two-sided electrochemical cell, with $300 \mathrm{~nm}$ thick Ni/GDC WE deposited onto $1 \mathrm{~mm}$-thick polycrystalline YSZ substrate and a porous Pt CE on the opposing side of the support. NAP-XPS measurements of $\mathrm{CO} / \mathrm{CO}_{2}$ surface electrochemistry on Ni/GDC were performed on the cell at $893 \mathrm{~K}$ and maintaining the total pressure around $0.5 \mathrm{mbar}$, with $\mathrm{P}_{\mathrm{CO}} / \mathrm{P}_{\mathrm{CO} 2}$ ratios at 1:1 and 1:9. Analysis demonstrated that dry $\mathrm{CO}$ oxidation and carbon dioxide dissociation are substantially slower than their $\mathrm{H}_{2}$ and $\mathrm{H}_{2} \mathrm{O}$ analogs on $\mathrm{Ni} / \mathrm{GDC}$ with current densities for $\mathrm{CO} / \mathrm{CO}_{2}$ roughly one order of magnitude lower than $\mathrm{H}_{2} / \mathrm{H}_{2} \mathrm{O}$. Operando XPS studies allowed obtaining local overpotentials and surface species factions across the $\mathrm{Ni} / \mathrm{GDC}$ interface.

\section{Summary and Outlook}

Near ambient pressure X-ray photoelectron spectroscopy (NAP-XPS) has been demonstrated to be a powerful tool to study the surface and subsurface of ceria-based catalysts under working conditions. The excellent oxygen storage capacity and redox properties of ceria due to the ability to accommodate a large number of oxygen vacancies in its structure can be studied in detail to ultimately obtain structure-activity relationships. As a support, ceria can strongly modify the reactivity of metal nanoparticles. The unique properties of ceria to provide surface oxygen species to the metal nanoparticles and their dynamic behaviour under reaction can be conveniently studied by NAP-XPS using different photon energies in synchrotron facilities to obtain information from different depths. This is particularly attractive for following segregation phenomena under reaction conditions in bimetallic catalysts. In turn, the presence of metal nanoparticles on ceria strongly modifies the reducibility of the support. This synergy originates complex systems and the use of NAP-XPS turns to be invaluable and necessary to get information about the nature of the metal-ceria interface. Due to its capabilities, NAP-XPS is one of the most demanded tools for the study of ceria-based catalysts, both for solid-liquid and solid-gas interfaces. NAP-XPS can provide not only information on the electronic state and surface composition of ceria and metal nanoparticles supported on it under a wide range of 
environmental conditions, but also information about adsorbed/desorbed molecules in the vicinity of the surface.

Author Contributions: X.G. drafted and wrote the original manuscript. All authors contributed to the final manuscript. C.E. and J.L. supervised the project. All authors have read and agreed to the published version of the manuscript.

Funding: This work has been funded by projects MICINN/FEDER RTI2018-093996-B-C31, RTI2018-093996-B-C32 and RTI2018-095498-J-I00 and GC 2017 SGR 128.

Acknowledgments: X.G. is grateful to FI-DGR 2016 grant. L.S. is grateful to the MICINN/FEDER for the project RTI2018-095498-J-I00. N.J. is grateful to 2018 BP 00146. X.V. is grateful to IJCI-2017-31449. I.L. is grateful to MINECO for Ph.D grant BES-2016-076507. J.L. is a Serra Húnter Fellow and is grateful to ICREA Academia program.

Conflicts of Interest: The authors declare no conflict of interest.

\section{Abbreviations}

\begin{tabular}{|c|c|c|c|}
\hline AFM & atomic force microscopy & POX & partial oxidation \\
\hline AP-IRRAS & ambient pressure IRRAS & PROX & preferential CO oxidation \\
\hline $\mathrm{CE}$ & counter electrode & RWGS & reverse water-gas shift \\
\hline CO-TPR & $\mathrm{CO}$ temperature-programmed reduction & ScSZ & scandia-stabilized zirconia \\
\hline DFT & density-functional theory & SDC & samaria-doped ceria \\
\hline DRB & dry reforming of butane & SEM & scanning electron microscopy \\
\hline DRE & dry reforming of ethane & SMSI & strong metal-support interaction \\
\hline DRIFTS & diffuse reflectance infrared Fourier transform spectroscopy & SOC & solid oxide electrochemical cell \\
\hline DRM & dry reforming of methane & SOEC & solid oxide electrolysis cell \\
\hline EXAFS & extended X-ray absorption fine structure & SOFC & solid oxide fuel cell \\
\hline FT & Fischer-Tropsch & SRE & steam reforming of ethanol \\
\hline GDC & gadolinium-doped ceria & SRM & steam reforming of methanol \\
\hline INS & inelastic neutron scattering & STM & scanning tunnelling microscopy \\
\hline IRRAS & infrared reflection absorption spectroscopy & STO & strontium titanate $\left(\mathrm{SrTiO}_{3}\right)$ \\
\hline LB & Langmuir-Blodgett & TR-XRD & time-resolved XRD \\
\hline LSCM & lanthanum strontium chromium manganite & TWC & three-way catalyst \\
\hline MIEC & mixed ionic-electronic conductor & UHV & ultra-high vacuum \\
\hline ML & monolayer & VOC & volatile organic compounds \\
\hline MPO & methane partial oxidation & WE & working electrode \\
\hline MPs & microparticles & WGS & water-gas shift \\
\hline NAP-XPS & near ambient pressure XPS & XANES & X-ray absorption near edge structure \\
\hline NEXAFS & near-edge $\mathrm{X}$-ray absorption fine structure & XAS & X-ray absorption spectroscopy \\
\hline NPs & nanoparticles & XPS & X-ray photoelectron spectroscopy \\
\hline OSC & oxygen storage capacity & $\mathrm{XRD}$ & X-ray diffraction \\
\hline OSR & oxidative steam reforming & YSZ & yttria-stabilized zirconia \\
\hline PEMFC & proton-exchange membrane fuel cell & $\Theta$ & coverage \\
\hline
\end{tabular}

\section{References}

1. Vivier, L.; Duprez, D. Ceria-Based Solid Catalysts for Organic Chemistry. ChemSusChem 2010, 3, $654-678$. [CrossRef]

2. Gorte, R.J. Ceria in Catalysis: From Automotive Applications to the Water-Gas Shift Reaction. AICHE J. 2010, 56, 1126-1135. [CrossRef]

3. Montini, T.; Melchionna, M.; Monai, M.; Fornasiero, P. Fundamentals and Catalytic Applications of $\mathrm{CeO}_{2}$-Based Materials. Chem. Rev. 2016, 116, 5987-6041. [CrossRef] [PubMed]

4. Trovarelli, A.; Llorca, J. Ceria Catalysts at Nanoscale: How Do Crystal Shapes Shape Catalysis? ACS Catal. 2017, 7, 4716-4735. [CrossRef]

5. Wang, Q.; Yeung, K.L.; Bañares, M.A. Ceria and its related materials for VOC catalytic combustion: A review. Catal. Today 2019. [CrossRef]

6. Liu, S.; Wu, X.; Weng, D.; Ran, R. Ceria-based catalysts for soot oxidation: A review. J. Rare Earths 2015, 33, 567-590. [CrossRef]

7. Aneggi, E.; Wiater, D.; De Leitenburg, C.; Llorca, J.; Trovarelli, A. Shape-Dependent Activity of Ceria in Soot Combustion. ACS Catal. 2014, 4, 172-181. [CrossRef] 
8. Mai, H.; Sun, L.; Zhang, Y.; Si, R.; Feng, W.; Zhang, H.; Liu, H.-C.; Yan, C.-H. Shape-Selective Synthesis and Oxygen Storage Behavior of Ceria Nanopolyhedra, Nanorods, and Nanocubes. J. Phys. Chem. B 2005, 109, 24380-24385. [CrossRef]

9. Conesa, J.C. Computer modeling of surfaces and defects on cerium dioxide. Surf. Sci. 1995, 339, $337-352$. [CrossRef]

10. Huang, W.; Gao, Y. Morphology-dependent surface chemistry and catalysis of $\mathrm{CeO}_{2}$ nanocrystals. Catal. Sci. Technol. 2014, 4, 3772-3784. [CrossRef]

11. Wu, K.; Sun, L.; Yan, C. Recent Progress in Well-Controlled Synthesis of Ceria-Based Nanocatalysts towards Enhanced Catalytic Performance. Adv. Energy Mater. 2016, 6, 1600501. [CrossRef]

12. Wang, Y.; Wöll, C. IR spectroscopic investigations of chemical and photochemical reactions on metal oxides: Bridging the materials gap. Chem. Soc. Rev. 2017, 46, 1875-1932. [CrossRef] [PubMed]

13. Nolan, M.; Grigoleit, S.; Sayle, D.C.; Parker, S.C.; Watson, G.W. Density functional theory studies of the structure and electronic structure of pure and defective low index surfaces of ceria. Surf. Sci. 2005, 576, 217-229. [CrossRef]

14. Branda, M.M.; Ferullo, R.M.; Caus, M.; Illas, F. Relative Stabilities of Low Index and Stepped CeO $\mathrm{S}_{2} \mathrm{Surfaces}$ from Hybrid and GGA+U Implementations of Density Functional Theory. J. Phys. Chem. C 2011, 115, 3716-3721. [CrossRef]

15. Yang, C.; Yu, X.; Heißler, S.; Nefedov, A.; Colussi, S.; Llorca, J.; Trovarelli, A.; Wang, Y.; Wöll, C. Surface Faceting and Reconstruction of Ceria Nanoparticles. Angew. Chem. Int. Ed. 2017, 56, 375-379. [CrossRef]

16. Aneggi, E.; Rico-Perez, V.; De Leitenburg, C.; Maschio, S.; Soler, L.; Llorca, J.; Trovarelli, A. Ceria-Zirconia Particles Wrapped in a 2D Carbon Envelope: Improved Low-Temperature Oxygen Transfer and Oxidation Activity. Angew. Chem. Int. Ed. 2015, 54, 14040-14043. [CrossRef]

17. Paier, J.; Penschke, C.; Sauer, J. Oxygen Defects and Surface Chemistry of Ceria: Quantum Chemical Studies Compared to Experiment. Chem. Rev. 2013, 113, 3949-3985. [CrossRef]

18. Aneggi, E.; Llorca, J.; Boaro, M.; Trovarelli, A. Surface-structure sensitivity of CO oxidation over polycrystalline ceria powders. J. Catal. 2005, 234, 88-95. [CrossRef]

19. Zhou, X.; Huebner, W. Size-induced lattice relaxation in $\mathrm{CeO}_{2}$ nanoparticles. Appl. Phys. Lett. 2001, 79, 3512-3514. [CrossRef]

20. Migani, A.; Vayssilov, G.N.; Bromley, S.T.; Illas, F.; Neyman, K.M. Dramatic reduction of the oxygen vacancy formation energy in ceria particles: A possible key to their remarkable reactivity at the nanoscale. J. Mater. Chem. 2010, 20, 10535-10546. [CrossRef]

21. Bruix, A.; Neyman, K.M. Modeling Ceria-Based Nanomaterials for Catalysis and Related Applications. Catal. Lett. 2016, 146, 2053-2080. [CrossRef]

22. Gatica, J.M.; Gómez, D.M.; Hernández-Garrido, J.C.; Calvino, J.J.; Cifredo, G.A.; Vidal, H. Experimental evidences of the relationship between reducibility and micro- and nanostructure in commercial high surface area ceria. Appl. Catal. A Gen. 2014, 479, 35-44. [CrossRef]

23. Aneggi, E.; Llorca, J.; Trovarelli, A.; Aouine, M.; Vernoux, P. In situ environmental HRTEM discloses low temperature carbon soot oxidation by ceria-zirconia at the nanoscale. Chem. Commun. 2019, 55, 3876-3878. [CrossRef] [PubMed]

24. Kullgren, J.; Hermansson, K.; Broqvist, P. Supercharged low-temperature oxygen storage capacity of ceria at the nanoscale. J. Phys. Chem. Lett. 2013, 4, 604-608. [CrossRef] [PubMed]

25. Guzman, J.; Carrettin, S.; Corma, A. Spectroscopic evidence for the supply of reactive oxygen during CO oxidation catalyzed by gold supported on nanocrystalline $\mathrm{CeO}_{2}$. J. Am . Chem. Soc. 2005, 127, 3286-3287. [CrossRef] [PubMed]

26. Xu, J.; Harmer, J.; Li, G.; Chapman, T.; Collier, P.; Longworth, S.; Tsang, S.C. Size dependent oxygen buffering capacity of ceria nanocrystals. Chem. Commun. 2010, 46, 1887-1889. [CrossRef]

27. Liu, X.; Zhou, K.; Wang, L.; Wang, B.; Li, Y. Oxygen Vacancy Clusters Promoting Reducibility and Activity of Ceria Nanorods. J. Am. Chem. Soc. 2009, 131, 3140-3141. [CrossRef]

28. Wang, L.; Wang, Y.; Zhang, Y.; Yu, Y.; He, H.; Qin, X.; Wang, B. Shape dependence of nanoceria on complete catalytic oxidation of o-xylene. Catal. Sci. Technol. 2016, 6, 4840-4848. [CrossRef]

29. Carrettin, S.; Concepción, P.; Corma, A.; López Nieto, J.M.; Puntes, V.F. Nanocrystalline $\mathrm{CeO}_{2}$ increases the activity of Au for CO oxidation by two orders of magnitude. Angew. Chem. Int. Ed. 2004, 43, 2538-2540. [CrossRef] 
30. Fu, Q.; Saltsburg, H.; Flytzani-stephanopoulos, M. Active Nonmetallic Au and Pt Species on Ceria-Based Water-Gas Shift Catalysts. Science 2003, 301, 935-939. [CrossRef] [PubMed]

31. Danielis, M.; Colussi, S.; De Leitenburg, C.; Soler, L.; Llorca, J.; Trovarelli, A. Outstanding Methane Oxidation Performance of Palladium-Embedded Ceria Catalysts Prepared by a One-Step Dry Ball-Milling Method. Angew. Chem. Int. Ed. 2018, 57, 10212-10216. [CrossRef]

32. Farmer, J.A.; Campbell, C.T. Ceria Maintains Smaller Metal Catalyst Particles by Strong Metal-Support Bonding. Science 2010, 329, 933-936. [CrossRef]

33. Jones, J.; Xiong, H.; DeLaRiva, A.T.; Peterson, E.J.; Pham, H.; Challa, S.R.; Qi, G.; Oh, S.; Wiebenga, M.H.; Hernández, X.I.P.; et al. Thermally stable single-atom platinum-on-ceria catalysts via atom trapping. Science 2016, 353, 150-154. [CrossRef] [PubMed]

34. Cargnello, M.; Doan-nguyen, V.V.T.; Gordon, T.R.; Diaz, R.E.; Stach, E.A.; Gorte, R.J.; Fornasiero, P.; Murray, C.B. Control of Metal Nanocrystal Size Reveals Metal-Support Interface Role for Ceria Catalysts. Science 2013, 341, 771-774. [CrossRef] [PubMed]

35. Rodriguez, J.A.; Grinter, D.C.; Liu, Z.; Palomino, R.M.; Senananayake, S.D. Ceria-based model catalysts: Fundamental studies on the importance of the metal-ceria interface in CO oxidation, the water-gas shift, $\mathrm{CO}_{2}$ hydrogenation, and methane and alcohol reforming. Chem. Soc. Rev. 2017, 46, 1824-1841. [CrossRef] [PubMed]

36. Trovarelli, A. Catalysis by Ceria and Related Materials; Imperial College Press: London, UK, 2002.

37. Rodriguez, J.A.; Senanayake, S.D.; Stacchiola, D.; Liu, P.; Hrbek, J. The activation of gold and the water-gas shift reaction: Insights from studies with model catalysts. Acc. Chem. Res. 2014, 47, 773-782. [CrossRef]

38. Vayssilov, G.N.; Lykhach, Y.; Migani, A.; Staudt, T.; Petrova, G.P.; Tsud, N.; Skála, T.; Bruix, A.; Illas, F.; Prince, K.C.; et al. Support nanostructure boosts oxygen transfer to catalytically active platinum nanoparticles. Nat. Mater. 2011, 10, 310-315. [CrossRef]

39. Mudiyanselage, K.; Senanayake, S.D.; Feria, L.; Kundu, S.; Baber, A.E.; Graciani, J.; Vidal, A.B.; Agnoli, S.; Evans, J.; Chang, R.; et al. Importance of the metal-oxide interface in catalysis: In situ studies of the water-gas shift reaction by ambient-pressure X-ray photoelectron spectroscopy. Angew. Chem. Int. Ed. 2013, 52, 5101-5105. [CrossRef]

40. Soler, L.; Casanovas, A.; Urrich, A.; Angurell, I.; Llorca, J. CO oxidation and COPrOx over preformed Au nanoparticles supported over nanoshaped $\mathrm{CeO}_{2}$. Appl. Catal. B Environ. 2016, 197, 47-55. [CrossRef]

41. Kim, H.Y.; Lee, H.M.; Henkelman, G. CO Oxidation Mechanism on $\mathrm{CeO}_{2}$-Supported Au Nanoparticles. J. Am. Chem. Soc. 2012, 134, 1560-1570. [CrossRef]

42. Patarroyo, J.; Delgado, J.A.; Merkoçi, F.; Genç, A.; Sauthier, G.; Llorca, J.; Arbiol, J.; Bastus, N.G.; Godard, C.; Claver, C.; et al. Hollow PdAg- $\mathrm{CeO}_{2}$ heterodimer nanocrystals as highly structured heterogeneous catalysts. Sci. Rep. 2019, 9, 18776. [CrossRef] [PubMed]

43. Nordling, C.; Sokolowski, E.; Siegbahn, K. Precision Method for Obtaining Absolute Values of Atomic Binding Energies. Phys. Rev. 1957, 105, 1676-1677. [CrossRef]

44. Siegbahn, K. ESCA: Atomic, Molecular and Solid State Structure Studied by Means of Electron Spectroscopy; Kunglia Vetenskap-Societeten Uppsala: Nova acta Regiae Societate's Uppsaliensis; Almqvist \& Wiksells: Uppsala, Sweden, 1967.

45. Rupprechter, G.; Weilach, C. Spectroscopic studies of surface-gas interactions and catalyst restructuring at ambient pressure: Mind the gap! J. Phys. Condens. Matter 2008, 20, 184019. [CrossRef]

46. Somorjai, G.A.; Frei, H.; Park, J.Y. Advancing the frontiers in nanocatalysis, biointerfaces, and renewable energy conversion by innovations of surface techniques. J. Am. Chem. Soc. 2009, 131, 16589-16605. [CrossRef] [PubMed]

47. Escudero, C.; Salmeron, M. From solid-vacuum to solid-gas and solid-liquid interfaces: In situ studies of structure and dynamics under relevant conditions. Surf. Sci. 2013, 607, 2-9. [CrossRef]

48. Siegbahn, K.; Nordling, C.; Johansson, G.; Hedman, J.; Hedén, P.F.; Hamrin, K.; Gelius, U.; Bergmark, T.; Werme, L.O.; Manne, R.; et al. ESCA Applied to Free Molecules; North-Holland Publishing Company: Amsterdam, The Netherlands, 1969.

49. Siegbahn, H.; Siegbahn, K. ESCA applied to liquids. J. Electron Spectros. Relat. Phenom. 1973, 2, $319-325$. [CrossRef]

50. Salmeron, M.; Schlögl, R. Ambient pressure photoelectron spectroscopy: A new tool for surface science and nanotechnology. Surf. Sci. Rep. 2008, 63, 169-199. [CrossRef] 
51. Ogletree, D.F.; Bluhm, H.; Lebedev, G.; Fadley, C.S.; Hussain, Z.; Salmeron, M. A differentially pumped electrostatic lens system for photoemission studies in the millibar range. Rev. Sci. Instrum. 2002, 73, 3872. [CrossRef]

52. Shavorskiy, A.; Karslioglu, O.; Zegkinoglou, I.; Bluhm, H. Synchrotron-based Ambient Pressure X-ray Photoelectron Spectroscopy. Synchrotron Radiat. News 2014, 27, 14-23. [CrossRef]

53. Arble, C.; Jia, M.; Newberg, J.T. Lab-based ambient pressure X-ray photoelectron spectroscopy from past to present. Surf. Sci. Rep. 2018, 73, 37-57. [CrossRef]

54. Trotochaud, L.; Head, A.R.; Karslioğlu, O.; Kyhl, L.; Bluhm, H. Ambient pressure photoelectron spectroscopy: Practical considerations and experimental frontiers. J. Phys. Condens. Matter 2017, 29, 053002. [CrossRef]

55. Lundgren, E.; Zhang, C.; Merte, L.R.; Shipilin, M.; Blomberg, S.; Hejral, U.; Zhou, J.; Zetterberg, J.; Gustafson, J. Novel in Situ Techniques for Studies of Model Catalysts. Acc. Chem. Res. 2017, 50, 2326-2333. [CrossRef] [PubMed]

56. Dou, J.; Sun, Z.; Opalade, A.A.; Wang, N.; Fu, W.; Tao, F. Operando chemistry of catalyst surfaces during catalysis. Chem. Soc. Rev. 2017, 46, 2001-2027. [CrossRef] [PubMed]

57. Alayoglu, S.; Somorjai, G.A. Ambient Pressure X-ray Photoelectron Spectroscopy for Probing Monometallic, Bimetallic and Oxide-Metal Catalysts under Reactive Atmospheres and Catalytic Reaction Conditions. Top. Catal. 2016, 59, 420-438. [CrossRef]

58. Wu, C.H.; Eren, B.; Salmeron, M.B. Structure and Dynamics of Reactant Coadsorption on Single Crystal Model Catalysts by HP-STM and AP-XPS: A Mini Review. Top. Catal. 2016, 59, 405-419. [CrossRef]

59. Toyoshima, R.; Kondoh, H. In-situ observations of catalytic surface reactions with soft x-rays under working conditions. J. Phys. Condens. Matter 2015, 27, 83003. [CrossRef]

60. Yoshida, M.; Kondoh, H. In Situ Observation of Model Catalysts under Reaction Conditions Using X-ray Core-Level Spectroscopy. Chem. Rec. 2014, 14, 806-818. [CrossRef] [PubMed]

61. Starr, D.E.; Bluhm, H.; Liu, Z.; Knop-Gericke, A.; Hävecker, M. Application of Ambient-Pressure X-ray Photoelectron Spectroscopy for the In-situ Investigation of Heterogeneous Catalytic Reactions. In In-situ Characterization of Heterogeneous Catalysts; John Wiley \& Sons, Inc.: Hoboken, NJ, USA, 2013; pp. 315-343.

62. Starr, D.E.; Liu, Z.; Hävecker, M.; Knop-Gericke, A.; Bluhm, H. Investigation of solid/vapor interfaces using ambient pressure X-ray photoelectron spectroscopy. Chem. Soc. Rev. 2013, 42, 5833-5857. [CrossRef]

63. Palomino, R.M.; Hamlyn, R.; Liu, Z.; Grinter, D.C.; Waluyo, I.; Rodriguez, J.A.; Senanayake, S.D. Interfaces in heterogeneous catalytic reactions: Ambient pressure XPS as a tool to unravel surface chemistry. J. Electron. Spectros. Relat. Phenom. 2017, 221, 28-43. [CrossRef]

64. Nguyen, L.; Tao, F.F.; Tang, Y.; Dou, J.; Bao, X. Understanding Catalyst Surfaces during Catalysis through Near Ambient Pressure X-ray Photoelectron Spectroscopy. Chem. Rev. 2019, 119, 6822-6905. [CrossRef]

65. Zhong, L.; Chen, D.; Zafeiratos, S. A mini review of in situ near-ambient pressure XPS studies on non-noble, late transition metal catalysts. Catal. Sci. Technol. 2019, 9, 3851-3867. [CrossRef]

66. Van Spronsen, M.A.; Frenken, J.W.; Groot, I.M. Surface science under reaction conditions: CO oxidation on Pt and Pd model catalysts. Chem. Soc. Rev. 2017, 46, 4347-4374. [CrossRef] [PubMed]

67. Tao, F.; Grass, M.E.; Zhang, Y.; Butcher, D.R.; Renzas, J.R.; Liu, Z.; Chung, J.Y.; Mun, B.S.; Salmeron, M.; Somorjai, G.A. Reaction-driven restructuring of Rh-Pd and Pt-Pd core-shell nanoparticles. Science 2008, 322, 932-934. [CrossRef]

68. Divins, N.J.; Angurell, I.; Escudero, C.; Pérez-Dieste, V.; Llorca, J. Influence of the support on surface rearrangements of bimetallic nanoparticles in real catalysts. Science 2014, 346, 620-623. [CrossRef] [PubMed]

69. Soler, L.; Casanovas, A.; Ryan, J.; Angurell, I.; Escudero, C.; Pérez-Dieste, V.; Llorca, J. Dynamic Reorganization of Bimetallic Nanoparticles under Reaction Depending on the Support Nanoshape: The Case of RhPd over Ceria Nanocubes and Nanorods under Ethanol Steam Reforming. ACS Catal. 2019, 9, 3641-3647. [CrossRef]

70. Crumlin, E.J.; Mutoro, E.; Hong, W.T.; Biegalski, M.D.; Christen, H.M.; Liu, Z.; Bluhm, H.; Shao-Horn, Y. In situ Ambient Pressure X-ray Photoelectron Spectroscopy of Cobalt Perovskite Surfaces under Cathodic Polarization at High Temperatures. J. Phys. Chem. C 2013, 117, 16087-16094. [CrossRef]

71. Knop-gericke, A.A.; Pfeifer, V.; Jones, T.; Arrigo, R.; Michael, H. In situ X-ray Photoelectron Spectroscopy of Electrochemically Active Solid-Gas and Solid-Liquid Interfaces. J. Electron Spectros. Relat. Phenom. 2017, 221, 10-17. [CrossRef]

72. Saveleva, V.A.; Savinova, E.R. Insights into electrocatalysis from ambient pressure photoelectron spectroscopy. Curr. Opin. Electrochem. 2019, 17, 79-89. [CrossRef] 
73. Friebel, D.; Ogasawara, H.; Nilsson, A. X-ray Spectroscopy at Electro-catalytic Interfaces. In Surface and Interface Science; John Wiley \& Sons, Ltd.: Hoboken, NJ, USA, 2020; pp. 733-772.

74. Starr, D.E.; Favaro, M.; Abdi, F.F.; Bluhm, H.; Crumlin, E.J.; Van de Krol, R. Combined soft and hard X-ray ambient pressure photoelectron spectroscopy studies of semiconductor/electrolyte interfaces. J. Electron. Spectros. Relat. Phenom. 2017, 221, 106-115. [CrossRef]

75. DeCaluwe, S.C.; Jackson, G.S.; Farrow, R.; McDaniel, A.; El Gabaly, F.; McCarty, K.; Nie, S.; Linne, M.; Bluhm, H.; Newberg, J.; et al. In Situ XPS for Evaluating Ceria Oxidation States in SOFC Anodes. ECS Trans. 2009, 16, 253-263.

76. Trovarelli, A. Catalytic properties of ceria and $\mathrm{CeO}_{2}$-containing materials. Catal. Rev. 1996, 38, 439-520. [CrossRef]

77. Tauster, S.J. Strong Metal-Support Interaction. Acc. Chem. Res. 1987, 20, 389-394. [CrossRef]

78. Datye, A.K.; Kalakkad, D.S.; Yao, M.H.; Smith, D.J. Comparison of metal-support interactions in Pt/TiO 2 and $\mathrm{Pt} / \mathrm{CeO}_{2}$. J. Catal. 1995, 155, 148-153. [CrossRef]

79. De Leitenburg, C.; Trovarelli, A. Metal-support interactions in $\mathrm{Rh} / \mathrm{CeO}_{2}, \mathrm{Rh} / \mathrm{TiO}_{2}$, and $\mathrm{Rh} / \mathrm{Nb}_{2} \mathrm{O}_{5}$ catalysts as inferred from $\mathrm{CO}_{2}$ methanation activity. J. Catal. 1995, 156, 171-174. [CrossRef]

80. Mogensen, M.; Sammes, N.M.; Tompsett, G.A. Physical, chemical and electrochemical properties of pure and doped ceria. Solid State Ion. 2000, 129, 63-94. [CrossRef]

81. Caballero, A.; Holgado, J.P.; Gonzalez-Delacruz, V.M.; Habas, S.E.; Herranz, T.; Salmeron, M. In situ spectroscopic detection of SMSI effect in a $\mathrm{Ni} / \mathrm{CeO}_{2}$ system: Hydrogen-induced burial and dig out of metallic nickel. Chem. Commun. 2010, 46, 1097-1099. [CrossRef]

82. Bernardi, F.; Grass, M.E.; Hong, Y.P.; Chang, R.; Jabeen, N.; Zhang, C.; Eichhorn, B.W.; Seo, B.; Alayoglu, S.; Hussain, Z.; et al. Control of the surface atomic population of $\mathrm{Rh}_{0.5} \mathrm{Pd}_{0.5}$ bimetallic nanoparticles supported on $\mathrm{CeO}_{2}$. Catal. Today 2016, 260, 95-99. [CrossRef]

83. Figueiredo, W.T.; Della Mea, G.B.; Segala, M.; Baptista, D.L.; Escudero, C.; Pérez-Dieste, V.; Bernardi, F. Understanding the Strong Metal-Support Interaction (SMSI) Effect in $\mathrm{Cu} \times \mathrm{Ni}_{1-\mathrm{x}} / \mathrm{CeO}_{2}(0<\mathrm{x}<1)$ Nanoparticles for Enhanced Catalysis. ACS Appl. Nano Mater. 2019, 2, 2559-2573.

84. Carrasco, J.; Lõpez-Durán, D.; Liu, Z.; Duchoň, T.; Evans, J.; Senanayake, S.D.; Crumlin, E.J.; Matolín, V.; Rodríguez, J.A.; Ganduglia-Pirovano, M.V. In situ and theoretical studies for the dissociation of water on an active $\mathrm{Ni} / \mathrm{CeO}_{2}$ Catalyst: Importance of strong metal-support interactions for the cleavage of $\mathrm{O}-\mathrm{H}$ bonds. Angew. Chem. Int. Ed. 2015, 54, 3917-3921. [CrossRef]

85. Sharma, S.; Hu, Z.; Zhang, P.; Mcfarland, E.W.; Metiu, H. $\mathrm{CO}_{2}$ methanation on Ru-doped ceria. J. Catal. 2011, 278, 297-309. [CrossRef]

86. Bunluesin, T.; Gorte, R.J.; Graham, G.W. Studies of the water-gas-shift reaction on ceria-supported Pt, Pd, and Rh: Implications for oxygen-storage properties. Appl. Catal. B Environ. 1998, 15, 107-114. [CrossRef]

87. Bernal, S.; Calvino, J.J.; Cauqui, M.A.; Gatica, J.M.; Larese, C.; Pérez Omil, J.A.; Pintado, J.M. Some recent results on metal/support interaction effects in $\mathrm{NM} / \mathrm{CeO}_{2}$ (NM: Noble metal) catalysts. Catal. Today 1999, 50, 175-206. [CrossRef]

88. Hilaire, S.; Wang, X.; Luo, T.; Gorte, R.J.; Wagner, J. A comparative study of water-gas-shift reaction over ceria supported metallic catalysts. Appl. Catal. A Gen. 2001, 215, 271-278. [CrossRef]

89. Sudarsanam, P.; Mallesham, B.; Reddy, P.S.; Großmann, D.; Grünert, W.; Reddy, B.M. Nano-Au / CeO catalysts for $\mathrm{CO}$ oxidation: Influence of dopants (Fe, $\mathrm{La}$ and $\mathrm{Zr}$ ) on the physicochemical properties and catalytic activity. Appl. Catal. B Environ. 2014, 144, 900-908. [CrossRef]

90. Aguilar-guerrero, V.; Gates, B.C. Kinetics of $\mathrm{CO}$ oxidation catalyzed by highly dispersed $\mathrm{CeO}_{2}$-supported gold. J. Catal. 2008, 260, 351-357. [CrossRef]

91. Fonseca, J.; Royer, S.; Bion, N.; Pirault-Roy, L.; Do Carmo Range, M.; Duprez, D.; Epron, F. Preferential CO oxidation over nanosized gold catalysts supported on ceria and amorphous ceria-alumina. Appl. Catal. B Environ. 2012, 128, 10-20. [CrossRef]

92. Liotta, L.F.; Pantaleo, G.; Puleo, F.; Venezia, A.M. Au/CeO $-\mathrm{SBA}-15$ catalysts for $\mathrm{CO}$ oxidation: Effect of ceria loading on physic-chemical properties and catalytic performances. Catal. Today 2012, 187, 10-19. [CrossRef]

93. Russo, N.; Fino, D.; Saracco, G.; Specchia, V. Supported gold catalysts for CO oxidation. Catal. Today 2006, 117, 214-219. [CrossRef]

94. Meyer, R.; Lemire, C.; Shaikhutdinov, S.K.; Freund, H. Surface Chemistry of Catalysis by Gold. Gold Bull. 2004, 37, 72-124. [CrossRef] 
95. Kang, M.; Song, M.W.; Lee, C.H. Catalytic carbon monoxide oxidation over $\mathrm{CoO}_{\mathrm{x}} / \mathrm{CeO}_{2}$ composite catalysts. Appl. Catal. A Gen. 2003, 251, 143-156. [CrossRef]

96. Qi, X.; Flytzani-Stephanopoulos, M. Activity and stability of $\mathrm{Cu}-\mathrm{CeO}_{2}$ catalysts in high-temperature water-gas shift for fuel-cell applications. Ind. Eng. Chem. Res. 2004, 43, 3055-3062. [CrossRef]

97. Lin, L.; Yao, S.; Liu, Z.; Zhang, F.; Li, N.; Vovchok, D.; Martínez-Arias, A.; Castaneda, R.; Lin, J.; Senanayake, S.D.; et al. In Situ Characterization of $\mathrm{Cu} / \mathrm{CeO}_{2}$ Nanocatalysts for $\mathrm{CO}_{2}$ Hydrogenation: Morphological Effects of Nanostructured Ceria on the Catalytic Activity. J. Phys. Chem. C 2018, 122, 12934-12943. [CrossRef]

98. Li, Y.; Fu, Q.; Flytzani-stephanopoulos, M. Low-temperature water-gas shift reaction over Cu- and Ni-loaded cerium oxide catalysts. Appl. Catal. B Environ. 2000, 27, 179-191. [CrossRef]

99. Alayoglu, S.; An, K.; Melaet, G.; Chen, S.; Bernardi, F.; Wang, L.W.; Lindeman, A.E.; Musselwhite, N.; Guo, J.; $\mathrm{Liu}, \mathrm{Z}$; ; et al. Pt-mediated reversible reduction and expansion of $\mathrm{CeO}_{2}$ in $\mathrm{Pt}$ nanoparticle/mesoporous $\mathrm{CeO}_{2}$ catalyst: In situ X-ray spectroscopy and diffraction studies under redox $\left(\mathrm{H}_{2}\right.$ and $\left.\mathrm{O}_{2}\right)$ atmospheres. J. Phys. Chem. C 2013, 117, 26608-26616. [CrossRef]

100. Kato, S.; Ammann, M.; Huthwelker, T.; Paun, C.; Lampimäki, M.; Lee, M.T.; Rothensteiner, M.; Van Bokhoven, J.A. Quantitative depth profiling of $\mathrm{Ce}^{3+}$ in $\mathrm{Pt} / \mathrm{CeO}_{2}$ by in situ high-energy XPS in a hydrogen atmosphere. Phys. Chem. Chem. Phys. 2015, 17, 5078-5083. [CrossRef]

101. Sohn, H.; Celik, G.; Gunduz, S.; Dogu, D.; Zhang, S.; Shan, J.; Tao, F.F.; Ozkan, U.S. Oxygen Mobility in Pre-Reduced Nano- and Macro-Ceria with Co Loading: An AP-XPS, In-Situ DRIFTS and TPR Study. Catal. Lett. 2017, 147, 2863-2876. [CrossRef]

102. Li, P.; Chen, X.; Li, Y.; Schwank, J.W. A review on oxygen storage capacity of $\mathrm{CeO}_{2}$-based materials: Influence factors, measurement techniques, and applications in reactions related to catalytic automotive emissions control. Catal. Today 2019, 327, 90-115. [CrossRef]

103. Singh, P.; Hegde, M.S.; Gopalakrishnan, J. $\mathrm{Ce}_{2 / 3} \mathrm{Cr}_{1 / 3} \mathrm{O}_{2+\mathrm{y}}$ : A new oxygen storage material based on the fluorite structure. Chem. Mater. 2008, 20, 7268-7273. [CrossRef]

104. Deng, C.; Li, M.; Qian, J.; Hu, Q.; Huang, M.; Lin, Q.; Ruan, Y.; Dong, L.; Li, B.; Fan, M. A Study of Different Doped Metal Cations on the Physicochemical Properties and Catalytic Activities of $\mathrm{Ce}_{20} \mathrm{M}_{1} \mathrm{O}_{\mathrm{x}}(\mathrm{M}=\mathrm{Zr}, \mathrm{Cr}$, $\mathrm{Mn}, \mathrm{Fe}, \mathrm{Co}, \mathrm{Sn}$ ) Composite Oxides for Nitric Oxide Reduction by Carbon Monoxide. Chem. An. Asian J. 2016, 11, 2144-2156. [CrossRef]

105. Jampaiah, D.; Venkataswamy, P.; Coyle, V.E.; Reddy, B.M.; Bhargava, S.K. Low-temperature CO oxidation over manganese, cobalt, and nickel doped $\mathrm{CeO}_{2}$ nanorods. RSC Adv. 2016, 6, 80541-80548. [CrossRef]

106. Lee, K.J.; Kim, Y.; Lee, J.H.; Cho, S.J.; Kwak, J.H.; Moon, H.R. Facile Synthesis and Characterization of Nanostructured Transition Metal/Ceria Solid Solutions $\left(\mathrm{TM}_{\mathrm{x}} \mathrm{Ce}_{1-\mathrm{x}} \mathrm{O}_{2-\delta}, \mathrm{TM}=\mathrm{Mn}, \mathrm{Ni}, \mathrm{Co}\right.$, or Fe) for CO Oxidation. Chem. Mater. 2017, 29, 2874-2882. [CrossRef]

107. Beckers, J.; Rothenberg, G. Redox properties of doped and supported copper-ceria catalysts. Dalt. Trans. 2008, 6573-6578. [CrossRef] [PubMed]

108. Xiong, Y.; Li, L.; Zhang, L.; Cao, Y.; Yu, S.; Tang, C.; Dong, L. Migration of copper species in $\mathrm{Ce}_{\mathrm{x}} \mathrm{Cu}_{1-\mathrm{x}} \mathrm{O}_{2}$ catalyst driven by thermal treatment and the effect on CO oxidation. Phys. Chem. Chem. Phys. 2017, 19, 21840-21847. [CrossRef] [PubMed]

109. Colón, G.; Pijolat, M.; Valdivieso, F.; Vidal, H.; Kašpar, J.; Finocchio, E.; Daturi, M.; Bernal, M.; Pijolat, F.; Valdivieso, H.; et al. Surface and structural characterization of $\mathrm{Ce}_{\mathrm{x}} \mathrm{Zr}_{1-\mathrm{x}} \mathrm{O}_{2}$ CEZIRENCAT mixed oxides as potential three-way catalyst promoters. J. Chem. Soc. Faraday Trans. 1998, 94, 3717-3726. [CrossRef]

110. Finocchio, E.; Daturi, M.; Binet, C.; Lavalley, J.C.; Flly, F.; Perrichon, V.; Vidal, H.; Kaspar, J.; Graziani, M.; Blanchard, G. Oxygen storage capacity improvement using $\mathrm{CeO}_{2}-\mathrm{ZrO}_{2}$ mixed oxides in three way catalysts. In Science and Technology in Catalysis 1998; Hattori, H., Otsuka, K., Eds.; Studies in Surface Science and Catalysis; Elsevier: Amsterdam, The Netherlands, 1999; Volume 121, pp. 257-262.

111. Daturi, M.; Finocchio, E.; Binet, C.; Lavalley, J.C.; Fally, F.; Perrichon, V. Study of Bulk and Surface Reduction by Hydrogen of $\mathrm{Ce}_{\mathrm{x}} \mathrm{Zr}_{1-\mathrm{x}} \mathrm{O}_{2}$ Mixed Oxides Followed by FTIR Spectroscopy and Magnetic Balance. J. Phys. Chem. B 1999, 103, 4884-4891. [CrossRef]

112. Wang, Y.; Liang, S.; Cao, A.; Thompson, R.L.; Veser, G. Au-mixed lanthanum/cerium oxide catalysts for water gas shift. Appl. Catal. B Environ. 2010, 99, 89-95. [CrossRef]

113. Liang, S.; Broitman, E.; Wang, Y.; Cao, A.; Veser, G. Highly stable, mesoporous mixed lanthanum-cerium oxides with tailored structure and reducibility. J. Mater. Sci. 2011, 46, 2928-2937. [CrossRef] 
114. Orge, C.A.; Órfão, J.J.M.; Pereira, M.F.R.; Duarte de Farias, A.M.; Fraga, M.A. Ceria and cerium-based mixed oxides as ozonation catalysts. Chem. Eng. J. 2012, 200-202, 499-505. [CrossRef]

115. Singh, P.; Hegde, M.S. $\mathrm{Ce}_{1-\mathrm{x}} \mathrm{Ru}_{\mathrm{x}} \mathrm{O}_{2-\delta}(\mathrm{x}=0.05,0.10)$ : A new high oxygen storage material and Pt, Pd-free three-way catalyst. Chem. Mater. 2009, 21, 3337-3345. [CrossRef]

116. Gayen, A.; Priolkar, K.R.; Sarode, P.R.; Jayaram, V.; Hegde, M.S.; Subbanna, G.N.; Emura, S. Ce $e_{1-x} \mathrm{Rh}_{x} \mathrm{O}_{2-\delta}$ solid solution formation in combustion-synthesized $\mathrm{Rh} / \mathrm{CeO}_{2}$ catalyst studied by XRD, TEM, XPS, and EXAFS. Chem. Mater. 2004, 16, 2317-2328. [CrossRef]

117. Kurnatowska, M.; Schuster, M.E.; Mista, W.; Kepinski, L. Self-regenerative property of nanocrystalline $\mathrm{Ce}_{0.89} \mathrm{M}_{0.11} \mathrm{O}_{2-\mathrm{y}}(\mathrm{M}=\mathrm{Pd}, \mathrm{Rh})$ mixed oxides. ChemCatChem 2014, 6, 3125-3131. [CrossRef]

118. Hiley, C.I.; Fisher, J.M.; Thompsett, D.; Kashtiban, R.J.; Sloan, J.; Walton, R.I. Incorporation of square-planar $\mathrm{Pd}^{2+}$ in fluorite $\mathrm{CeO}_{2}$ : Hydrothermal preparation, local structure, redox properties and stability. J. Mater. Chem. A 2015, 3, 13072-13079. [CrossRef]

119. Hegde, M.S.; Bera, P. Noble metal ion substituted $\mathrm{CeO}_{2}$ catalysts: Electronic interaction between noble metal ions and $\mathrm{CeO}_{2}$ lattice. Catal. Today 2015, 253, 40-50. [CrossRef]

120. Ikemoto, S.; Huang, X.; Muratsugu, S.; Nagase, S.; Koitaya, T.; Matsui, H.; Yokota, G.; Sudoh, T.; Hashimoto, A.; Tan, Y.; et al. Reversible low-temperature redox activity and selective oxidation catalysis derived from the concerted activation of multiple metal species on $\mathrm{Cr}$ and Rh-incorporated ceria catalysts. Phys. Chem. Chem. Phys. 2019, 21, 20868-20877. [CrossRef] [PubMed]

121. Della Mea, G.B.; Matte, L.P.; Thill, A.S.; Lobato, F.O.; Benvenutti, E.V.; Arenas, L.T.; Jürgensen, A.; Hergenröder, R.; Poletto, F.; Bernardi, F. Tuning the oxygen vacancy population of cerium oxide $\left(\mathrm{CeO}_{2-\mathrm{x}}\right.$, $0<\mathrm{x}<0.5)$ nanoparticles. Appl. Surf. Sci. 2017, 422, 1102-1112.

122. Pereira-Hernández, X.I.; DeLaRiva, A.; Muravev, V.; Kunwar, D.; Xiong, H.; Sudduth, B.; Engelhard, M.; Kovarik, L.; Hensen, E.J.M.; Wang, Y.; et al. Tuning $\mathrm{Pt}_{-} \mathrm{CeO}_{2}$ interactions by high-temperature vapor-phase synthesis for improved reducibility of lattice oxygen. Nat. Commun. 2019, 10,1-10. [CrossRef]

123. Sayle, T.X.T.; Caddeo, F.; Zhang, X.; Sakthivel, T.; Das, S.; Seal, S.; Ptasinska, S.; Sayle, D.C. Structure-Activity Map of Ceria Nanoparticles, Nanocubes, and Mesoporous Architectures. Chem. Mater. 2016, 28, 7287-7295. [CrossRef]

124. Gopal, C.B.; García-Melchor, M.; Lee, S.C.; Shi, Y.; Shavorskiy, A.; Monti, M.; Guan, Z.; Sinclair, R.; Bluhm, H.; Vojvodic, A.; et al. Equilibrium oxygen storage capacity of ultrathin $\mathrm{CeO}_{2-\delta}$ depends non-monotonically on large biaxial strain. Nat. Commun. 2017, 8, 1-12.

125. Bluhm, H.; Hävecker, M.; Knop-gericke, A.; Kiskinova, M.; Schlögl, R.; Salmeron, M. In Situ X-Ray Photoelectron Studies of Gas - Solid Interfaces at Near- Ambient Conditions. MRS Bull. 2007, 32, 1022-1030. [CrossRef]

126. Pozdnyakova, O.; Teschner, D.; Wootsch, A.; Kröhnert, J.; Steinhauer, B.; Sauer, H.; Toth, L.; Jentoft, F.C.; Knop-Gericke, A.; Paál, Z.; et al. Preferential CO oxidation in hydrogen (PROX) on ceria-supported catalysts, part I: Oxidation state and surface species on $\mathrm{Pt} / \mathrm{CeO}_{2}$ under reaction conditions. J. Catal. 2006, 237, 1-16. [CrossRef]

127. Pozdnyakova, O.; Teschner, D.; Wootsch, A.; Kröhnert, J.; Steinhauer, B.; Sauer, H.; Toth, L.; Jentoft, F.C.; Knop-Gericke, A.; Paál, Z.; et al. Preferential CO oxidation in hydrogen (PROX) on ceria-supported catalysts, part II: Oxidation states and surface species on $\mathrm{Pd} / \mathrm{CeO}_{2}$ under reaction conditions, suggested reaction mechanism. J. Catal. 2006, 237, 17-28. [CrossRef]

128. Teschner, D.; Wootsch, A.; Pozdnyakova-Tellinger, O.; Kröhnert, J.; Vass, E.M.; Hävecker, M.; Zafeiratos, S.; Schnörch, P.; Jentoft, P.C.; Knop-Gericke, A.; et al. Partial pressure dependent in situ spectroscopic study on the preferential CO oxidation in hydrogen (PROX) over Pt/ceria catalysts. J. Catal. 2007, 249, 318-327. [CrossRef]

129. Holgado, J.P.; Ternero, F.; Gonzalez-Delacruz, V.M.; Caballero, A. Promotional effect of the base metal on bimetallic $\mathrm{Au}-\mathrm{Ni} / \mathrm{CeO}_{2}$ catalysts prepared from core-shell nanoparticles. ACS Catal. 2013, 3, 2169-2180. [CrossRef]

130. Monte, M.; Munuera, G.; Costa, D.; Conesa, J.C.; Martínez-Arias, A. Near-ambient XPS characterization of interfacial copper species in ceria-supported copper catalysts. Phys. Chem. Chem. Phys. 2015, 17, 29995-30004. [CrossRef] 
131. Lukashuk, L.; Föttinger, K.; Kolar, E.; Rameshan, C.; Teschner, D.; Hävecker, M.; Knop-Gericke, A.; Yigit, N.; $\mathrm{Li}, \mathrm{H}$;; McDermott, E.; et al. Operando XAS and NAP-XPS studies of preferential CO oxidation on $\mathrm{Co}_{3} \mathrm{O}_{4}$ and $\mathrm{CeO}_{2}-\mathrm{Co}_{3} \mathrm{O}_{4}$ catalysts. J. Catal. 2016, 344, 1-15. [CrossRef]

132. Artiglia, L.; Orlando, F.; Roy, K.; Kopelent, R.; Safonova, O.; Nachtegaal, M.; Huthwelker, T.; Van Bokhoven, J.A. Introducing Time Resolution to Detect $\mathrm{Ce}^{3+}$ Catalytically Active Sites at the $\mathrm{Pt} / \mathrm{CeO}_{2}$ Interface through Ambient Pressure X-ray Photoelectron Spectroscopy. J. Phys. Chem. Lett. 2017, 8, 102-108. [CrossRef]

133. Wen, C.; Zhu, Y.; Ye, Y.; Zhang, S.; Cheng, F.; Liu, Y.; Wang, P.; Tao, F. Water-gas shift reaction on metal nanoclusters encapsulated in mesoporous ceria studied with ambient-pressure $\mathrm{X}$-ray photoelectron spectroscopy. ACS Nano 2012, 6, 9305-9313. [CrossRef]

134. Cámara, A.L.; Monte, M.; Martínez-Arias, A.; Conesa, J.C. XPS and DRIFTS operando studies of an inverse $\mathrm{CeO}_{2} / \mathrm{CuO}$ WGS catalyst: Deactivating role of interfacial carbonates in redox activity. Catal. Sci. Technol. 2012, 2, 2436-2439. [CrossRef]

135. Soler, L.; Casanovas, A.; Escudero, C.; Pérez-Dieste, V.; Aneggi, E.; Trovarelli, A.; Llorca, J. Ambient Pressure Photoemission Spectroscopy Reveals the Mechanism of Carbon Soot Oxidation in Ceria-Based Catalysts. ChemCatChem 2016, 8, 2748-2751. [CrossRef]

136. Graciani, J.; Mudiyanselage, K.; Xu, F.; Baber, A.E.; Evans, J.; Senanayake, S.D.; Stacchiola, D.J.; Liu, P.; Hrbek, J.; Fernández-Sanz, J.; et al. Highly active copper-ceria and copper-ceria-titania catalysts for methanol synthesis from CO2. Science 2014, 345, 2-6. [CrossRef]

137. Senanayake, S.D.; Ramírez, P.J.; Waluyo, I.; Kundu, S.; Mudiyanselage, K.; Liu, Z.; Liu, Z.; Axnanda, S.; Stacchiola, D.J.; Evans, J.; et al. Hydrogenation of $\mathrm{CO}_{2}$ to Methanol on $\mathrm{CeO}_{x} / \mathrm{Cu}(111)$ and $\mathrm{ZnO} / \mathrm{Cu}(111)$ Catalysts: Role of the Metal-Oxide Interface and Importance of $\mathrm{Ce}^{3+}$ Sites. J. Phys. Chem. C 2016, 120, 1778-1784. [CrossRef]

138. Winter, L.R.; Chen, R.; Chen, X.; Chang, K.; Liu, Z.; Senanayake, S.D.; Ebrahim, A.M.; Chen, J.G. Elucidating the roles of metallic $\mathrm{Ni}$ and oxygen vacancies in $\mathrm{CO}_{2}$ hydrogenation over $\mathrm{Ni} / \mathrm{CeO}_{2}$ using isotope exchange and in situ measurements. Appl. Catal. B Environ. 2019, 245, 360-366. [CrossRef]

139. Zhu, Y.; Zhang, S.; Shan, J.J.; Nguyen, L.; Zhan, S.; Gu, X.; Tao, F. In situ surface chemistries and catalytic performances of ceria doped with palladium, platinum, and rhodium in methane partial oxidation for the production of syngas. ACS Catal. 2013, 3, 2627-2639. [CrossRef]

140. Dou, J.; Tang, Y.; Nie, L.; Andolina, C.M.; Zhang, X.; House, S.; Li, Y.; Yang, J.; Tao, F. (Feng) Complete Oxidation of Methane on $\mathrm{Co}_{3} \mathrm{O}_{4} / \mathrm{CeO}_{2}$ Nanocomposite: A Synergic Effect. Catal. Today 2018, 311, 48-55. [CrossRef]

141. Zhang, X.; House, S.D.; Tang, Y.; Nguyen, L.; Li, Y.; Opalade, A.A.; Yang, J.C.; Sun, Z.; Tao, F.F. Complete Oxidation of Methane on NiO Nanoclusters Supported on $\mathrm{CeO}_{2}$ Nanorods through Synergistic Effect. ACS Sustain. Chem. Eng. 2018, 6, 6467-6477. [CrossRef]

142. Gonzalez-DelaCruz, V.M.; Holgado, J.P.; Pereñíguez, R.; Caballero, A. Morphology changes induced by strong metal-support interaction on a Ni-ceria catalytic system. J. Catal. 2008, 257, 307-314. [CrossRef]

143. Liu, Z.; Grinter, D.C.; Lustemberg, P.G.; Nguyen-Phan, T.D.; Zhou, Y.; Luo, S.; Waluyo, I.; Crumlin, E.J.; Stacchiola, D.J.; Zhou, J.; et al. Dry Reforming of Methane on a Highly-Active Ni-CeO ${ }_{2}$ Catalyst: Effects of Metal-Support Interactions on C-H Bond Breaking. Angew. Chem. Int. Ed. 2016, 55, 7455-7459. [CrossRef]

144. Lustemberg, P.G.; Ramírez, P.J.; Liu, Z.; Gutiérrez, R.A.; Grinter, D.G.; Carrasco, J.; Senanayake, S.D.; Rodriguez, J.A.; Ganduglia-Pirovano, M.V. Room-Temperature Activation of Methane and Dry Re-forming with $\mathrm{CO}_{2}$ on $\mathrm{Ni}-\mathrm{CeO}_{2}(111)$ Surfaces: Effect of $\mathrm{Ce}^{3+}$ Sites and Metal-Support Interactions on C-H Bond Cleavage. ACS Catal. 2016, 6, 8184-8191. [CrossRef]

145. Yan, B.; Yang, X.; Yao, S.; Wan, J.; Myint, M.N.Z.; Gomez, E.; Xie, Z.; Kattel, S.; Xu, W.; Chen, J.G. Dry Reforming of Ethane and Butane with $\mathrm{CO}_{2}$ over $\mathrm{PtNi} / \mathrm{CeO}_{2}$ Bimetallic Catalysts. ACS Catal. 2016, 6, 7283-7292. [CrossRef]

146. Liu, Z.; Lustemberg, P.; Gutiérrez, R.A.; Carey, J.J.; Palomino, R.M.; Vorokhta, M.; Grinter, D.C.; Ramírez, P.J.; Matolín, V.; Nolan, M.; et al. In Situ Investigation of Methane Dry Reforming on Metal/Ceria(111) Surfaces: Metal-Support Interactions and C-H Bond Activation at Low Temperature. Angew. Chem. Int. Ed. 2017, 56, 13041-13046. [CrossRef]

147. Zhang, F.; Liu, Z.; Zhang, S.; Akter, N.; Palomino, R.M.; Vovchok, D.; Orozco, I.; Salazar, D.; Rodriguez, J.A.; Llorca, J.; et al. In Situ Elucidation of the Active State of $\mathrm{Co}-\mathrm{CeO}_{x}$ Catalysts in the Dry Reforming of Methane: 
The Important Role of the Reducible Oxide Support and Interactions with Cobalt. ACS Catal. 2018, 8, 3550-3560. [CrossRef]

148. Xie, Z.; Yan, B.; Kattel, S.; Lee, J.H.; Yao, S.; Wu, Q.; Rui, N.; Gomez, E.; Liu, Z.; Xu, W.; et al. Dry reforming of methane over $\mathrm{CeO}_{2}$-supported Pt-Co catalysts with enhanced activity. Appl. Catal. B Environ. 2018, 236, 280-293. [CrossRef]

149. Liu, Z.; Zhang, F.; Rui, N.; Li, X.; Lin, L.; Betancourt, L.E.; Su, D.; Xu, W.; Cen, J.; Attenkofer, K.; et al. Highly Active Ceria-Supported Ru Catalyst for the Dry Reforming of Methane: In Situ Identification of $\mathrm{Ru}^{\delta+}-\mathrm{Ce}^{3+}$ Interactions for Enhanced Conversion. ACS Catal. 2019, 9, 3349-3359. [CrossRef]

150. Óvári, L.; Krick Calderon, S.; Lykhach, Y.; Libuda, J.; Erdohelyi, A.; Papp, C.; Kiss, J.; Steinrück, H.P. Near ambient pressure XPS investigation of the interaction of ethanol with $\mathrm{Co} / \mathrm{CeO}_{2}(111)$. J. Catal. 2013, 307, 132-139. [CrossRef]

151. Turczyniak, S.; Teschner, D.; Machocki, A.; Zafeiratos, S. Effect of the surface state on the catalytic performance of a $\mathrm{Co} / \mathrm{CeO}_{2}$ ethanol steam-reforming catalyst. J. Catal. 2016, 340, 321-330. [CrossRef]

152. Turczyniak, S.; Luo, W.; Papaefthimiou, V.; Ramgir, N.S.; Haevecker, M.; MacHocki, A.; Zafeiratos, S. A Comparative Ambient Pressure X-ray Photoelectron and Absorption Spectroscopy Study of Various Cobalt-Based Catalysts in Reactive Atmospheres. Top. Catal. 2016, 59, 532-542. [CrossRef]

153. Sohn, H.; Soykal, I.I.; Zhang, S.; Shan, J.; Tao, F.; Miller, J.T.; Ozkan, U.S. Effect of cobalt on reduction characteristics of ceria under ethanol steam reforming conditions: AP-XPS and XANES studies. J. Phys. Chem. C 2016, 120, 14631-14642. [CrossRef]

154. Liu, Z.; Duchoň, T.; Wang, H.; Grinter, D.C.; Waluyo, I.; Zhou, J.; Liu, Q.; Jeong, B.; Crumlin, E.J.; Matolín, V.; et al. Ambient pressure XPS and IRRAS investigation of ethanol steam reforming on $\mathrm{Ni}^{-\mathrm{CeO}_{2}(111)}$ catalysts: An in situ study of C-C and O-H bond scission. Phys. Chem. Chem. Phys. 2016, 18, 16621-16628. [CrossRef]

155. Liu, Z.; Yao, S.; Johnston-Peck, A.; Xu, W.; Rodriguez, J.A.; Senanayake, S.D. Methanol steam reforming over $\mathrm{Ni}-\mathrm{CeO}_{2}$ model and powder catalysts: Pathways to high stability and selectivity for $\mathrm{H}_{2} / \mathrm{CO}_{2}$ production. Catal. Today 2018, 311, 74-80. [CrossRef]

156. Mullins, D.R. Variations in the surface chemistry of methanol with $\mathrm{CeO}_{2}(100)$ at low and elevated pressures. Surf. Interface Anal. 2018, 50, 913-920. [CrossRef]

157. Wu, Z.; Cheng, Y.; Tao, F.; Daemen, L.; Foo, G.S.; Nguyen, L.; Zhang, X.; Beste, A.; Ramirez-Cuesta, A.J. Direct Neutron Spectroscopy Observation of Cerium Hydride Species on a Cerium Oxide Catalyst. J. Am. Chem. Soc. 2017, 139, 9721-9727. [CrossRef] [PubMed]

158. Mueanngern, Y.; Yang, X.; Tang, Y.; Tao, F.; Baker, L.R. Catalysis at Multiple Length Scales: Crotonaldehyde Hydrogenation at Nanoscale and Mesoscale Interfaces in Platinum-Cerium Oxide Catalysts. J. Phys. Chem. C 2017, 121, 13765-13776. [CrossRef]

159. Armor, J.N. The multiple roles for catalysis in the production of $\mathrm{H}_{2}$. Appl. Catal. A Gen. 1999, 176, $159-176$. [CrossRef]

160. Dudfield, C.D.; Chen, R.; Adcock, P.L. A carbon monoxide PROX reactor for PEM fuel cell automotive application. Int. J. Hydrog. Energy 2001, 26, 763-775. [CrossRef]

161. Kahlich, M.J.; Gasteiger, H.A.; Behm, R.J. Kinetics of the selective low-temperature oxidation of $\mathrm{CO}_{\text {in }} \mathrm{H}_{2}$-rich gas over $\mathrm{Au} / \alpha-\mathrm{Fe}_{2} \mathrm{O}_{3}$. J. Catal. 1999, 182, 430-440. [CrossRef]

162. Schubert, M.M.; Kahlich, M.J.; Gasteiger, H.A.; Behm, R.J. Correlation between CO surface coverage and selectivity/kinetics for the preferential CO oxidation over $\mathrm{Pt} / \gamma-\mathrm{Al}_{2} \mathrm{O}_{3}$ and $\mathrm{Au} / \alpha-\mathrm{Fe}_{2} \mathrm{O}_{3}$ : An in-situ DRIFTS study. J. Power Sources 1999, 84, 175-182. [CrossRef]

163. Bethke, G.K.; Kung, H.H. Selective $\mathrm{CO}$ oxidation in a hydrogen-rich stream over $\mathrm{Au} / \gamma-\mathrm{Al}_{2} \mathrm{O}_{3}$ catalysts. Appl. Catal. A Gen. 2000, 194-195, 43-53. [CrossRef]

164. Avgouropoulos, G.; Ioannides, T.; Papadopoulou, C.; Batista, J.; Hocevar, S.; Matralis, H.K. A comparative study of $\mathrm{Pt} / \gamma-\mathrm{Al}_{2} \mathrm{O}_{3}, \mathrm{Au} / \alpha-\mathrm{Fe}_{2} \mathrm{O}_{3}$ and $\mathrm{CuO}-\mathrm{CeO}_{2}$ catalysts for the selective oxidation of carbon monoxide in excess hydrogen. Catal. Today 2002, 75, 157-167. [CrossRef]

165. Oh, S.H.; Sinkevitch, R.M. Carbon Monoxide Removal from Hydrogen-Rich Fuel Cell Feedstreams by Selective Catalytic Oxidation. J. Catal. 1993, 142, 254-262. [CrossRef]

166. Kahlich, M.J.; Gasteiger, H.A.; Behm, R.J. Kinetics of the Selective CO Oxidation in $\mathrm{H}_{2}-\mathrm{Rich}_{\mathrm{Gas}}$ on $\mathrm{Pt} / \mathrm{Al}_{2} \mathrm{O}_{3}$. J. Catal. 1997, 171, 93-105. [CrossRef] 
167. Özkara, Ş.; Aksoylu, A.E. Selective low temperature carbon monoxide oxidation in $\mathrm{H}_{2}$-rich gas streams over activated carbon supported catalysts. Appl. Catal. A Gen. 2003, 251,75-83. [CrossRef]

168. Han, Y.-F.; Kahlich, M.J.; Kinne, M.; Behm, R.J. Kinetic study of selective CO oxidation in $\mathrm{H}_{2}$-rich gas on a $\mathrm{Ru} / \gamma-\mathrm{Al}_{2} \mathrm{O}_{3}$ catalyst. Phys. Chem. Chem. Phys. 2002, 4, 389-397. [CrossRef]

169. Jacobs, G.; Williams, L.; Graham, U.; Sparks, D.; Davis, B.H. Low-Temperature Water-Gas Shift: In-Situ DRIFTS-Reaction Study of a $\mathrm{Pt} / \mathrm{CeO}_{2}$ Catalyst for Fuel Cell Reformer Applications. J. Phys. Chem. B 2003, 107, 10398-10404. [CrossRef]

170. Johansson, S.; Österlund, L.; Kasemo, B. CO Oxidation Bistability Diagrams for Pt/CeO $\mathrm{x}_{\mathrm{x}}$ and $\mathrm{Pt} / \mathrm{SiO}_{2} \mathrm{Model}$ Catalysts Prepared by Electron-Beam Lithography. J. Catal. 2001, 201, 275-285. [CrossRef]

171. Bunluesin, T.; Cordatos, H.; Gorte, R.J. Study of CO Oxidation Kinetics on Rh/Ceria. J. Catal. 1995, 157, 222-226. [CrossRef]

172. Bekyarova, E.; Fornasiero, P.; Kašpar, J.; Graziani, M. CO oxidation on $\mathrm{Pd} / \mathrm{CeO}_{2}-\mathrm{ZrO}_{2}$ catalysts. Catal. Today 1998, 45, 179-183. [CrossRef]

173. Kaspar, J.; Fornasiero, P.; Graziani, M. Use of $\mathrm{CeO}_{2}$-based oxides in the three-way catalysis. Catal. Today 1999, 50, 285-298. [CrossRef]

174. Kopelent, R.; Van Bokhoven, J.A.; Szlachetko, J.; Edebeli, J.; Paun, C.; Nachtegaal, M.; Safonova, O. V Catalytically Active and Spectator $\mathrm{Ce}^{3+}$ in Ceria-Supported Metal Catalysts. Angew. Chem. Int. Ed. 2015, 54, 8728-8731. [CrossRef]

175. Penkala, B.; Aubert, D.; Kaper, H.; Tardivat, C.; Conder, K.; Paulus, W. The role of lattice oxygen in CO oxidation over $\mathrm{Ce}^{18} \mathrm{O}_{2}$-based catalysts revealed under operando conditions. Catal. Sci. Technol. 2015, 5, 4839-4848. [CrossRef]

176. Wang, X.; Rodriguez, J.A.; Hanson, J.C.; Gamarra, D.; Martínez-Arias, A.; Fernández-García, M. In Situ Studies of the Active Sites for the Water Gas Shift Reaction over $\mathrm{Cu}-\mathrm{CeO}_{2}$ Catalysts: Complex Interaction between Metallic Copper and Oxygen Vacancies of Ceria. J. Phys. Chem. B 2006, 110, 428-434. [CrossRef]

177. Gamarra, D.; Belver, C.; Fernández-García, M.; Martínez-Arias, A. Selective CO Oxidation in Excess $\mathrm{H}_{2}$ over Copper-Ceria Catalysts: Identification of Active Entities/Species. J. Am. Chem. Soc. 2007, 129, 12064-12065. [CrossRef] [PubMed]

178. Jia, A.-P.; Jiang, S.-Y.; Lu, J.-Q.; Luo, M.-F. Study of Catalytic Activity at the CuO-CeO 2 Interface for CO Oxidation. J. Phys. Chem. C 2010, 114, 21605-21610. [CrossRef]

179. Gamarra, D.; Cámara, A.L.; Monte, M.; Rasmussen, S.B.; Chinchilla, L.E.; Hungría, A.B.; Munuera, G.; Gyorffy, N.; Schay, Z.; Corberán, V.C.; et al. Preferential oxidation of $\mathrm{CO}$ in excess $\mathrm{H}_{2}$ over $\mathrm{CuO} / \mathrm{CeO}_{2}$ catalysts: Characterization and performance as a function of the exposed face present in the $\mathrm{CeO}_{2}$ support. Appl. Catal. B Environ. 2013, 130-131, 224-238. [CrossRef]

180. Arango-Díaz, A.; Moretti, E.; Talon, A.; Storaro, L.; Lenarda, M.; Núñez, P.; Marrero-Jerez, J.; Jiménez-Jiménez, J.; Jiménez-López, A.; Rodríguez-Castellón, E. Preferential CO oxidation (CO-PROX) catalyzed by $\mathrm{CuO}$ supported on nanocrystalline $\mathrm{CeO}_{2}$ prepared by a freeze-drying method. Appl. Catal. A Gen. 2014, 477, 54-63. [CrossRef]

181. Teng, Y.; Sakurai, H.; Ueda, A.; Kobayashi, T. Oxidative removal of CO contained in hydrogen by using metal oxide catalysts. Int. J. Hydrog. Energy 1999, 24, 355-358. [CrossRef]

182. Zhao, Z.; Yung, M.M.; Ozkan, U.S. Effect of support on the preferential oxidation of CO over cobalt catalysts. Catal. Commun. 2008, 9, 1465-1471. [CrossRef]

183. Woods, M.P.; Gawade, P.; Tan, B.; Ozkan, U.S. Preferential oxidation of carbon monoxide on $\mathrm{Co} / \mathrm{CeO} 2$ nanoparticles. Appl. Catal. B Environ. 2010, 97, 28-35. [CrossRef]

184. Gawade, P.; Bayram, B.; Alexander, A.-M.C.; Ozkan, U.S. Preferential oxidation of CO (PROX) over $\mathrm{CoO}_{x} / \mathrm{CeO}_{2}$ in hydrogen-rich streams: Effect of cobalt loading. Appl. Catal. B Environ. 2012, 128, 21-30. [CrossRef]

185. Gorte, R.J.; Zhao, S. Studies of the water-gas-shift reaction with ceria-supported precious metals. Catal. Today 2005, 104, 18-24. [CrossRef]

186. Fu, Q.; Weber, A.; Flytzani-Stephanopoulos, M. Nanostructured Au-CeO $\mathrm{O}_{2}$ catalysts for low-temperature water-gas shift. Catal. Lett. 2001, 77, 87-95. [CrossRef]

187. Rodriguez, J.A.; Graciani, J.; Evans, J.; Park, J.B.; Yang, F.; Stacchiola, D.; Senanayake, S.D.; Ma, S.; Perez, M.; Liu, P.; et al. Water-gas shift reaction on a highly active inverse $\mathrm{CeO}_{x} / \mathrm{Cu}(111)$ catalyst: Unique role of ceria nanoparticles. Angew. Chem. Int. Ed. 2009, 48, 8047-8050. [CrossRef] [PubMed] 
188. Barrio, L.; Estrella, M.; Zhou, G.; Wen, W.; Hanson, J.C.; Hungría, A.B.; Hornés, A.; Fernández-García, M.; Martínez-Arias, A.; Rodriguez, J.A. Unraveling the Active Site in Copper-Ceria Systems for the Water-Gas Shift Reaction: In Situ Characterization of an Inverse Powder $\mathrm{CeO}_{2-\mathrm{x}} / \mathrm{CuO}-\mathrm{Cu}$ Catalyst. J. Phys. Chem. C 2010, 114, 3580-3587. [CrossRef]

189. Senanayake, S.D.; Stacchiola, D.; Evans, J.; Estrella, M.; Barrio, L.; Pérez, M.; Hrbek, J.; Rodriguez, J.A. Probing the reaction intermediates for the water-gas shift over inverse $\mathrm{CeO}_{x} / \mathrm{Au}(111)$ catalysts. J. Catal. 2010, 271, 392-400. [CrossRef]

190. Stanmore, B.R.; Brilhac, J.F.; Gilot, P. The oxidation of soot: A review of experiments, mechanisms and models. Carbon 2001, 39, 2247-2268. [CrossRef]

191. Van Setten, B.A.; Makkee, M.; Moulijn, J.A. Science and technology of catalytic diesel particulate filters. Catal. Rev. 2001, 43, 489-564. [CrossRef]

192. Bueno-López, A. Diesel soot combustion ceria catalysts. Appl. Catal. B Environ. 2014, 146, 1-11. [CrossRef]

193. Fino, D.; Specchia, V. Open issues in oxidative catalysis for diesel particulate abatement. Powder Technol. 2008, 180, 64-73. [CrossRef]

194. Darcy, P.; Da Costa, P.; Mellottée, H.; Trichard, J.-M.; Djéga-Mariadassou, G. Kinetics of catalyzed and non-catalyzed oxidation of soot from a diesel engine. Catal. Today 2007, 119, 252-256. [CrossRef]

195. Kim, G. Ceria-Promoted Three-Way Catalysts for Auto Exhaust Emission Control. Ind. Eng. Chem. Prod. Res. Dev. 1982, 21, 267-274. [CrossRef]

196. Yao, H.C.; Yao, Y.Y. Ceria in Automotive Exhaust Catalysts: I. Oxygen storage. J. Catal. 1984, 86, $254-265$. [CrossRef]

197. Trovarelli, A.; De Leitenburg, C.; Boaro, M.; Dolcetti, G. The utilization of ceria in industrial catalysis. Catal. Today 1999, 50, 353-367. [CrossRef]

198. Aneggi, E.; De Leitenburg, C.; Trovarelli, A. Ceria-Based Formulations for Catalysis for Diesel Soot Combustion. In Catalysis by Ceria and Related Materials; Trovarelli, A., Fornasiero, P., Eds.; World Scientific: Singapore, 2013; pp. 565-621.

199. Harada, K.; Oishi, T.; Hamamoto, S.; Ishihara, T. Lattice Oxygen Activity in Pr- and La-Doped $\mathrm{CeO}_{2}$ for Low-Temperature Soot Oxidation. J. Phys. Chem. C 2014, 118, 559-568. [CrossRef]

200. Pushkarev, V.V.; Kovalchuk, V.I.; Itri, J.L. Probing Defect Sites on the $\mathrm{CeO}_{2}$ Surface with Dioxygen. J. Phys. Chem. B 2004, 108, 5341-5348. [CrossRef]

201. Saab, E.; Abi-Aad, E.; Bokova, M.N.; Zhilinskaya, E.A.; Abouka1, A. EPR characterisation of carbon black in loose and tight contact with $\mathrm{Al}_{2} \mathrm{O}_{3}$ and $\mathrm{CeO}_{2}$ catalysts. Carbon 2007, 45, 561-567. [CrossRef]

202. Preda, G.; Migani, A.; Neyman, K.M.; Bromley, S.T.; Illas, F.; Pacchioni, G.; Milano, I. Formation of Superoxide Anions on Ceria Nanoparticles by Interaction of Molecular Oxygen with $\mathrm{Ce}^{3+}$ Sites. J. Phys. Chem. C 2011, 115, 5817-5822. [CrossRef]

203. Machida, M.; Murata, Y.; Kishikawa, K.; Zhang, D.; Ikeue, K. On the Reasons for High Activity of $\mathrm{CeO}_{2}$ Catalyst for Soot Oxidation. Chem. Mater. 2008, 20, 4489-4494. [CrossRef]

204. Gross, M.S.; Ulla, M.A.; Querini, C.A. Diesel particulate matter combustion with $\mathrm{CeO}_{2}$ as catalyst. Part I: System characterization and reaction mechanism. J. Mol. Catal. A Chem. 2012, 352, 86-94. [CrossRef]

205. Holgado, J.P.; Munuera, G.; Espinos, J.P.; González-Elipe, A.R. XPS study of oxidation processes of $\mathrm{CeO}_{\mathrm{x}}$ defective layers. Appl. Surf. Sci. 2000, 158, 164-171. [CrossRef]

206. Behrens, M.; Studt, F.; Kasatkin, I.; Kühl, S.; Hävecker, M.; Abild-Pedersen, F.; Zander, S.; Girgsdies, F.; Kurr, P.; Kniep, B.-L.; et al. The Active Site of Methanol Synthesis over $\mathrm{Cu} / \mathrm{ZnO} / \mathrm{Al}_{2} \mathrm{O}_{3}$ Industrial Catalysts. Science 2012, 336, 893-897. [CrossRef]

207. Yang, Y.; Evans, J.; Rodriguez, J.A.; White, M.G.; Liu, P. Fundamental studies of methanol synthesis from $\mathrm{CO}_{2}$ hydrogenation on $\mathrm{Cu}(111)$, $\mathrm{Cu}$ clusters, and $\mathrm{Cu} / \mathrm{ZnO}(000)$. Phys. Chem. Chem. Phys. 2010, 12, 9909-9917. [CrossRef]

208. Rasmussen, P.B.; Kazuta, M.; Chorkendorff, I. Synthesis of methanol from a mixture of $\mathrm{H}_{2}$ and $\mathrm{CO}_{2}$ on $\mathrm{Cu}(100)$. Surf. Sci. 1994, 318, 267-280. [CrossRef]

209. Yoshihara, J.; Campbell, C.T. Methanol Synthesis and Reverse Water-Gas Shift Kinetics over Cu(110) Model Catalysts: Structural Sensitivity. J. Catal. 1996, 161, 776-782. [CrossRef]

210. Yang, Y.; White, M.G.; Liu, P. Theoretical Study of Methanol Synthesis from $\mathrm{CO}_{2}$ Hydrogenation on Metal-Doped Cu(111) Surfaces. J. Phys. Chem. C 2012, 116, 248-256. [CrossRef] 
211. Kondratenko, E.V.; Mul, G.; Baltrusaitis, J.; Larrazábal, G.O.; Pérez-Ramírez, J. Status and perspectives of $\mathrm{CO}_{2}$ conversion into fuels and chemicals by catalytic, photocatalytic and electrocatalytic processes. Energy Environ. Sci. 2013, 6, 3112-3135. [CrossRef]

212. Quadrelli, E.A.; Centi, G.; Duplan, J.-L.; Perathoner, S. Carbon Dioxide Recycling: Emerging Large-Scale Technologies with Industrial Potential. ChemSusChem 2011, 4, 1194-1215. [CrossRef] [PubMed]

213. Preti, D.; Resta, C.; Squarcialupi, S.; Fachinetti, G. Carbon Dioxide Hydrogenation to Formic Acid by Using a Heterogeneous Gold Catalyst. Angew. Chem. Int. Ed. 2011, 50, 12551-12554. [CrossRef]

214. Ansari, M.B.; Min, B.-H.; Mo, Y.-H.; Park, S.-E. $\mathrm{CO}_{2}$ activation and promotional effect in the oxidation of cyclic olefins over mesoporous carbon nitrides. Green Chem. 2011, 13, 1416-1421. [CrossRef]

215. Vidal, A.B.; Feria, L.; Evans, J.; Takahashi, Y.; Liu, P.; Nakamura, K.; Illas, F.; Rodriguez, J.A. CO 2 Activation and Methanol Synthesis on Novel Au/TiC and Cu/TiC Catalysts. J. Phys. Chem. Lett. 2012, 3, 2275-2280. [CrossRef]

216. Miguel, C.V.; Soria, M.A.; Mendes, A.; Madeira, L.M. Direct $\mathrm{CO}_{2}$ hydrogenation to methane or methanol from post-combustion exhaust streams-A thermodynamic study. J. Nat. Gas. Sci. Eng. 2015, 22, 1-8. [CrossRef]

217. Torrente-Murciano, L.; Mattia, D.; Jones, M.D.; Plucinski, P.K. Formation of hydrocarbons via $\mathrm{CO}_{2}$ hydrogenation-A thermodynamic study. J. CO2 Util. 2014, 6, 34-39. [CrossRef]

218. Medford, A.J.; Lausche, A.C.; Abild-Pedersen, F.; Temel, B.; Schjødt, N.C.; Nørskov, J.K.; Studt, F. Activity and Selectivity Trends in Synthesis Gas Conversion to Higher Alcohols. Top. Catal. 2014, 57, 135-142. [CrossRef]

219. Studt, F.; Behrens, M.; Kunkes, E.L.; Thomas, N.; Zander, S.; Tarasov, A.; Schumann, J.; Frei, E.; Varley, J.B.; Abild-Pedersen, F.; et al. The Mechanism of $\mathrm{CO}$ and $\mathrm{CO}_{2}$ Hydrogenation to Methanol over Cu-Based Catalysts. ChemCatChem 2015, 7, 1105-1111. [CrossRef]

220. Lunkenbein, T.; Schumann, J.; Behrens, M.; Schlögl, R.; Willinger, M.G. Formation of a ZnO Overlayer in Industrial $\mathrm{Cu} / \mathrm{ZnO} / \mathrm{Al}_{2} \mathrm{O}_{3}$ Catalysts Induced by Strong Metal-Support Interactions. Angew. Chem. Int. Ed. 2015, 54, 4544-4548. [CrossRef] [PubMed]

221. Slaa, J.C.; Van Ommen, J.G.; Ross, J.R.H. The synthesis of higher alcohols using modified Cu/ $/ \mathrm{ZnO} / \mathrm{Al}_{2} \mathrm{O}_{3}$ catalysts. Catal. Today 1992, 15, 129-148. [CrossRef]

222. Nakamura, J.; Nakamura, I.; Uchijima, T.; Kanai, Y.; Watanabe, T.; Saito, M.; Fujitani, T. A Surface Science Investigation of Methanol Synthesis over a Zn-Deposited Polycrystalline Cu Surface. J. Catal. 1996, 160, 65-75. [CrossRef]

223. Schumann, J.; Eichelbaum, M.; Lunkenbein, T.; Thomas, N.; Álvarez Galván, M.C.; Schlögl, R.; Behrens, M. Promoting Strong Metal Support Interaction: Doping ZnO for Enhanced Activity of Cu/ZnO:M (M = Al, Ga, Mg) Catalysts. ACS Catal. 2015, 5, 3260-3270. [CrossRef]

224. Kandemir, T.; Kasatkin, I.; Girgsdies, F.; Zander, S.; Kühl, S.; Tovar, M.; Schlögl, R.; Behrens, M. Microstructural and Defect Analysis of Metal Nanoparticles in Functional Catalysts by Diffraction and Electron Microscopy: The Cu/ZnO Catalyst for Methanol Synthesis. Top. Catal. 2014, 57, 188-206. [CrossRef]

225. Rostrup-Nielsen, J.R. New aspects of syngas production and use. Catal. Today 2000, 63, 159-164. [CrossRef]

226. Reyes, S.C.; Sinfelt, J.H.; Feeley, J.S. Evolution of Processes for Synthesis Gas Production: Recent Developments in an Old Technology. Ind. Eng. Chem. Res. 2003, 42, 1588-1597. [CrossRef]

227. Liander, H. The utilisation of natural gases for the ammonia process. Trans. Faraday Soc. 1929, $25,462$. [CrossRef]

228. Goetsch, D.A.; Schmidt, L.D. Microsecond Catalytic Partial Oxidation of Alkanes. Science 1996, 271, $1560-1562$. [CrossRef]

229. Tsang, S.C.; Claridge, J.B.; Green, M.L. Recent advances in the conversion of methane to synthesis gas. Catal. Today 1995, 23, 3-15. [CrossRef]

230. York, A.P.E.; Xiao, T.; Green, M.L.H. Brief overview of the partial oxidation of methane to synthesis gas. Top. Catal. 2003, 22, 345-358. [CrossRef]

231. Wilson, J.N.; Pedigo, R.A.; Zaera, F. Kinetics and Mechanism of Catalytic Partial Oxidation Reactions of Alkanes on Rhodium Surfaces. J. Am. Chem. Soc. 2008, 130, 15796-15797. [CrossRef]

232. Christian Enger, B.; Lødeng, R.; Holmen, A. A review of catalytic partial oxidation of methane to synthesis gas with emphasis on reaction mechanisms over transition metal catalysts. Appl. Catal. A Gen. 2008, 346, 1-27. [CrossRef]

233. Basile, F.; Benito, P.; Fornasari, G.; Monti, M.; Scavetta, E.; Tonelli, D.; Vaccari, A. Novel Rh-based structured catalysts for the catalytic partial oxidation of methane. Catal. Today 2010, 157, 183-190. [CrossRef] 
234. Ashcroft, A.T.; Cheetham, A.K.; Foord, J.S.; Green, M.L.H.; Grey, C.P.; Murrell, A.J.; Vernon, P.D.F. Selective oxidation of methane to synthesis gas using transition metal catalysts. Nature 1990, 344, 319-321. [CrossRef]

235. Hargreaves, J.S.J.; Hutchings, G.J.; Joyner, R.W. Control of product selectivity in the partial oxidation of methane. Nature 1990, 348, 428-429. [CrossRef]

236. Hickman, D.A.; Schmidt, L.D. Production of Syngas by Direct Catalytic Oxidation of Methane. Science 1993, 259, 343-346. [CrossRef]

237. Pino, L.; Recupero, V.; Beninati, S.; Shukla, A.K.; Hegde, M.S.; Bera, P. Catalytic partial-oxidation of methane on a ceria-supported platinum catalyst for application in fuel cell electric vehicles. Appl. Catal. A Gen. 2002, 225, 63-75. [CrossRef]

238. Tang, W.; Hu, Z.; Wang, M.; Stucky, G.D.; Metiu, H.; McFarland, E.W. Methane complete and partial oxidation catalyzed by Pt-doped $\mathrm{CeO}_{2}$. J. Catal. 2010, 273, 125-137. [CrossRef]

239. Gélin, P.; Primet, M. Complete oxidation of methane at low temperature over noble metal based catalysts: A review. Appl. Catal. B Environ. 2002, 39,1-37. [CrossRef]

240. Honkanen, M.; Kärkkäinen, M.; Viitanen, V.; Jiang, H.; Kallinen, K.; Huuhtanen, M.; Vippola, M.; Lahtinen, J.; Keiski, R.; Lepistö, T. Structural Characteristics of Natural-Gas-Vehicle-Aged Oxidation Catalyst. Top. Catal. 2013, 56, 576-585. [CrossRef]

241. Choudhary, T.V.; Banerjee, S.; Choudhary, V.R. Catalysts for combustion of methane and lower alkanes. Appl. Catal. A Gen. 2002, 234,1-23. [CrossRef]

242. Chen, J.; Arandiyan, H.; Gao, X.; Li, J. Recent Advances in Catalysts for Methane Combustion. Catal. Surv. Asia 2015, 19, 140-171. [CrossRef]

243. Farrauto, R.J. Low-Temperature Oxidation of Methane. Science 2012, 337, 659-660. [CrossRef]

244. Sekizawa, K.; Widjaja, H.; Maeda, S.; Ozawa, Y.; Eguchi, K. Low temperature oxidation of methane over Pd catalyst supported on metal oxides. Catal. Today 2000, 59, 69-74. [CrossRef]

245. Datye, A.K.; Bravo, J.; Nelson, T.R.; Atanasova, P.; Lyubovsky, M.; Pfefferle, L. Catalyst microstructure and methane oxidation reactivity during the $\mathrm{Pd} \leftrightarrow \mathrm{PdO}$ transformation on alumina supports. Appl. Catal. A Gen. 2000, 198, 179-196. [CrossRef]

246. Chin, Y.-H.; Buda, C.; Neurock, M.; Iglesia, E. Consequences of Metal-Oxide Interconversion for C-H Bond Activation during $\mathrm{CH}_{4}$ Reactions on Pd Catalysts. J. Am. Chem. Soc. 2013, 135, 15425-15442. [CrossRef]

247. Ramírez-López, R.; Elizalde-Martinez, I.; Balderas-Tapia, L. Complete catalytic oxidation of methane over $\mathrm{Pd} / \mathrm{CeO}_{2}-\mathrm{Al}_{2} \mathrm{O}_{3}$ : The influence of different ceria loading. Catal. Today 2010, 150, 358-362. [CrossRef]

248. Tippayawong, N.; Thanompongchart, P. Biogas quality upgrade by simultaneous removal of $\mathrm{CO}_{2}$ and $\mathrm{H}_{2} \mathrm{~S}$ in a packed column reactor. Energy 2010, 35, 4531-4535. [CrossRef]

249. Lavoie, J.M. Review on dry reforming of methane, a potentially more environmentally-friendly approach to the increasing natural gas exploitation. Front. Chem. 2014, 2, 1-17. [CrossRef]

250. Ghorbanzadeh, A.M.; Norouzi, S.; Mohammadi, T. High energy efficiency in syngas and hydrocarbon production from dissociation of $\mathrm{CH}_{4}-\mathrm{CO}_{2}$ mixture in a non-equilibrium pulsed plasma. J. Phys. D. Appl. Phys. 2005, 38, 3804-3811. [CrossRef]

251. Dry, M.E.; Steynberg, A.P. Chapter 5-Commercial FT Process Applications. In Fischer-Tropsch Technology; Steynberg, A., Dry, M., Eds.; Studies in Surface Science and Catalysis; Elsevier: Amsterdam, The Netherlands, 2004; pp. 406-481.

252. Wang, S.; Lu, G.Q.; Millar, G.J. Carbon dioxide reforming of methane to produce synthesis gas over metal-supported catalysts: State of the art. Energy Fuels 1996, 10, 896-904. [CrossRef]

253. Bradford, M.C.J.; Vannice, M.A. $\mathrm{CO}_{2}$ reforming of $\mathrm{CH}_{4}$. Catal. Rev. Sci. Eng. 1999, 41, 1-42. [CrossRef]

254. Rodhe, H. A Comparison of the Contribution of Various Gases to the Greenhouse Effect. Science 1990, 248, 1217-1219. [CrossRef]

255. Huang, A.; Xia, G.; Wang, J.; Suib, S.L.; Hayashi, Y.; Matsumoto, H. $\mathrm{CO}_{2}$ Reforming of $\mathrm{CH}_{4}$ by Atmospheric Pressure ac Discharge Plasmas. J. Catal. 2000, 189, 349-359. [CrossRef]

256. Wei, J.; Iglesia, E. Mechanism and Site Requirements for Activation and Chemical Conversion of Methane on Supported Pt Clusters and Turnover Rate Comparisons among Noble Metals. J. Phys. Chem. B 2004, 108, 4094-4103. [CrossRef]

257. Rostrupnielsen, J.R.; Hansen, J.H.B. $\mathrm{CO}_{2}$-Reforming of Methane over Transition Metals. J. Catal. 1993, 144, 38-49. [CrossRef] 
258. Hou, Z.; Chen, P.; Fang, H.; Zheng, X.; Yashima, T. Production of synthesis gas via methane reforming with $\mathrm{CO}_{2}$ on noble metals and small amount of noble-(Rh-) promoted Ni catalysts. Int. J. Hydrog. Energy 2006, 31, 555-561. [CrossRef]

259. Pakhare, D.; Spivey, J. A review of dry $\left(\mathrm{CO}_{2}\right)$ reforming of methane over noble metal catalysts. Chem. Soc. Rev. 2014, 43, 7813-7837. [CrossRef] [PubMed]

260. Bradford, M.C.J.; Vannice, M.A. Catalytic reforming of methane with carbon dioxide over nickel catalysts I. Catalyst characterization and activity. Appl. Catal. A Gen. 1996, 142, 73-96. [CrossRef]

261. Budiman, A.W.; Song, S.-H.; Chang, T.-S.; Shin, C.-H.; Choi, M.-J. Dry Reforming of Methane Over Cobalt Catalysts: A Literature Review of Catalyst Development. Catal. Surv. Asia 2012, 16, 183-197. [CrossRef]

262. Kim, D.K.; Stöwe, K.; Müller, F.; Maier, W.F. Mechanistic study of the unusual catalytic properties of a new NiCe mixed oxide for the $\mathrm{CO}_{2}$ reforming of methane. J. Catal. 2007, 247, 101-111. [CrossRef]

263. Wei, J.; Iglesia, E. Reaction Pathways and Site Requirements for the Activation and Chemical Conversion of Methane on Ru-Based Catalysts. J. Phys. Chem. B 2004, 108, 7253-7262. [CrossRef]

264. Mimura, N.; Takahara, I.; Inaba, M.; Okamoto, M.; Murata, K. High-performance Cr/H-ZSM-5 catalysts for oxidative dehydrogenation of ethane to ethylene with $\mathrm{CO}_{2}$ as an oxidant. Catal. Commun. 2002, 3, 257-262. [CrossRef]

265. Porosoff, M.D.; Myint, M.N.Z.; Kattel, S.; Xie, Z.; Gomez, E.; Liu, P.; Chen, J.G. Identifying Different Types of Catalysts for $\mathrm{CO}_{2}$ Reduction by Ethane through Dry Reforming and Oxidative Dehydrogenation. Angew. Chem. Int. Ed. 2015, 54, 15501-15505. [CrossRef]

266. Huber, G.W.; Iborra, S.; Corma, A. Synthesis of Transportation Fuels from Biomass: Chemistry, Catalysts, and Engineering. Chem. Rev. 2006, 106, 4044-4098. [CrossRef]

267. Mattos, L.V.; Jacobs, G.; Davis, B.H.; Noronha, F.B. Production of Hydrogen from Ethanol: Review of Reaction Mechanism and Catalyst Deactivation. Chem. Rev. 2012, 112, 4094-4123. [CrossRef]

268. Banach, B.; Machocki, A.; Rybak, P.; Denis, A.; Grzegorczyk, W.; Gac, W. Selective production of hydrogen by steam reforming of bio-ethanol. Catal. Today 2011, 176, 28-35. [CrossRef]

269. Breen, J.P.; Burch, R.; Coleman, H.M. Metal-catalysed steam reforming of ethanol in the production of hydrogen for fuel cell applications. Appl. Catal. B Environ. 2002, 39, 65-74. [CrossRef]

270. Liguras, D.K.; Kondarides, D.I.; Verykios, X.E. Production of hydrogen for fuel cells by steam reforming of ethanol over supported noble metal catalysts. Appl. Catal. B Environ. 2003, 43, 345-354. [CrossRef]

271. Frusteri, F.; Freni, S.; Spadaro, L.; Chiodo, V.; Bonura, G.; Donato, S.; Cavallaro, S. $\mathrm{H}_{2}$ production for MC fuel cell by steam reforming of ethanol over $\mathrm{MgO}$ supported $\mathrm{Pd}, \mathrm{Rh}, \mathrm{Ni}$ and Co catalysts. Catal. Commun. 2004, 5, 611-615. [CrossRef]

272. Ni, M.; Leung, D.Y.C.; Leung, M.K.H. A review on reforming bio-ethanol for hydrogen production. Int. J. Hydrog. Energy 2007, 32, 3238-3247. [CrossRef]

273. Scott, M.; Goeffroy, M.; Chiu, W.; Blackford, M.A.; Idriss, H. Hydrogen Production from Ethanol over Rh-Pd/CeO 2 Catalysts. Top. Catal. 2008, 51, 13-21. [CrossRef]

274. Contreras, J.L.; Salmones, J.; Colín-Luna, J.A.; Nuño, L.; Quintana, B.; Córdova, I.; Zeifert, B.; Tapia, C.; Fuentes, G.A. Catalysts for $\mathrm{H}_{2}$ production using the ethanol steam reforming (a review). Int. J. Hydrog. Energy 2014, 39, 18835-18853. [CrossRef]

275. Mariño, F.J.; Cerrella, E.G.; Duhalde, S.; Jobbagy, M.; Laborde, M.A. Hydrogen from steam reforming of ethanol. characterization and performance of copper-nickel supported catalysts. Int. J. Hydrog. Energy 1998, 23, 1095-1101. [CrossRef]

276. Llorca, J.; Homs, N.; Sales, J.; De la Piscina, P.R. Efficient Production of Hydrogen over Supported Cobalt Catalysts from Ethanol Steam Reforming. J. Catal. 2002, 209, 306-317. [CrossRef]

277. Zhang, B.; Tang, X.; Li, Y.; Cai, W.; Xu, Y.; Shen, W. Steam reforming of bio-ethanol for the production of hydrogen over ceria-supported Co, Ir and Ni catalysts. Catal. Commun. 2006, 7, 367-372. [CrossRef]

278. Denis, A.; Grzegorczyk, W.; Gac, W.; Machocki, A. Steam reforming of ethanol over Ni/support catalysts for generation of hydrogen for fuel cell applications. Catal. Today 2008, 137, 453-459. [CrossRef]

279. Bayram, B.; Soykal, I.I.; Von Deak, D.; Miller, J.T.; Ozkan, U.S. Ethanol steam reforming over Co-based catalysts: Investigation of cobalt coordination environment under reaction conditions. J. Catal. 2011, 284, 77-89. [CrossRef] 
280. Dan, M.; Mihet, M.; Tasnadi-Asztalos, Z.; Imre-Lucaci, A.; Katona, G.; Lazar, M.D. Hydrogen production by ethanol steam reforming on nickel catalysts: Effect of support modification by $\mathrm{CeO}_{2}$ and $\mathrm{La}_{2} \mathrm{O}_{3}$. Fuel 2015, 147, 260-268. [CrossRef]

281. Laosiripojana, N.; Assabumrungrat, S. Catalytic steam reforming of ethanol over high surface area $\mathrm{CeO}_{2}$ : The role of $\mathrm{CeO}_{2}$ as an internal pre-reforming catalyst. Appl. Catal. B Environ. 2006, 66, 29-39. [CrossRef]

282. Lin, S.S.-Y.; Kim, D.H.; Ha, S.Y. Metallic phases of cobalt-based catalysts in ethanol steam reforming: The effect of cerium oxide. Appl. Catal. A Gen. 2009, 355, 69-77. [CrossRef]

283. Virginie, M.; Araque, M.; Roger, A.-C.; Vargas, J.C.; Kiennemann, A. Comparative study of $\mathrm{H}_{2}$ production by ethanol steam reforming on $\mathrm{Ce}_{2} \mathrm{Zr}_{1.5} \mathrm{Co}_{0.5} \mathrm{O}_{8-\delta}$ and $\mathrm{Ce}_{2} \mathrm{Zr}_{1.5} \mathrm{Co}_{0.47} \mathrm{Rh}_{0.07} \mathrm{O}_{8-\delta}$ : Evidence of the $\mathrm{Rh}$ role on the deactivation process. Catal. Today 2008, 138, 21-27. [CrossRef]

284. Llorca, J.; Ramírez de la Piscina, P.; Dalmon, J.-A.; Homs, N. Transformation of $\mathrm{Co}_{3} \mathrm{O}_{4}$ during Ethanol Steam-Re-forming. Activation Process for Hydrogen Production. Chem. Mater. 2004, 16, 3573-3578. [CrossRef]

285. Raskó, J.; Dömök, M.; Baán, K.; Erdőhelyi, A. FTIR and mass spectrometric study of the interaction of ethanol and ethanol-water with oxide-supported platinum catalysts. Appl. Catal. A Gen. 2006, 299, $202-211$. [CrossRef]

286. Palo, D.R.; Dagle, R.A.; Holladay, J.D. Methanol Steam Reforming for Hydrogen Production. Chem. Rev. 2007, 107, 3992-4021. [CrossRef]

287. Peppley, B.A.; Amphlett, J.C.; Kearns, L.M.; Mann, R.F. Methanol-steam reforming on Cu/ZnO/ $\mathrm{Al}_{2} \mathrm{O}_{3}$. Part 1: The reaction network. Appl. Catal. A Gen. 1999, 179, 21-29. [CrossRef]

288. Lee, J.K.; Ko, J.B.; Kim, D.H. Methanol steam reforming over $\mathrm{Cu} / \mathrm{ZnO} / \mathrm{Al}_{2} \mathrm{O}_{3}$ catalyst: Kinetics and effectiveness factor. Appl. Catal. A Gen. 2004, 278, 25-35. [CrossRef]


prepared by homogeneous precipitation method in steam reforming of methanol. Appl. Catal. A Gen. 2004, 263, 249-253. [CrossRef]

290. Laosiripojana, N.; Assabumrungrat, S. Catalytic steam reforming of methane, methanol, and ethanol over Ni/YSZ: The possible use of these fuels in internal reforming SOFC. J. Power Sources 2007, 163, 943-951. [CrossRef]

291. Lu, J.; Li, X.; He, S.; Han, C.; Wan, G.; Lei, Y.; Chen, R.; Liu, P.; Chen, K.; Zhang, L.; et al. Hydrogen production via methanol steam reforming over Ni-based catalysts: Influences of Lanthanum (La) addition and supports. Int. J. Hydrog. Energy 2017, 42, 3647-3657. [CrossRef]

292. Tatibouët, J.M. Methanol oxidation as a catalytic surface probe. Appl. Catal. A Gen. 1997, 148, $213-252$. [CrossRef]

293. Vilé, G.; Bridier, B.; Wichert, J.; Pérez-Ramírez, J. Ceria in Hydrogenation Catalysis: High Selectivity in the Conversion of Alkynes to Olefins. Angew. Chem. Int. Ed. 2012, 51, 8620-8623. [CrossRef] [PubMed]

294. Vilé, G.; Colussi, S.; Krumeich, F.; Trovarelli, A.; Pérez-Ramírez, J. Opposite Face Sensitivity of $\mathrm{CeO}_{2}$ in Hydrogenation and Oxidation Catalysis. Angew. Chem. Int. Ed. 2014, 53, 12069-12072. [CrossRef]

295. Sohlberg, K.; Pantelides, S.T.; Pennycook, S.J. Interactions of Hydrogen with $\mathrm{CeO}_{2}$. J. Am. Chem. Soc. 2001, 123, 6609-6611. [CrossRef]

296. Watkins, M.B.; Foster, A.S.; Shluger, A.L. Hydrogen Cycle on $\mathrm{CeO}_{2}$ (111) Surfaces: Density Functional Theory Calculations. J. Phys. Chem. C 2007, 111, 15337-15341. [CrossRef]

297. Brisse, A.; Schefold, J.; Zahid, M. High temperature water electrolysis in solid oxide cells. Int. J. Hydrog. Energy 2008, 33, 5375-5382. [CrossRef]

298. Laguna-Bercero, M.A. Recent advances in high temperature electrolysis using solid oxide fuel cells: A review. J. Power Sources 2012, 203, 4-16. [CrossRef]

299. El Gabaly, F.; Grass, M.; McDaniel, A.H.; Farrow, R.L.; Linne, M.A.; Hussain, Z.; Bluhm, H.; Liu, Z.; McCarty, K.F. Measuring individual overpotentials in an operating solid-oxide electrochemical cell. Phys. Chem. Chem. Phys. 2010, 12, 12138-12145. [CrossRef] [PubMed]

300. DeCaluwe, S.C.; Grass, M.E.; Zhang, C.; Gabaly, F.E.; Bluhm, H.; Liu, Z.; Jackson, G.S.; McDaniel, A.H.; McCarty, K.F.; Farrow, R.L.; et al. In situ characterization of ceria oxidation states in high-temperature electrochemical cells with ambient pressure XPS. J. Phys. Chem. C 2010, 114, 19853-19861. [CrossRef]

301. Crumlin, E.J.; Bluhm, H.; Liu, Z. In situ investigation of electrochemical devices using ambient pressure photoelectron spectroscopy. J. Electron. Spectros. Relat. Phenom. 2013, 190, 84-92. [CrossRef] 
302. Stoerzinger, K.A.; Hong, W.T.; Crumlin, E.J.; Bluhm, H.; Shao-Horn, Y. Insights into Electrochemical Reactions from Ambient Pressure Photoelectron Spectroscopy. Acc. Chem. Res. 2015, 48, 2976-2983. [CrossRef] [PubMed]

303. Yu, Y.; Mao, B.; Geller, A.; Chang, R.; Gaskell, K.; Eichhorn, B.W. $\mathrm{CO}_{2}$ activation and carbonate intermediates: An operando AP-XPS study of $\mathrm{CO}_{2}$ electrolysis reactions on solid oxide electrochemical cells. Phys. Chem. Chem. Phys. 2014, 16, 11633-11639. [CrossRef]

304. Jacobson, A.J. Materials for solid oxide fuel cells. Chem. Mater. 2010, 22, 660-674. [CrossRef]

305. Orera, A.; Slater, P.R. New chemical systems for solid oxide fuel cells. Chem. Mater. 2010, 22, 675-690. [CrossRef]

306. Rafique, M.; Nawaz, H.; Rafique, M.S.; Tahir, M.B.; Nabi, G.; Khalid, N.R. Material and method selection for efficient solid oxide fuel cell anode: Recent advancements and reviews. Int. J. Energy Res. 2019, 43, 2423-2446. [CrossRef]

307. Haile, S.M. Fuel cell materials and components. Acta Mater. 2003, 51, 5981-6000. [CrossRef]

308. Kharton, V.V.; Figueiredo, F.M.; Navarro, L.; Naumovich, E.N.; Kovalevsky, A.V.; Yaremchenko, A.A.; Viskup, A.P.; Carneiro, A.; Marques, F.M.B.; Frade, J.R. Ceria-based materials for solid oxide fuel cells. J. Mater. Sci. 2001, 36, 1105-1117. [CrossRef]

309. Zhang, C.; Grass, M.E.; McDaniel, A.H.; Decaluwe, S.C.; El Gabaly, F.; Liu, Z.; McCarty, K.F.; Farrow, R.L.; Linne, M.A.; Hussain, Z.; et al. Measuring fundamental properties in operating solid oxide electrochemical cells by using in situ X-ray photoelectron spectroscopy. Nat. Mater. 2010, 9, 944-949. [CrossRef] [PubMed]

310. Zhang, C.; Grass, M.E.; Yu, Y.; Gaskell, K.J.; Decaluwe, S.C.; Chang, R.; Jackson, G.S.; Hussain, Z.; Bluhm, H.; Eichhorn, B.W.; et al. Multielement activity mapping and potential mapping in solid oxide electrochemical cells through the use of operando XPS. ACS Catal. 2012, 2, 2297-2304. [CrossRef]

311. Chueh, W.C.; Mcdaniel, A.H.; Grass, M.E.; Hao, Y.; Jabeen, N.; Liu, Z.; Haile, S.M.; Mccarty, K.F.; Bluhm, H.; El Gabaly, F. Highly Enhanced Concentration and Stability of Reactive $\mathrm{Ce}^{3+}$ on Doped $\mathrm{CeO}_{2}$ Surface Revealed In Operando. Chem. Mater. 2012, 24, 1876-1882. [CrossRef]

312. Zhang, C.; Yu, Y.; Grass, M.E.; Dejoie, C.; Ding, W.; Gaskell, K.; Jabeen, N.; Hong, Y.P.; Shavorskiy, A.; Bluhm, H.; et al. Mechanistic studies of water electrolysis and hydrogen electro-oxidation on high temperature ceria-based solid oxide electrochemical cells. J. Am. Chem. Soc. 2013, 135, 11572-11579. [CrossRef]

313. Gopal, C.B.; El Gabaly, F.; McDaniel, A.H.; Chueh, W.C. Origin and Tunability of Unusually Large Surface Capacitance in Doped Cerium Oxide Studied by Ambient-Pressure X-Ray Photoelectron Spectroscopy. Adv. Mater. 2016, 28, 4692-4697. [CrossRef]

314. Papaefthimiou, V.; Niakolas, D.K.; Paloukis, F.; Dintzer, T.; Zafeiratos, S. Is Steam an Oxidant or a Reductant for Nickel/Doped-Ceria Cermets? ChemPhysChem 2017, 18, 164-170. [CrossRef]

315. Papaefthimiou, V.; Niakolas, D.K.; Paloukis, F.; Teschner, D.; Knop-Gericke, A.; Haevecker, M.; Zafeiratos, S. Operando observation of nickel/ceria electrode surfaces during intermediate temperature steam electrolysis. J. Catal. 2017, 352, 305-313. [CrossRef]

316. Nurk, G.; Kooser, K.; Urpelainen, S.; Käämbre, T.; Joost, U.; Kodu, M.; Kivi, I.; Kanarbik, R.; Kukk, E.; Lust, E. Near ambient pressure X-ray photoelectron-and impedance spectroscopy study of $\mathrm{NiO}-\mathrm{Ce}_{0.9} \mathrm{Gd}_{0.1} \mathrm{O}_{2-\Delta}$ anode reduction using a novel dual-chamber spectroelectrochemical cell. J. Power Sources 2018, 378, 589-596. [CrossRef]

317. Wang, L.; Jackson, G.S. Evaluating the behavior of $\mathrm{CO} / \mathrm{CO}_{2}$ in Ni/GDC solid oxide fuel cell anodes. ECS Trans. 2015, 68, 1193-1205. [CrossRef]

318. Papaefthimiou, V.; Shishkin, M.; Niakolas, D.K.; Athanasiou, M.; Law, Y.T.; Arrigo, R.; Teschner, D.; Hävecker, M.; Knop-Gericke, A.; Schlögl, R.; et al. On the active surface state of nickel-ceria solid oxide fuel cell anodes during methane electrooxidation. Adv. Energy Mater. 2013, 3, 762-769. [CrossRef]

319. Graves, C.; Ebbesen, S.D.; Mogensen, M.; Lackner, K.S. Sustainable hydrocarbon fuels by recycling $\mathrm{CO}_{2}$ and $\mathrm{H}_{2} \mathrm{O}$ with renewable or nuclear energy. Renew. Sustain. Energy Rev. 2011, 15, 1-23. [CrossRef]

320. Sridhar, K.R.; Vaniman, B.T. Oxygen production on Mars using solid oxide electrolysis. Solid State Ion. 1997, 93, 321-328. [CrossRef]

(C) 2020 by the authors. Licensee MDPI, Basel, Switzerland. This article is an open access article distributed under the terms and conditions of the Creative Commons Attribution (CC BY) license (http://creativecommons.org/licenses/by/4.0/). 